\title{
الأهمية الاقتصادية لمدينة القدس الشريف في العهد العثماني
}

$($ ( $1918-1017)$

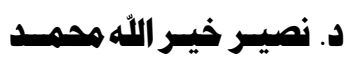

أستاذ مساع بقسم التاريخ- كلية الآداب

جامعة تكريت / العرلق

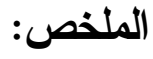$$
\text { الحمد الله وحده والصلاة وإلسلام على من لا نبي بعده، }
$$

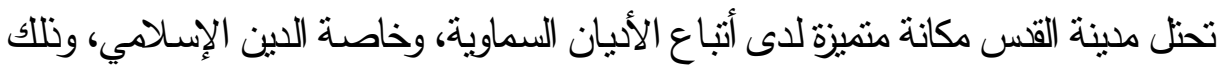

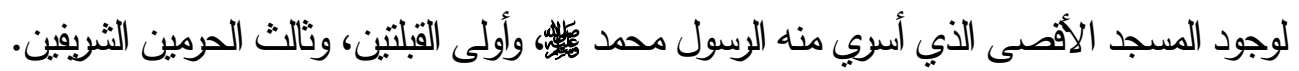

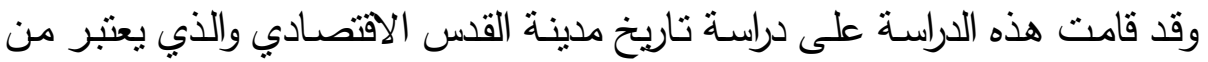
الأهمية بمكان، وظلك لما حباها الله من خيرات، إذا احتوت على خيرات كثيرة جعلها تعتمد

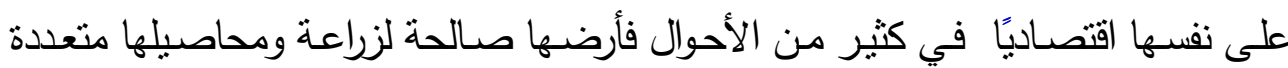

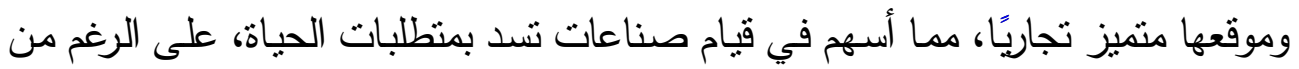
كونها بسيطة، إلاّ إنها سدت الحاجة في كثير من من الأحيان.

\section{Abstract}

ise be to God alone, and prayers and peace be upon the one after whom there is no prophet.

This study addressed the topic: The economic importance of the Holy City of Jerusalem in the Ottoman period.

The city of Jerusalem occupies a distinguished place among the followers of divine religions, especially the Islamic religion, due to the presence of the Al-Aqsa Mosque from which the Prophet Muhammad was held captive $\rho$, the first of the two qiblah, and the third of the Two Holy Mosques.

This study was based on studying the economic history of the city of Jerusalem, which is of great importance, because of God's blessings of goodness, if it contains many good things that made it depend on itself economically in many cases. Industries that meet the requirements of life, although they are simple, but they often meet the need. 


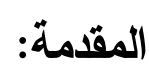

تحتل مدينـة القدس مكانـة مهرـة في نفوس المسلمين جميعًا وبـاقي أتبـاع الديانات

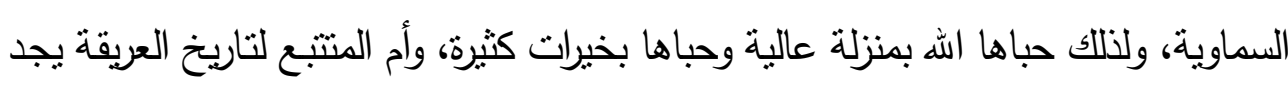

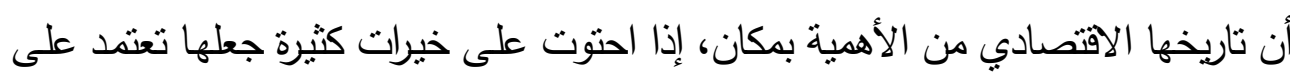

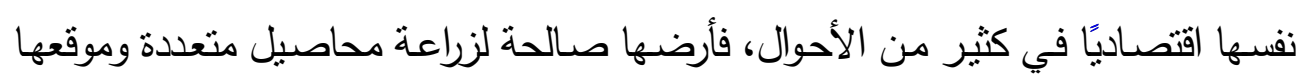

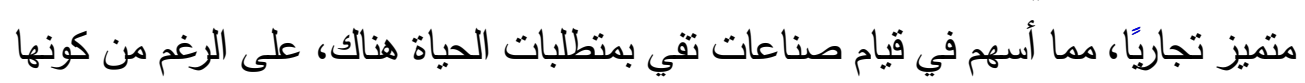
بسيطة إلاّ إنها سدت الحاجة في كثير من الأحيان.

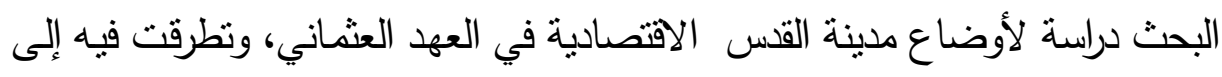

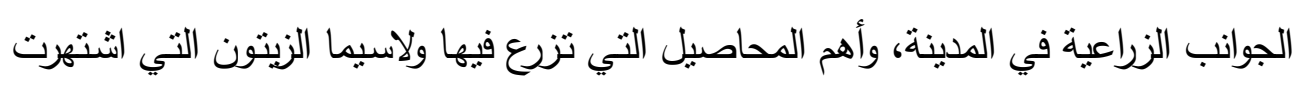

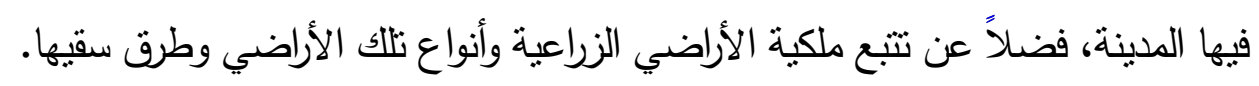

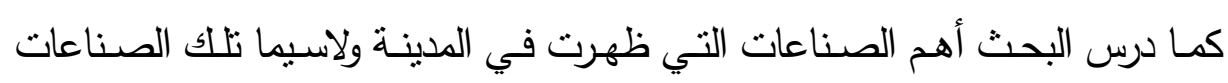
الحرفية التي تخل في الطقوس الدينية لمختلف الطوائف كالثموع والبخور والملابس وغيرها من الحرف والصناعات التي اشتهرت بها المدينة.

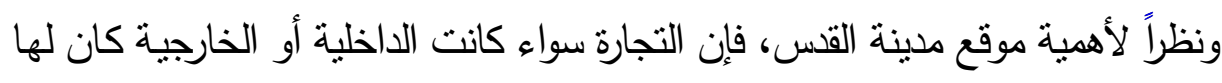

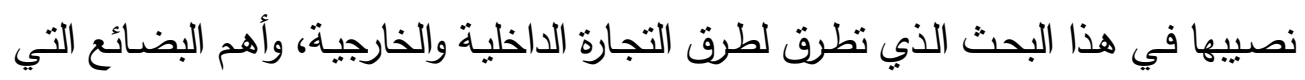

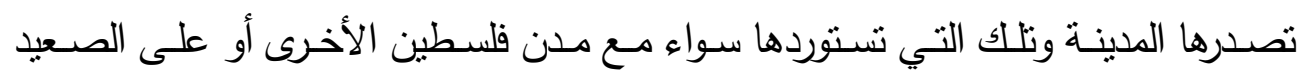
الخارجي مع الدول والبلدان المجاورة والبعيدة.

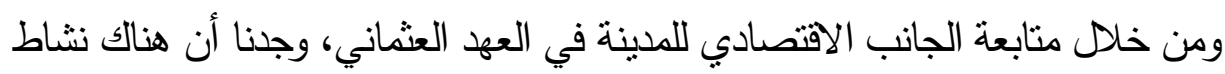

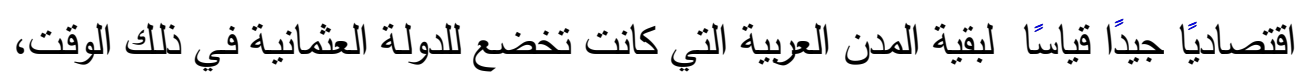

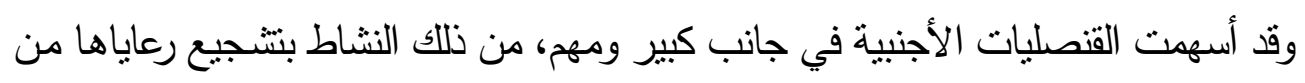

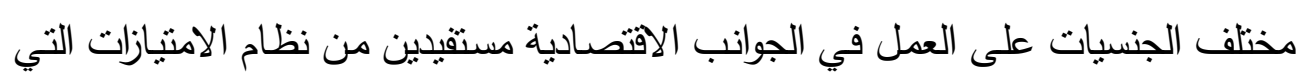
منحته الدولة العثمانية لرعايا الدول ولاسيما الأوروبية منها.

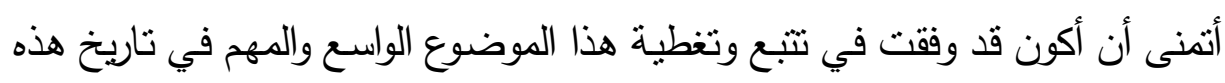
المدينة العريقة، والهه ولي التوفيق. 


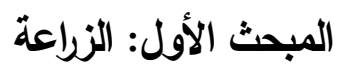

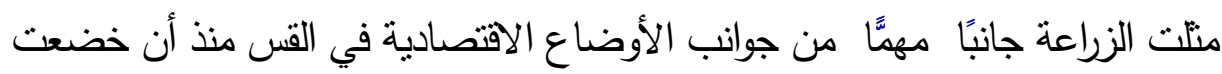

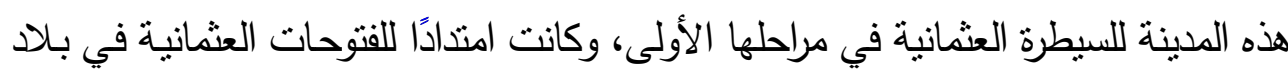

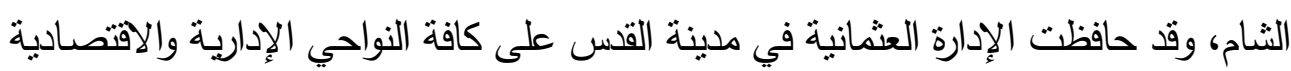

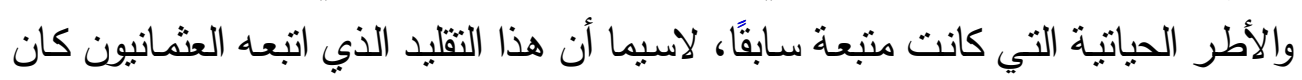

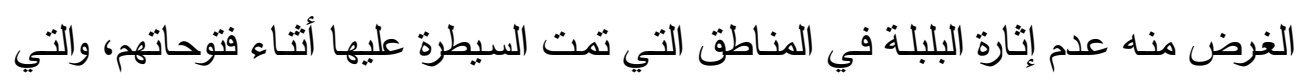
يمكن أن ينتج عنها انتشار الفوضى والاضطرابات (1).

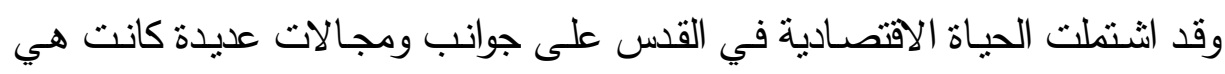

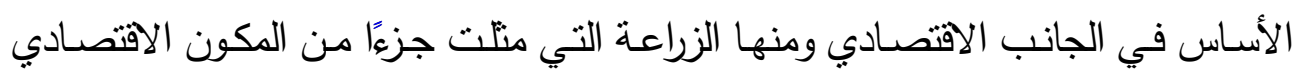

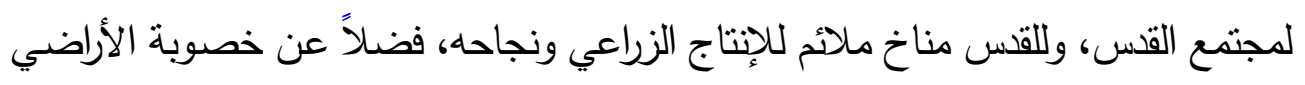

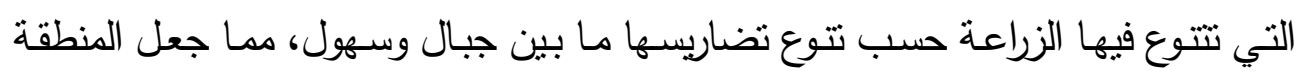

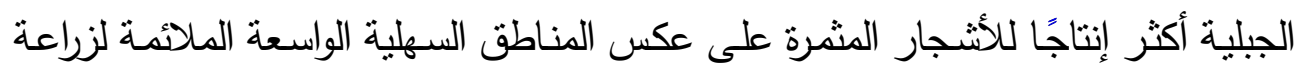
المحاصيل الأخرى كالحبوب وغيرها (r). وفيما يخص الأراضي الزراعية كان العثمانيون يقومون بإجراء عمليات واسعة وشاملة

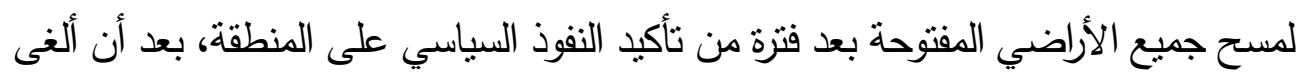

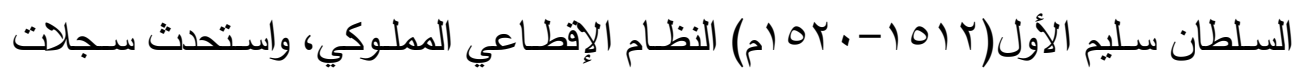

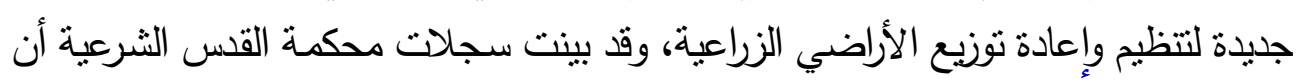

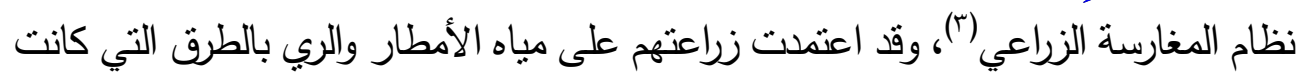
مستخدمة آنذاك وأهمها الآبار (๕).

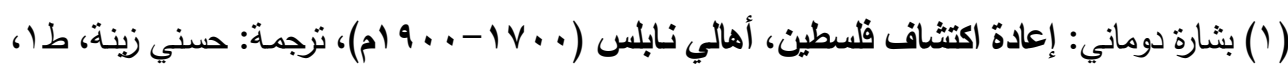

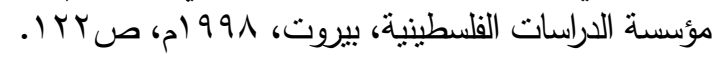

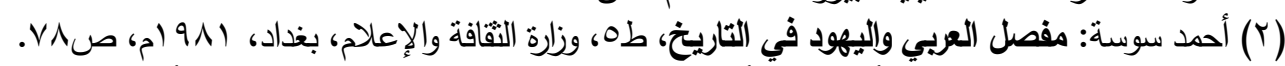

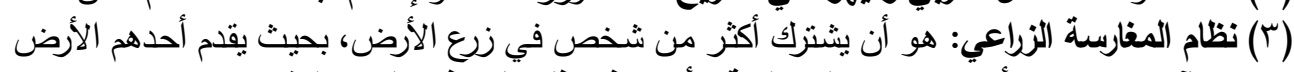

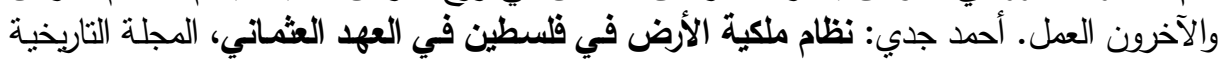

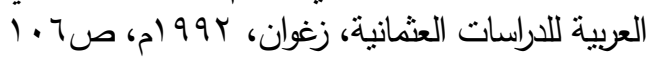

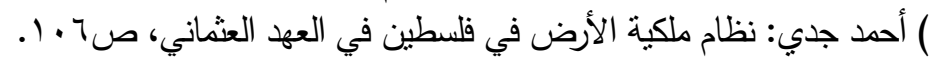




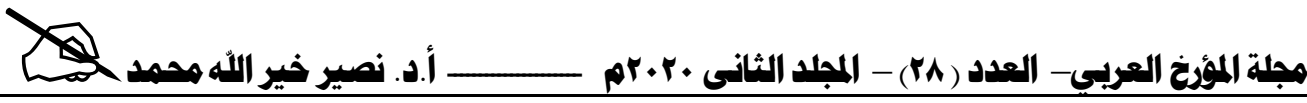

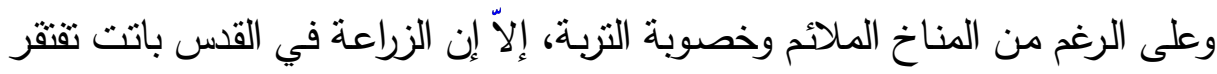

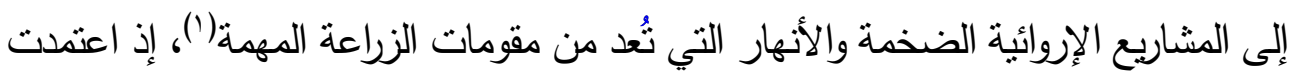

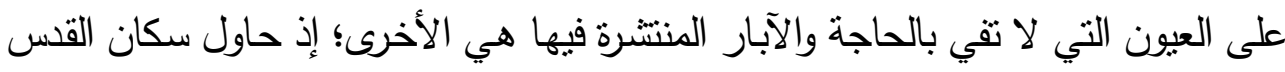

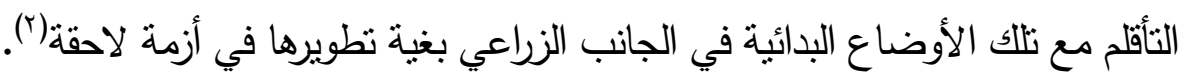

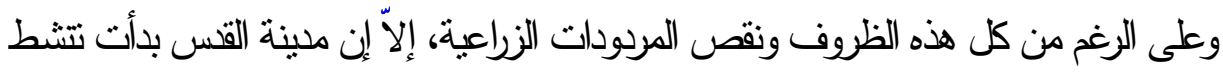

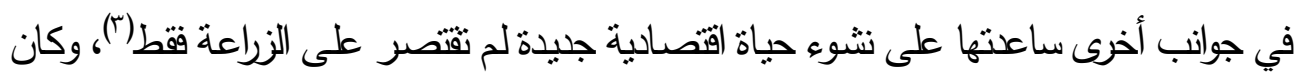
مناخ البحر المنوسط له الأثر الواضح على القس الثريف لتعرضه إلى رياح عكسية غريبة في

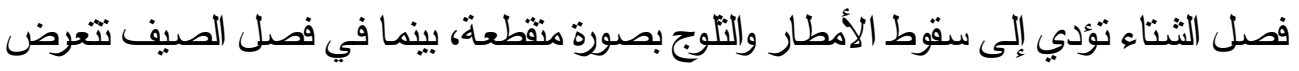

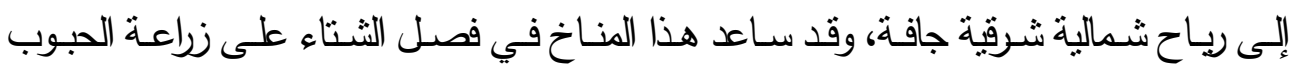

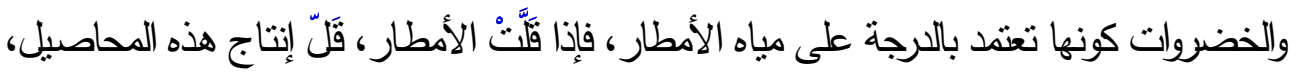

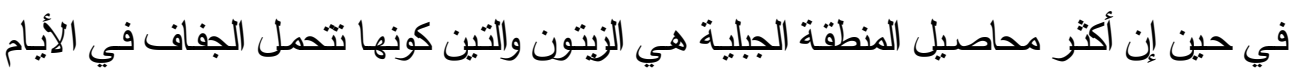

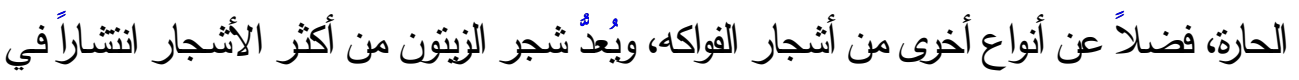

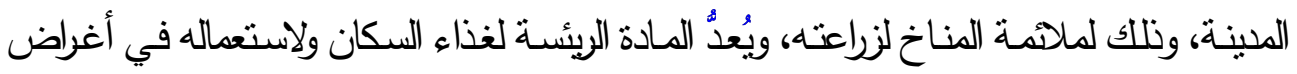

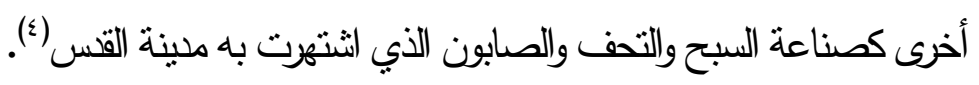

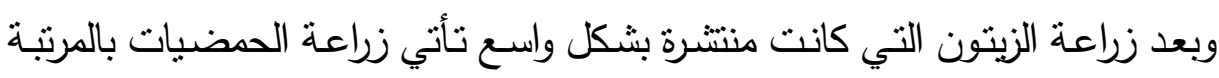

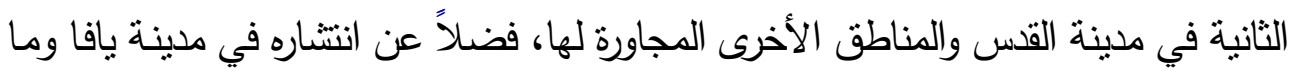

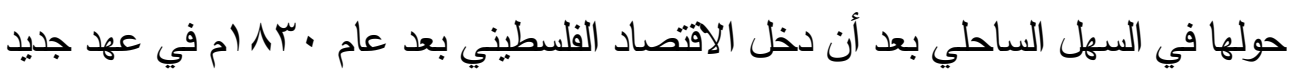

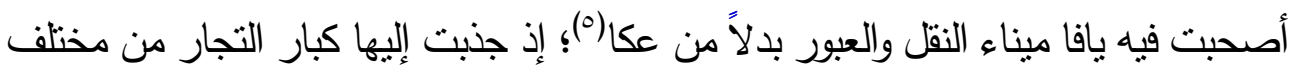

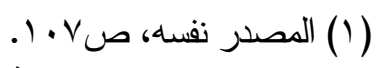

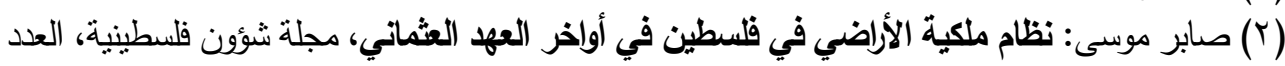

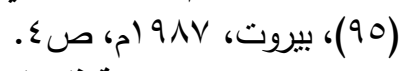

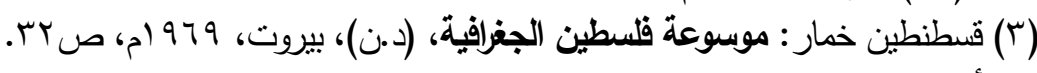

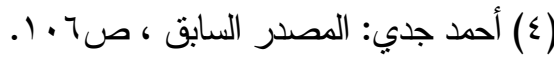
(0) محمد جميل بيهم: الحلقة المفقودة في تاريخ العرب، طا، مطبعة مصطفى البابي الحلبي، القاهرة، 


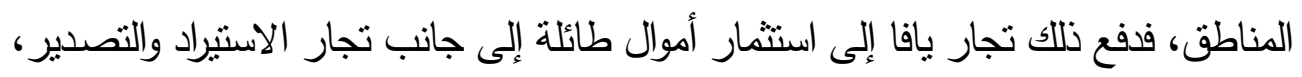

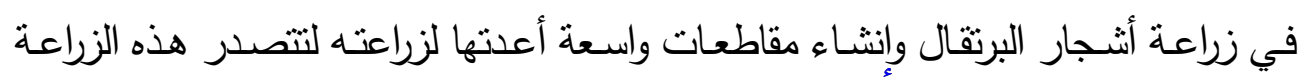
الاقتصاد الفلسطيني ('). وفي عام • AVV م، اسنطاعت مدينـة يافا من تصدير كميات كبيرة من محصول

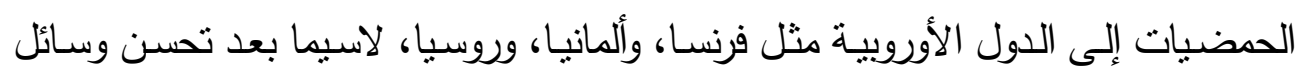

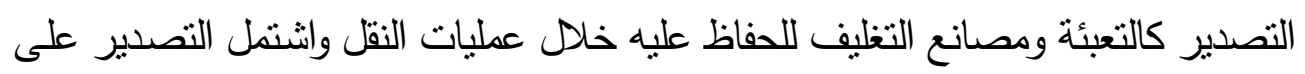
نوعية معينة من الحمضيات ذات القثرة السميكة لتحملها مسافات طويلة أكثر من غيرها كالبرتقال المحلي وهو أصغر حجمًا والذي يستهلاك في الأسواق المحلية الداخلية(؟).

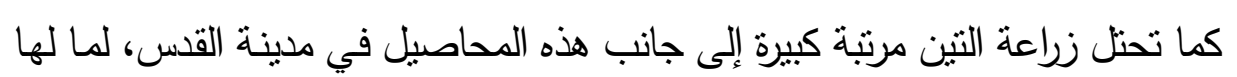

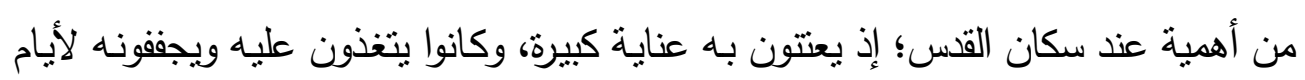

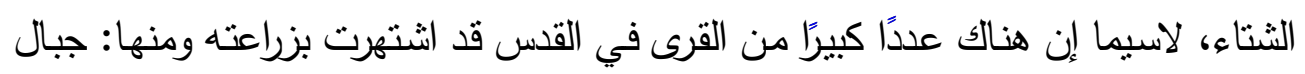

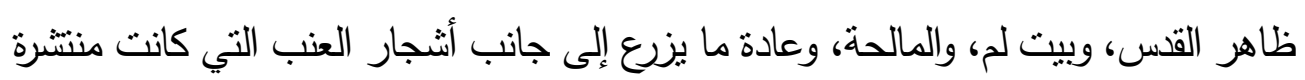

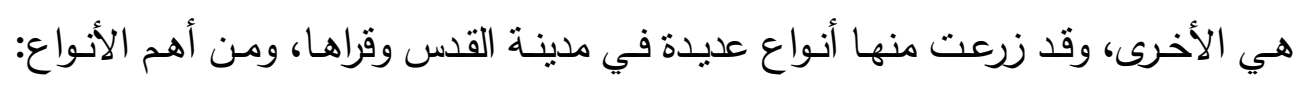

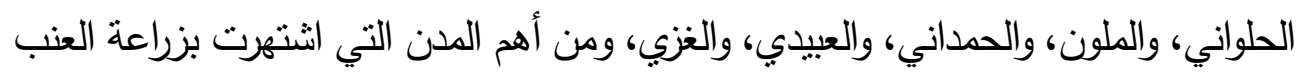

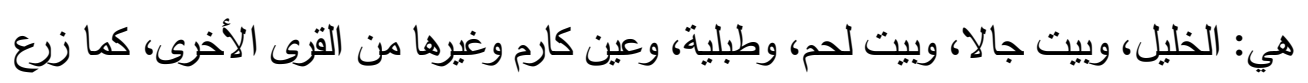

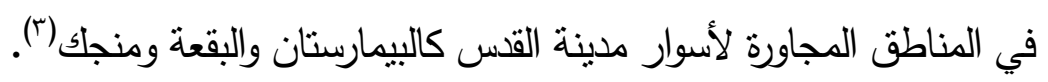

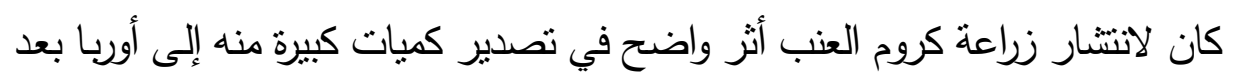

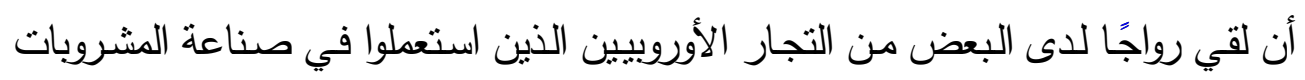

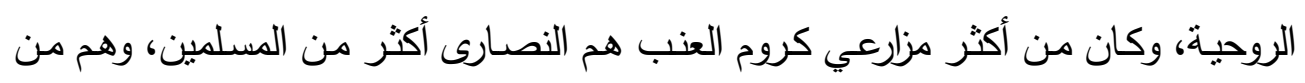

( (1) إبراهيم أبو رميس: الززاعة في القس وكراها في القرن التاسع عثر ، الهؤتنر الدولي التاسع لتناريخ بلاد

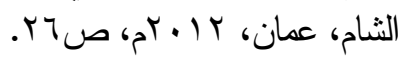

(r) محمود يزيك: برتقال يافا وأثره في التغيرات الاجتماعية والأتصادية في مدينة يافا ومحيطها في القرن

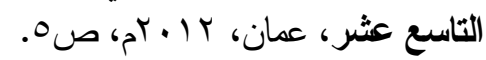

(Y) الصدر نفسه، صזَ" 


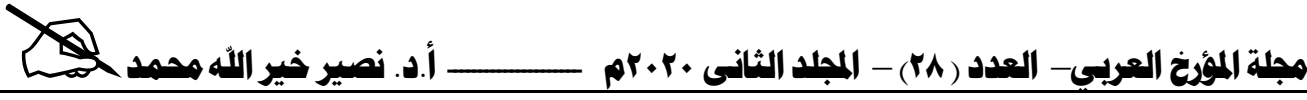

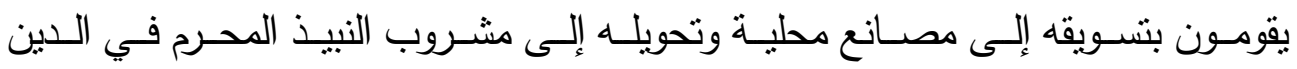

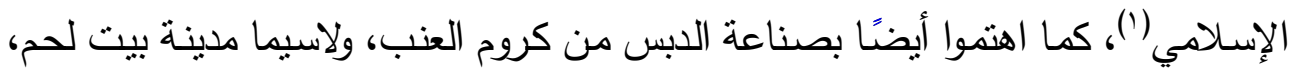

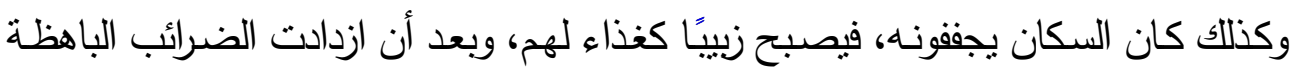

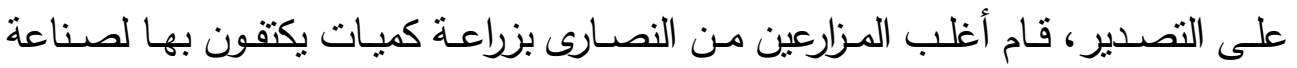

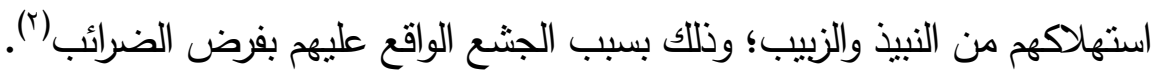

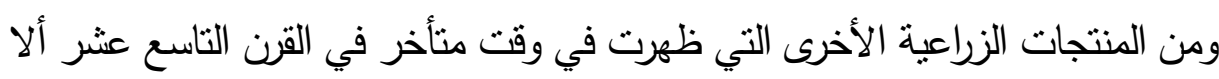

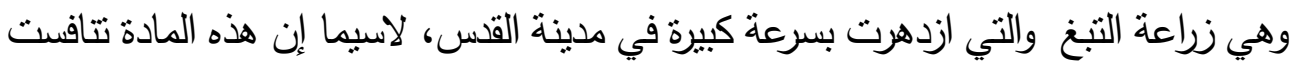

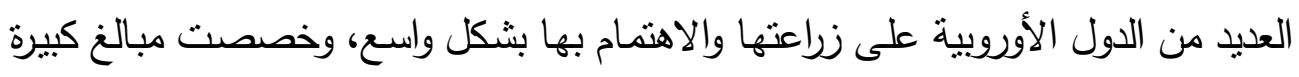

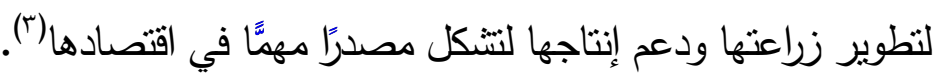

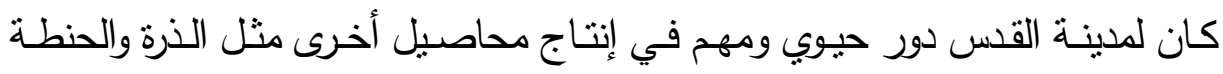

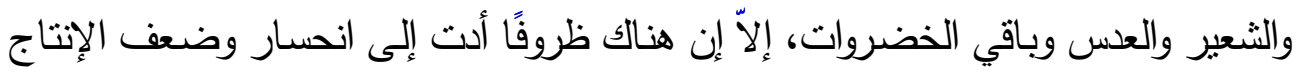

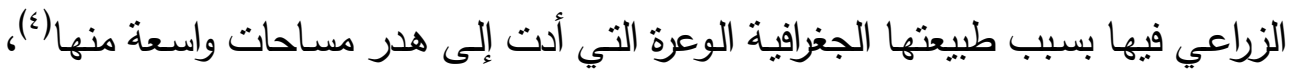

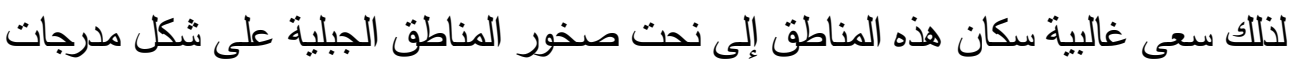

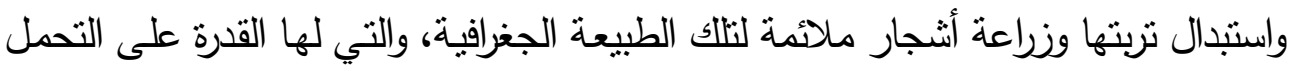

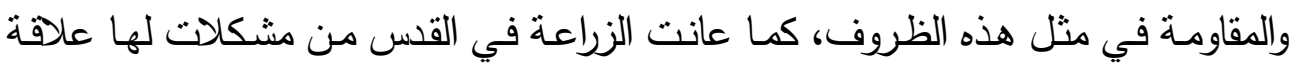

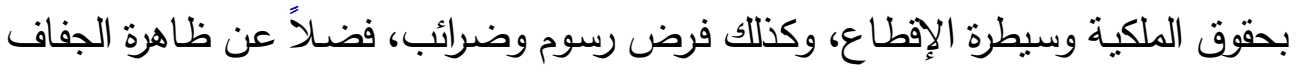

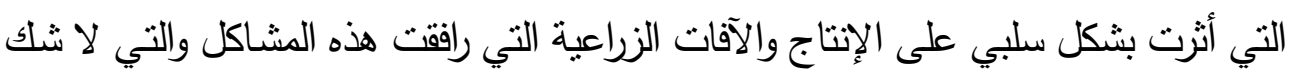

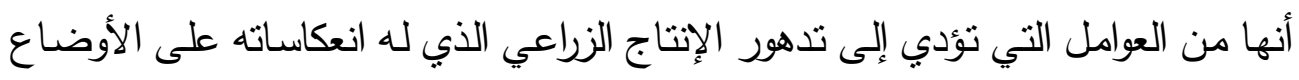

الاقتصادية بالقدس (o).

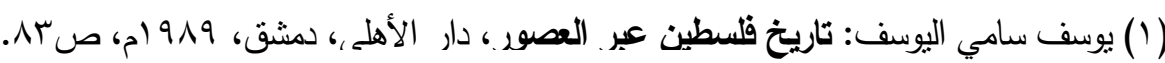

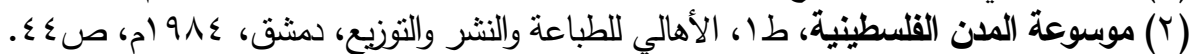

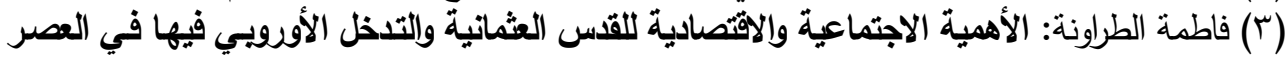

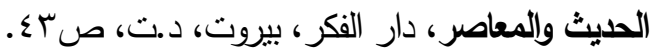




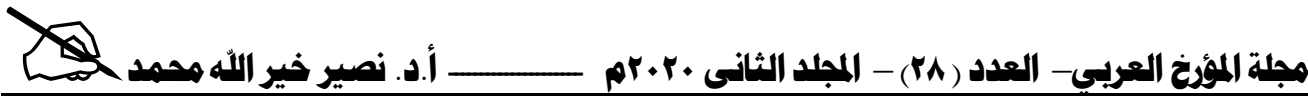

ساهمت مدينة القد، لاسيما المناطق السـلية المنبسطة في زراعة محاصيل مهمة بالنسبة للسكان وأهمها الحنطة والثعير ، والذي يعتمدان في زراعتهما على مياه الأمطار ، إذ إذهاء

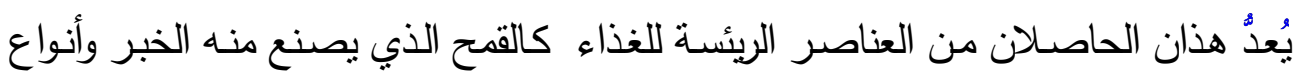
أخرى من الحلويات، وكنلك الثعير الذي انتشرت زراعته في مناطق واسعة، ومن أهم هذه المناطق: قلندية، وبيت سوريك، وصور ، وبيت سامور ، والمالحة، وأريحا ('). ومن الملاحظ بأن الاهتمام المتزايد من قبل السكان بزراعة هذه المحاصيل يعود إلى وهلى اعتمادهم الرئيسى عليهم في غذائهم وغذاء ماشيتهم، وبما إن هذه الزراعة تعتمد بالدرجة

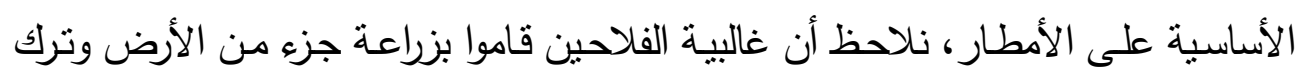
الجزء الآخر إلى السنة القامة؛ وذلك بسبب عدم وجود الإمكانيات من تغطية هذه المساحات

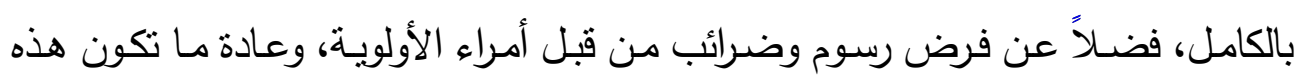
الضرائب باهظة أحيانًا في بعض مواسم الزراعة، وحسب إنتاج هذه الأراضي للمحاصيل (Y)؛

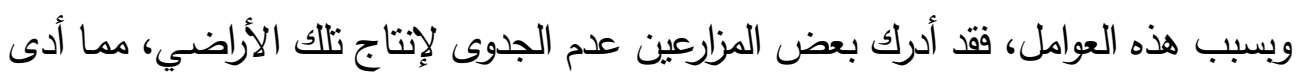
إلى هجرة بعضهم إلى مناطق قد تكون أفضل في مواسم أخرى (). ومن المحاصيل الأخرى التي اهتم سكان المدينة بزراعتها هو الفول والعس والفاصوليا

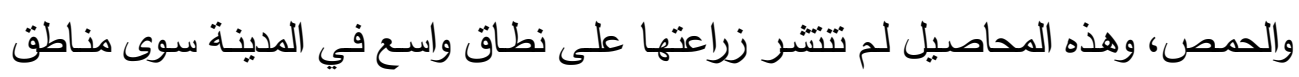
محددة ومنها: العيسلوية، وقرى كفر عانة، وجيعة، والرام، وبيت دجن، وعناتة، ولم يكتف رونف

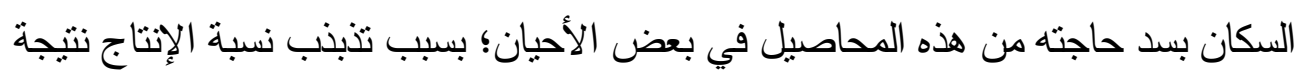

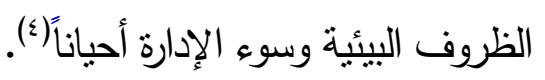

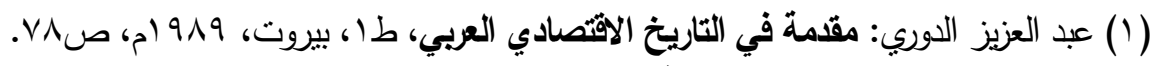

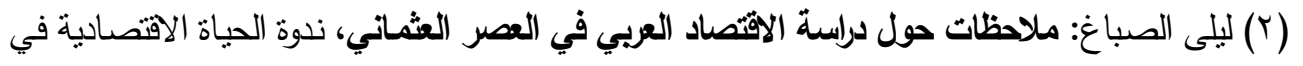

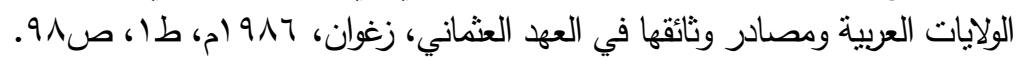

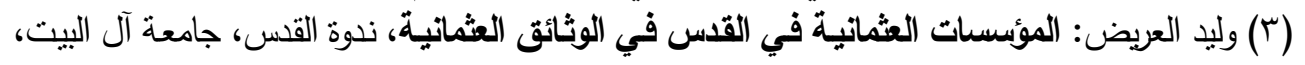

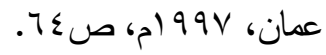

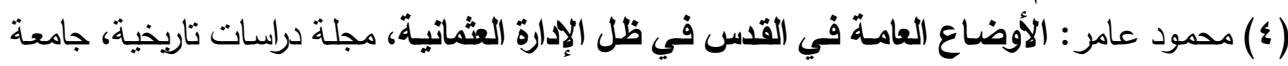

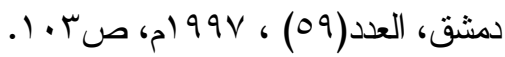




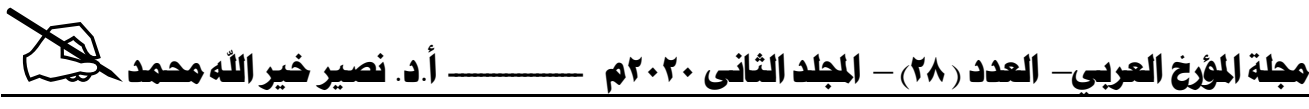

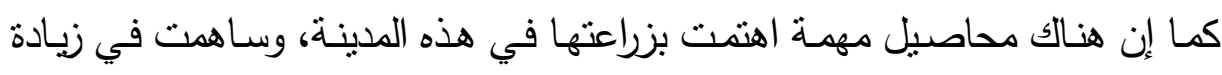
الدخل الوارد إليها، ألا وهي محصول القطن الذي كان من أجود الأنواع والذب ينت تصديره

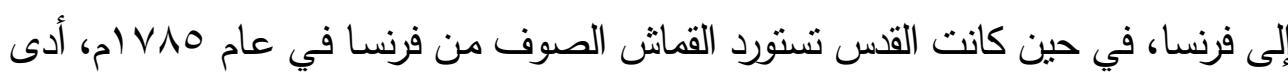

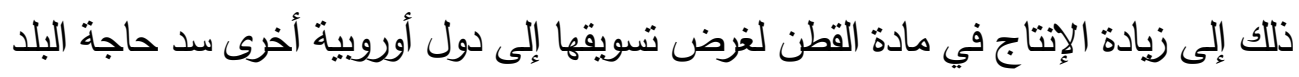

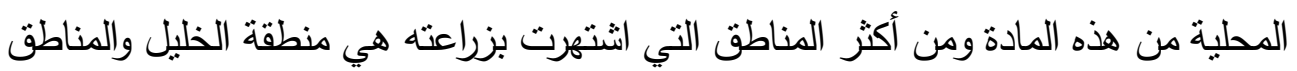

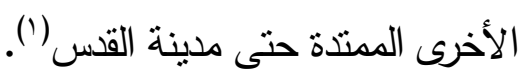

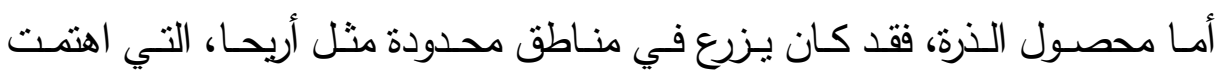

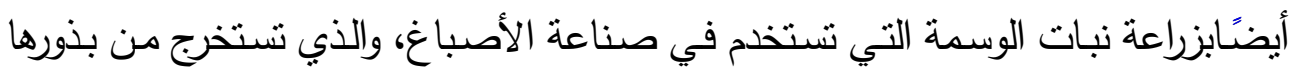

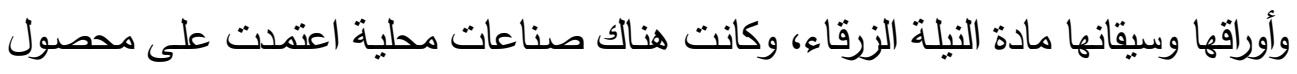

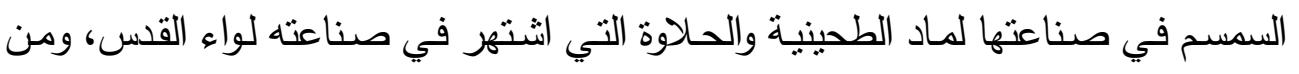
المناطق التي اثتهرت واهتم بزراعة محصول السمسم هي: صور باهر ، وبيت لحم، وبيت نوبا، ويالو (r).

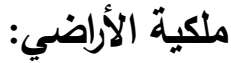

أولى العثمانيون اهتمامًا كبيرًا أنتاء توسعاتهم العسكرية إلى الأراضي التي بسيطرون

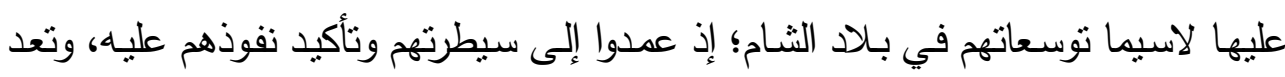

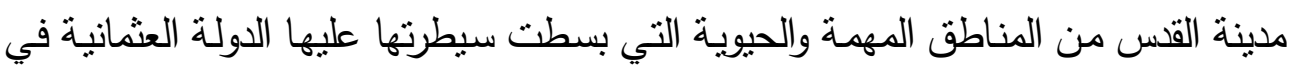

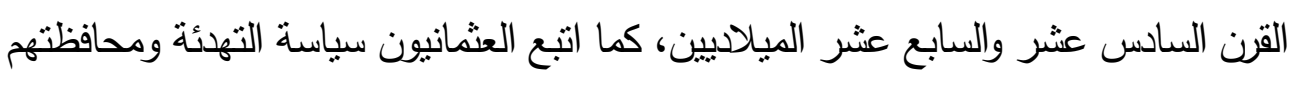

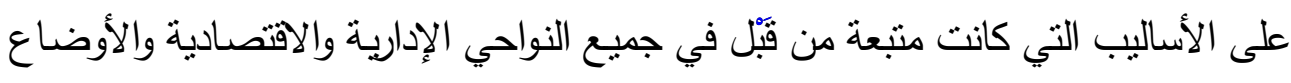

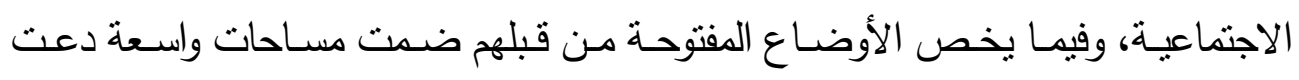

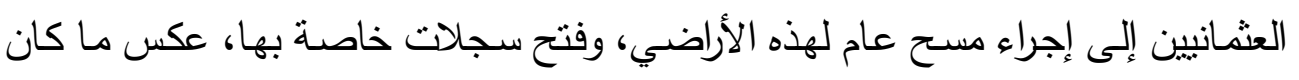

( (1) مجموعة من المفكرين العرب: دراسـات في التتمية وإلتكامل الاقتصادي العربي، طץ، مركز دراسـات

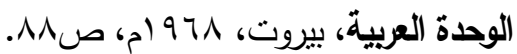

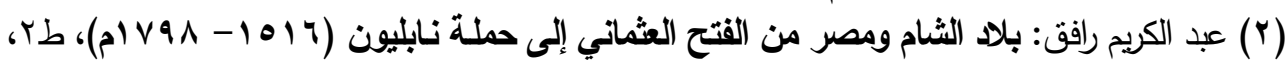
(د.ن)، دمشق، 


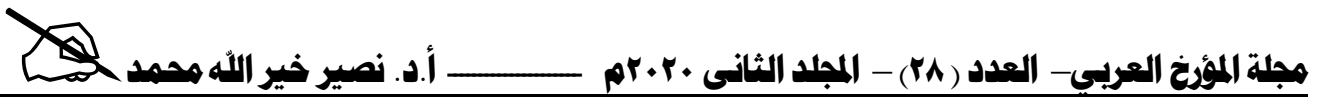

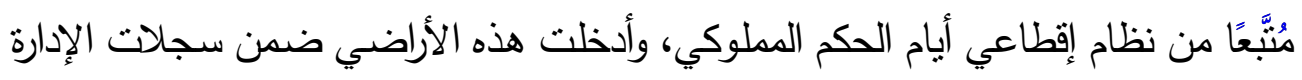

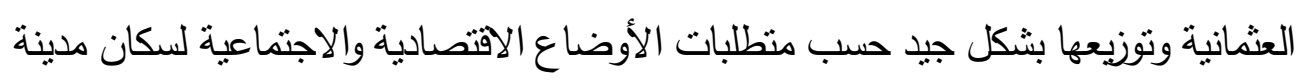

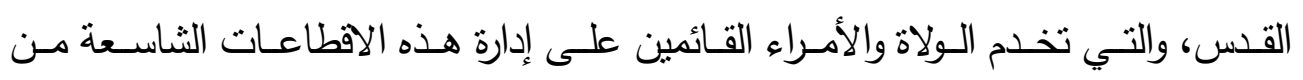
الأراضي (').

\section{ومن هذه التقسيمات لأراضي القسس هي:}

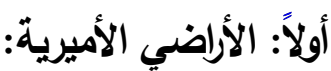

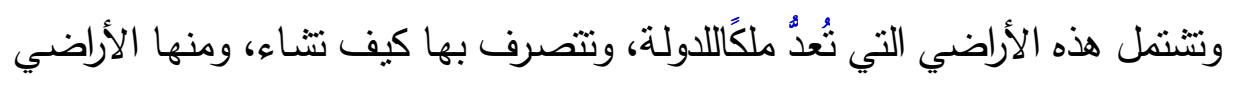

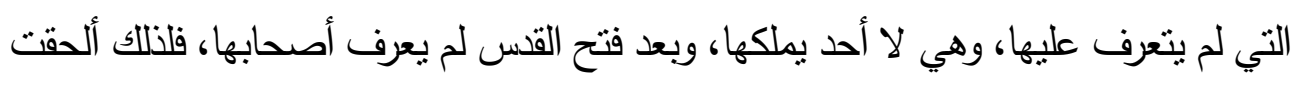

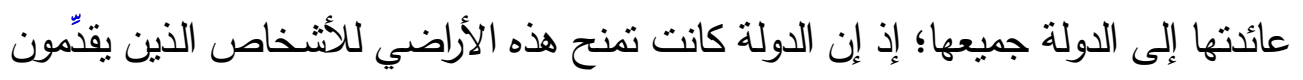

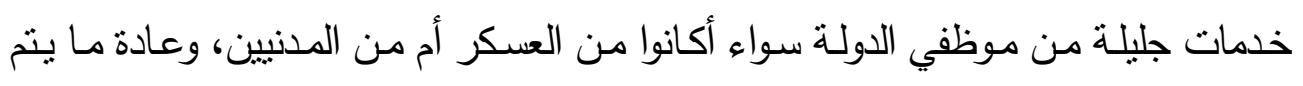

توزيعها على شكل إقطاعات منتظمة (r).

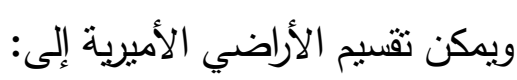

أ - أراضي الخاص السلطاني:

وهي التي تكون في تصرف السلطان، وعادة ما تكون هذه الأراضي هي التي غنمها

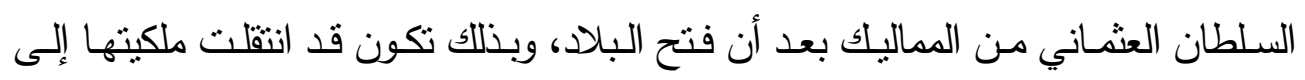

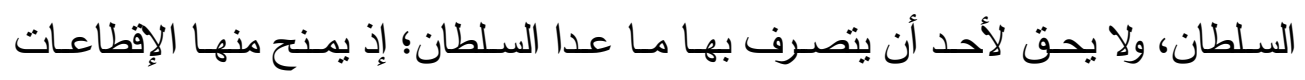

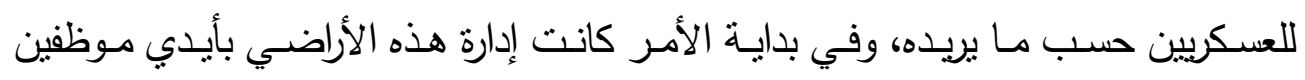

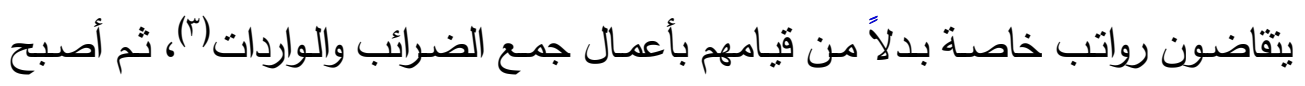

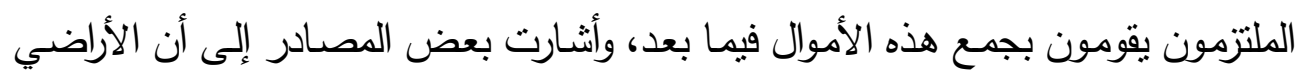

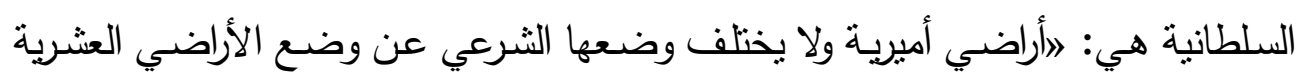

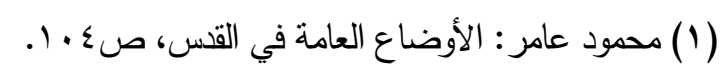

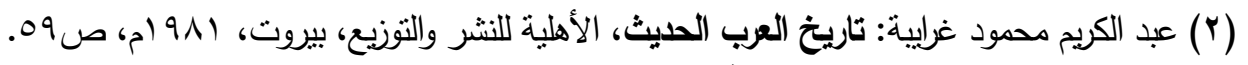

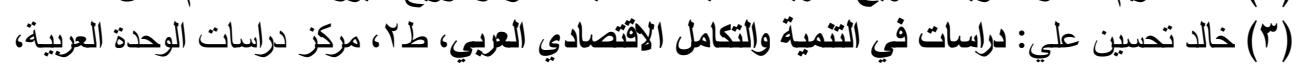

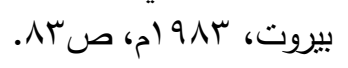




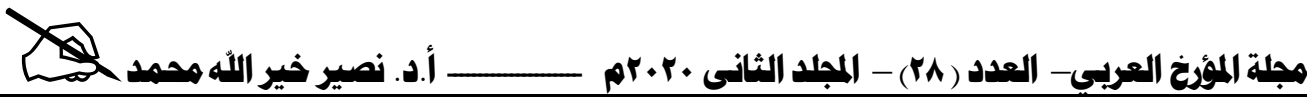

الخاصة؛ وذللك لأنها أراضٍ تعود رقبتها أي عائدتها إلى الدولة، بينما يتمتع أصحابها بحقوق

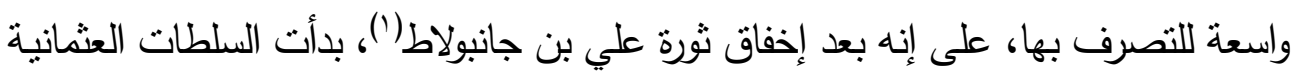

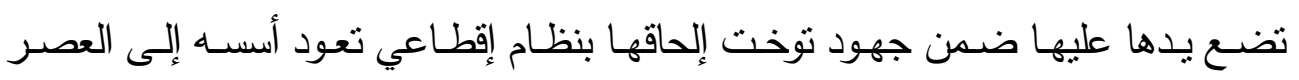

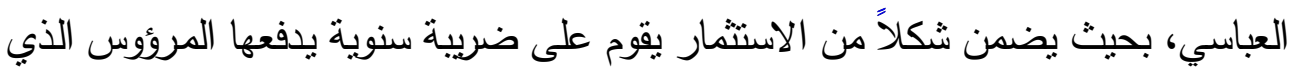

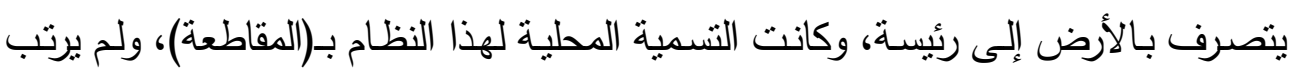
عليها التزامات عسكرية، ولكنها كانت قائمة على دفع الخراجه (؟).

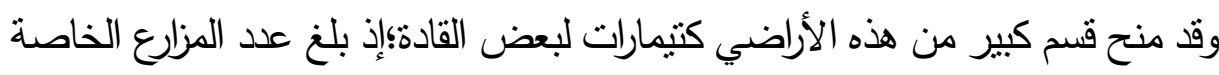

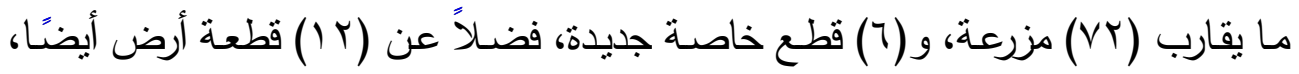

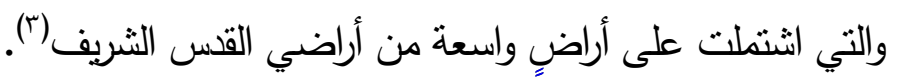
ب - الإقطاعات العكرية:

تُعدُّ هذه من الأراضي التي أدخلت في النظام الجديد للأراضي، الذي أعدته الإدارة

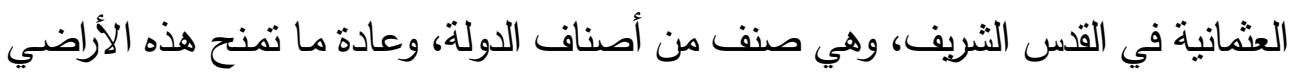
للعسكر مقابل ما يبذلونه من جهود في الحروب، وقد احتفظ السلاطين العثمانيون بأجودها لأنفسهم، وتضم مساحات كبيرة مميزة، وكنلك تم اقتطاع أراضٍ واسعة لتوزيعها على الوزراء

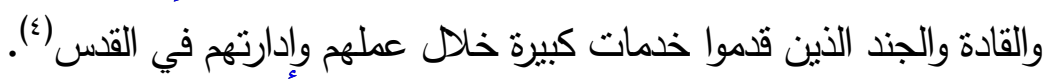

(1) هو علي بن أحمد بن جانبولاط بن قاسم الكردي القصيري، وجده جانبولاط الششهور بابن عربوا أمبر لواء

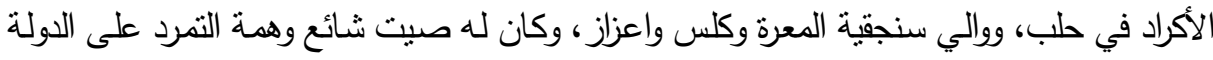

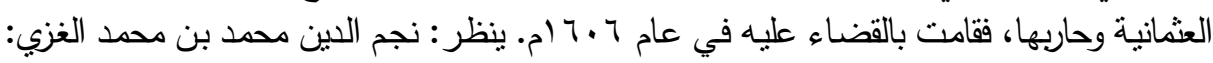

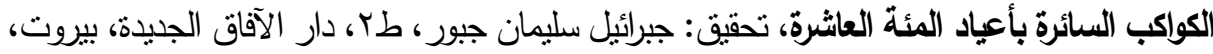
(

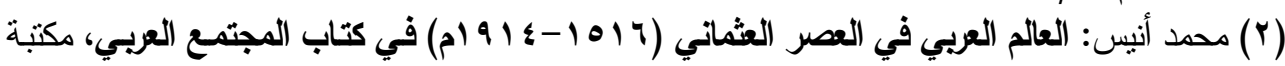

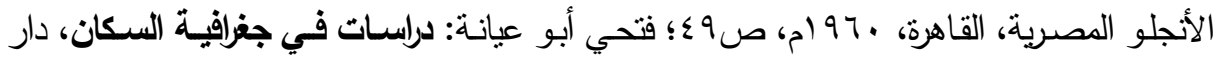

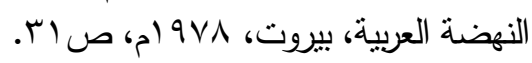

(ץ) عماد الجواهري: الأوضـاع الاقتصـادية في فلسطين في العصر الحسيث، مطبعة النهضة، بغداد، (4)

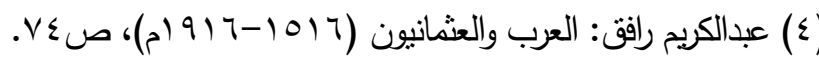




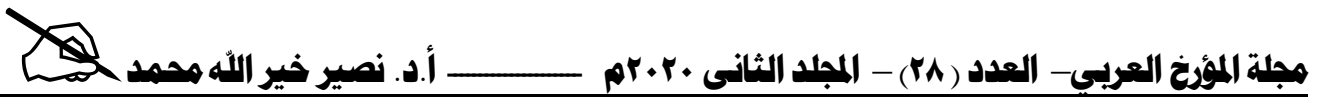

\section{وتصنف أرضاضي الإقطاعات العكرية إلىى: \\ 1 - خاص أمير اللواء:}

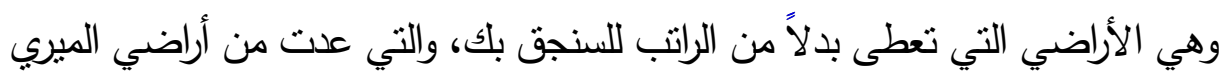

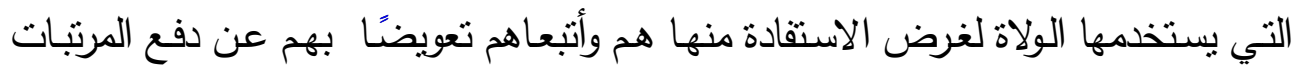

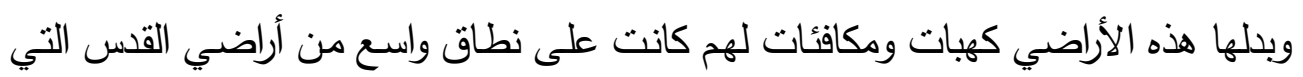

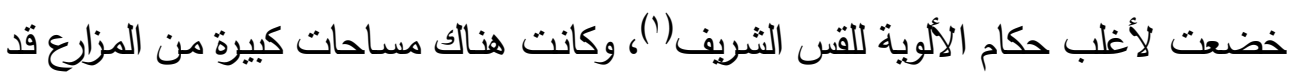

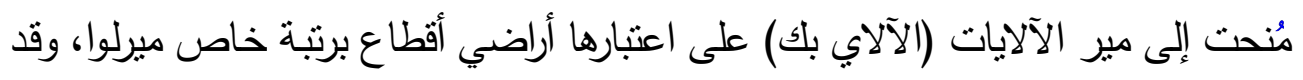

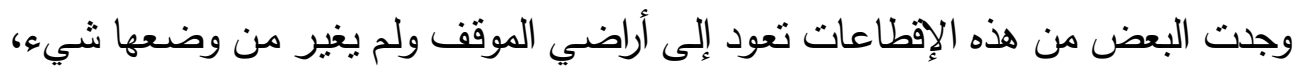

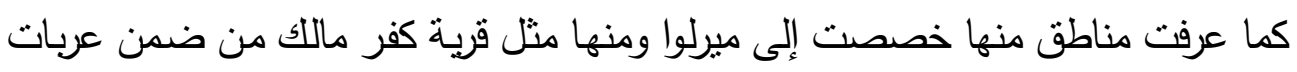

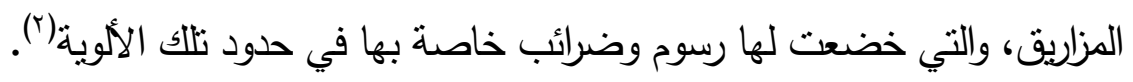

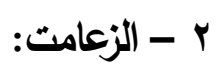

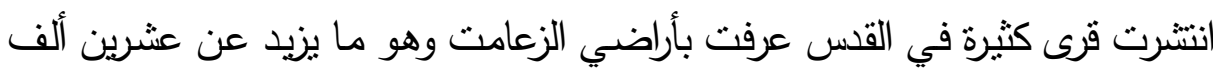
أقجة، وعادة ما تمنح هذه الأراضي لكبار الموظفين وضباط الجيش من القادة والأعيان مثل

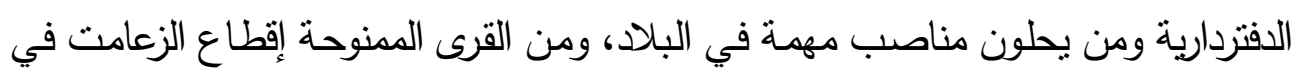

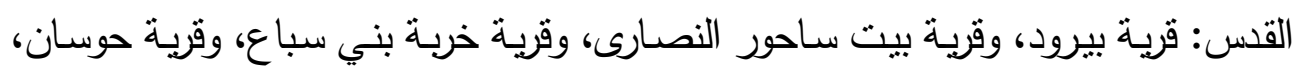

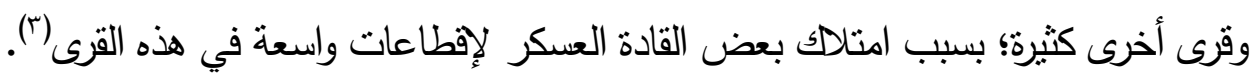

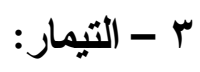

شمل هذا النوع من الإقطاع قرى كبيرة في القد، ويُعدُّ من أكثر الإقطاعات انتشارًا

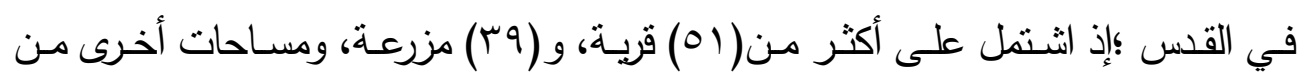

( (1) الصفصافي أحمد الموسى: الدولة العثمانية والولايات العربية، مجلة الدارة، العدد())، السنة الثانية،

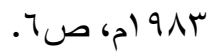

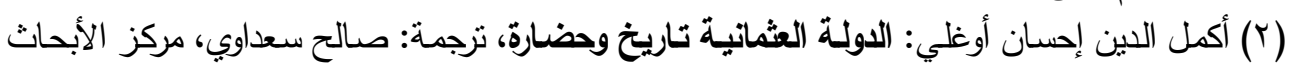

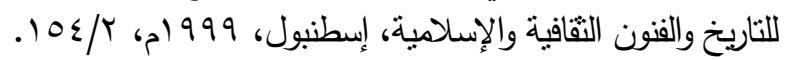

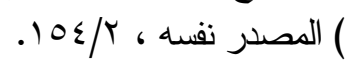




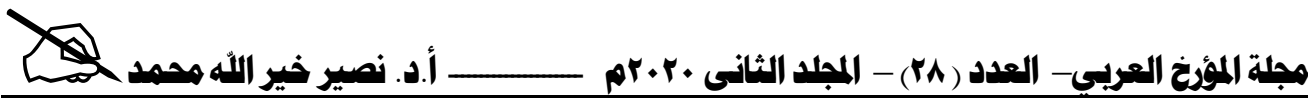

الأراضـي التابعة للقس، وكانت هناك تيمارات بنوعين وهي تنمار بتذكرة، وتميار بدون

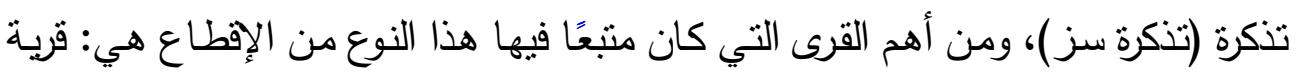

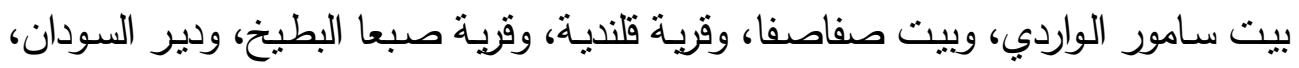

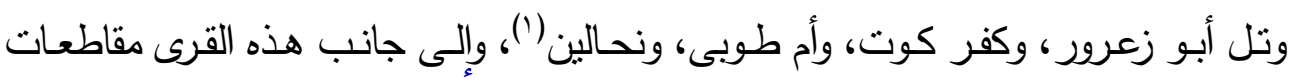

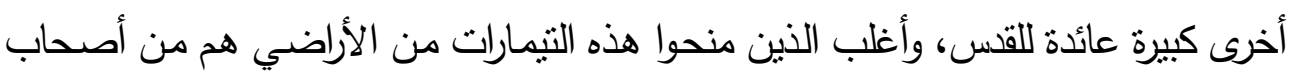

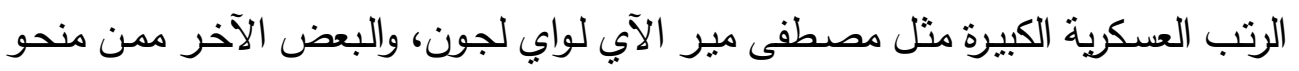

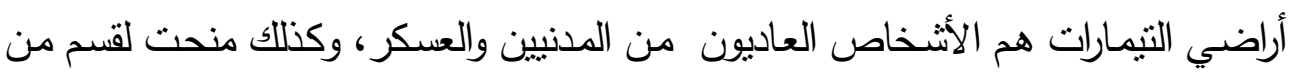

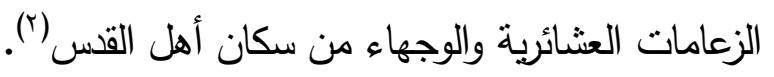

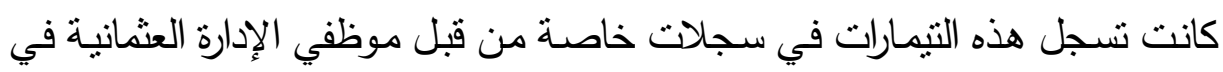

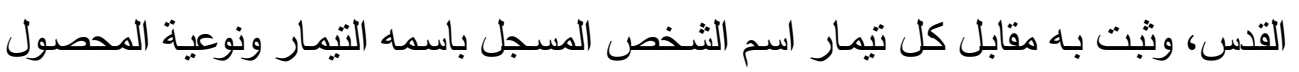

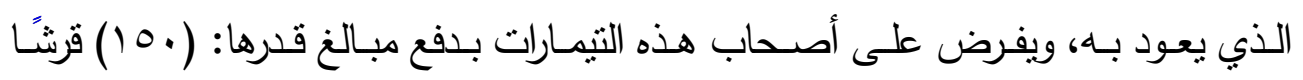

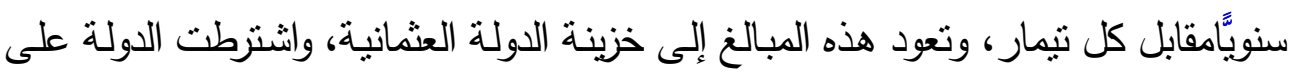

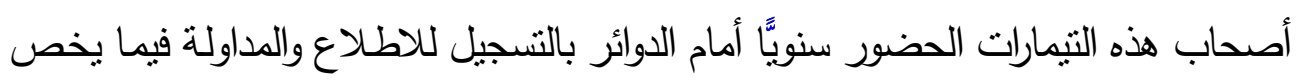

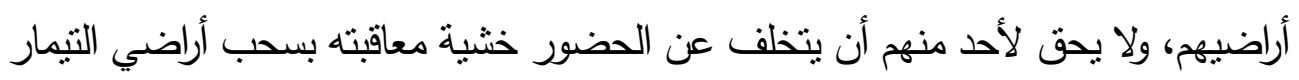

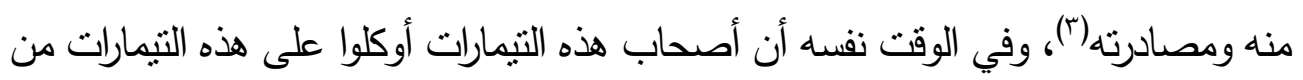

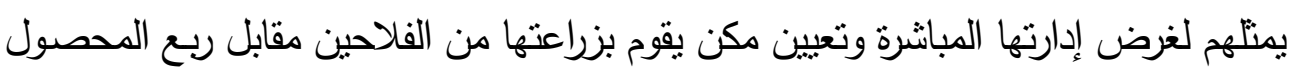

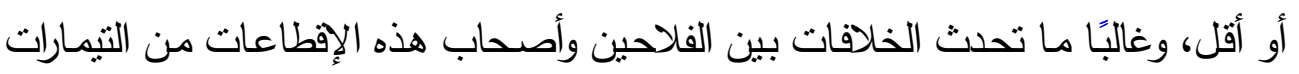
بسبب تقاسم الحصص فيما بينهم (\&).

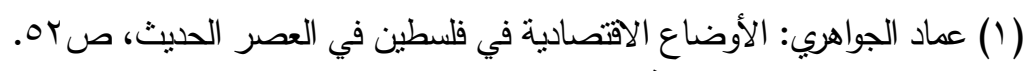

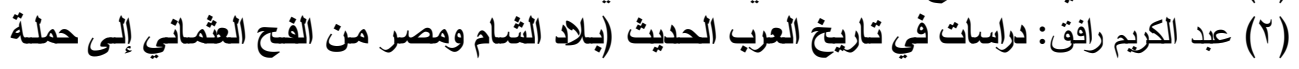

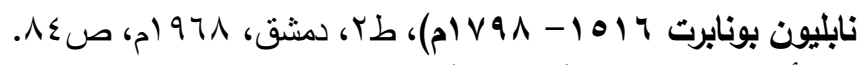

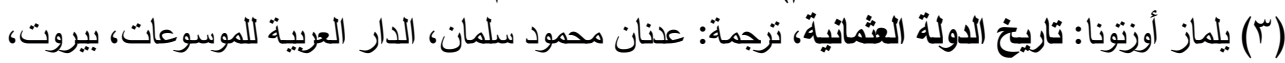

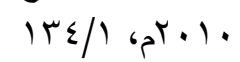

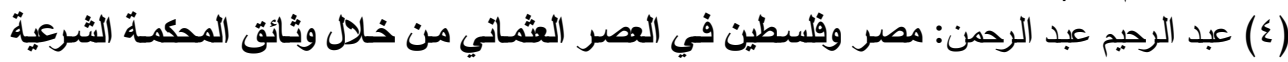

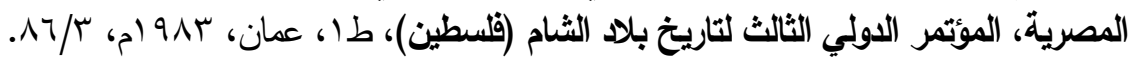




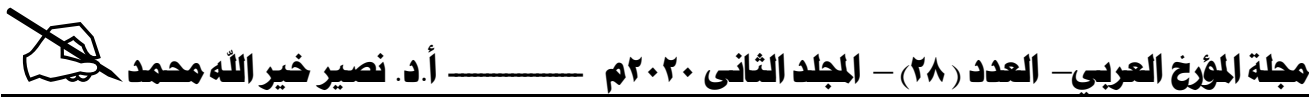

ومن ناحية أخرى حاول بعض المالكى لهذه التيمارات من المتتفذين بالسلطة من تحويل

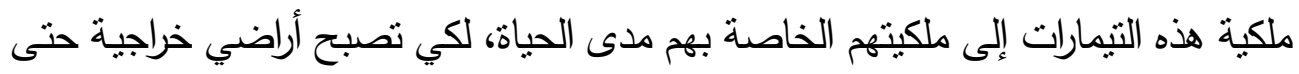

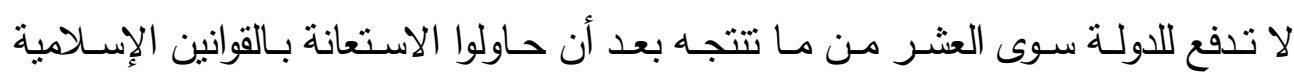

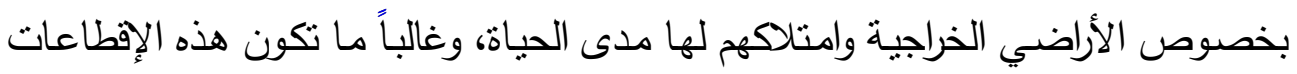

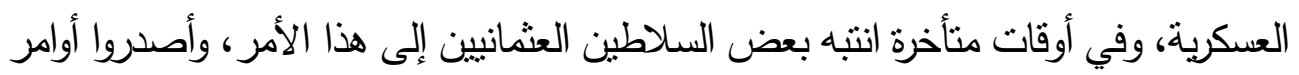

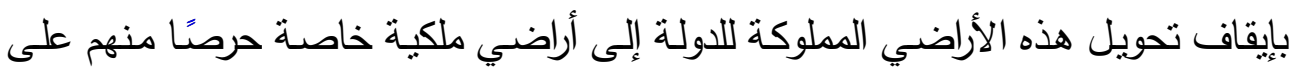

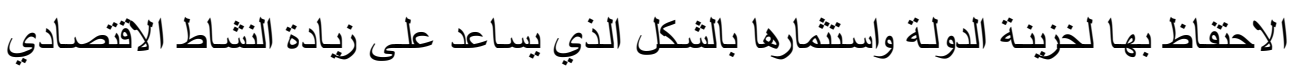

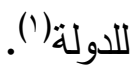

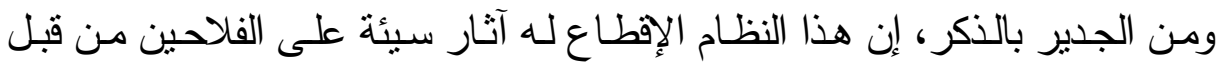

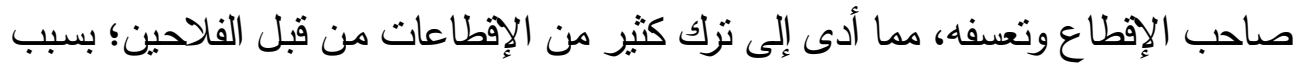

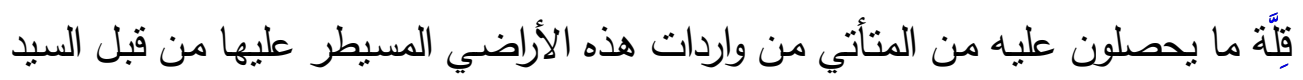

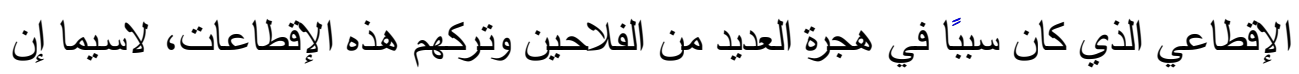

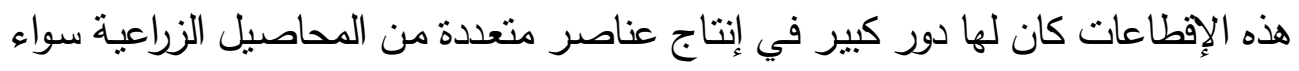

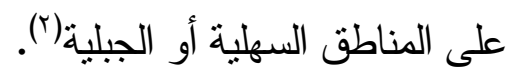

$$
\text { ج - الأراضي المشاعة: }
$$

تعود ملكية هذه الأراضي إلى بيت المال، وتسمى الأراضي الأميرية وعادة ما تكون

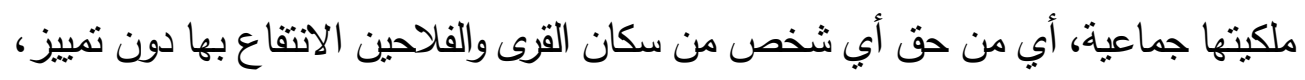

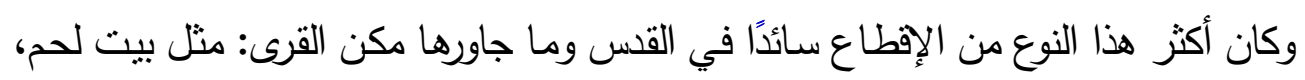

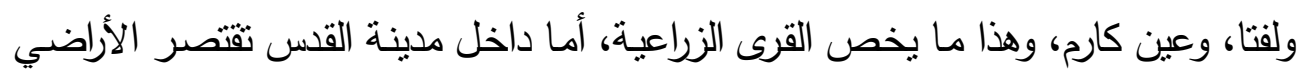
المشاعة على الذي يسكنها المواطنون من أهل المدينة(r).

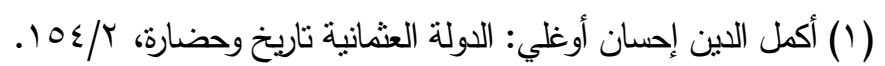

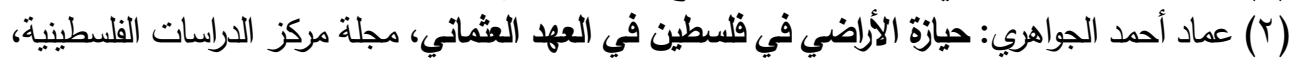

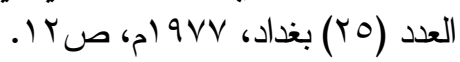

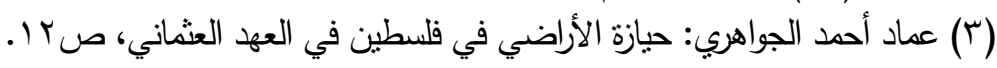




$$
\text { د - الأراضي المتروكة: }
$$

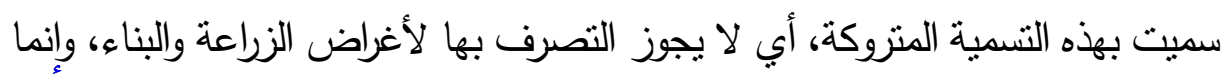

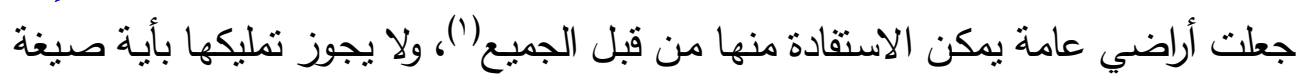
من صيخ الملكية سواء أكانت ملكية خاصة أم غيرها، ونقسم هذه الأراضي إلى فلى قسمين:

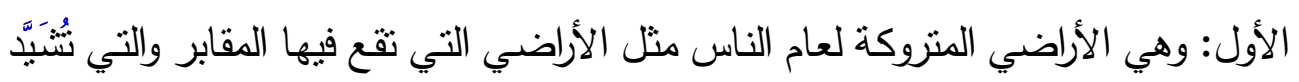

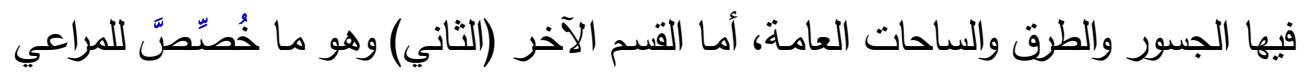

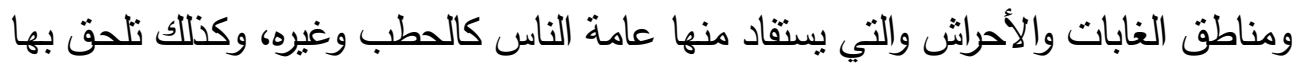

$$
\text { أراضي الأسواق العامة وغيرها(†). }
$$

عادة ما تكون هذه الأراضي قليلة ومحدودة في القدس؛ إذ تشتنل على أراضي خالية

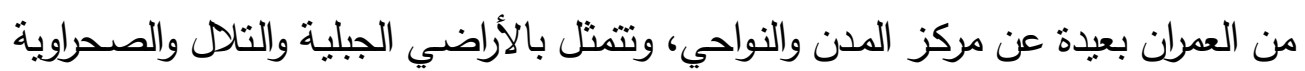

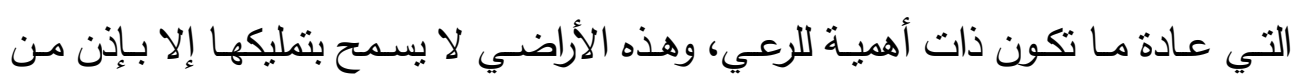

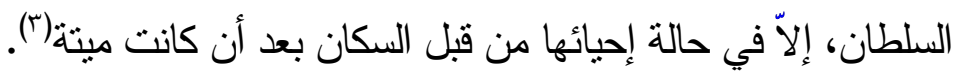

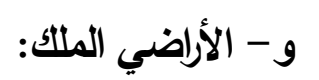

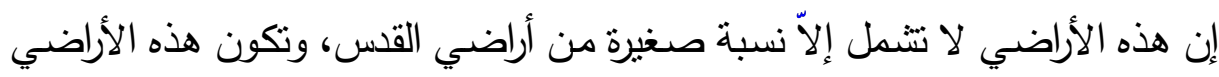

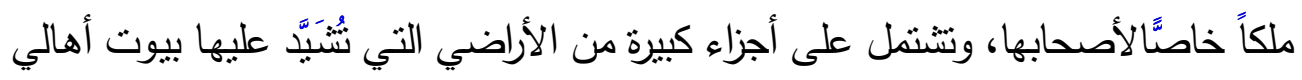

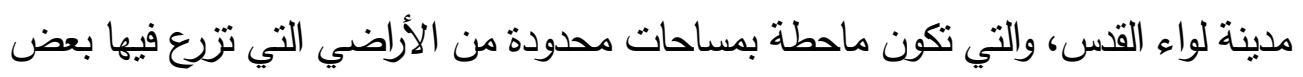

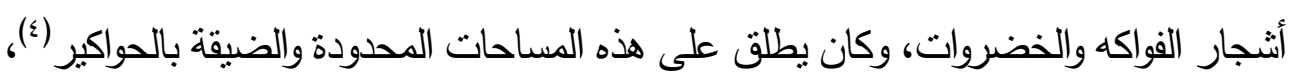

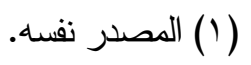

(Y) محمد سليمان: قانون التظظيمات العثماني وتملك اليهود في أرض فلسطين، مجلة صامد الاقتصادية،

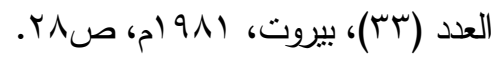

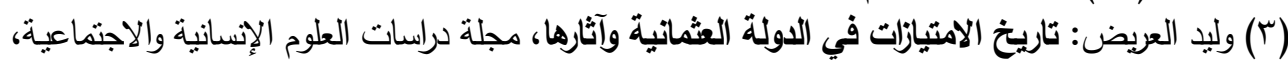

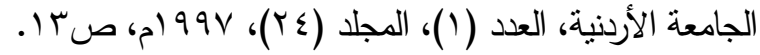

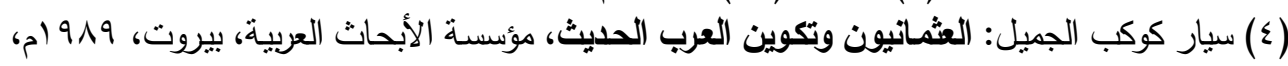




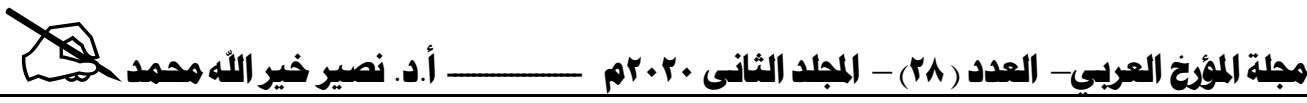

فضلاً عن وجود أملاك للأهالي من المقسيين قريبة من الحرم القدسي كالمحلات والدكاكين

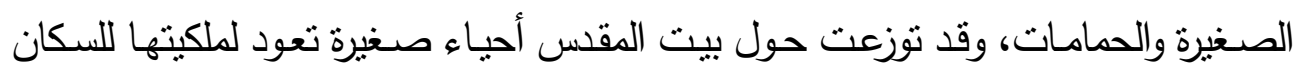

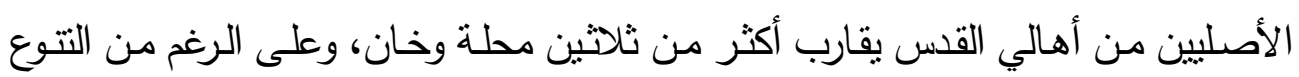
السكاني في هذه المناطق إلاّ إن الغالبية العظمى منها للمسلمين (').

$$
\text { ز - أراضي الملكيات القربية: - مائ }
$$

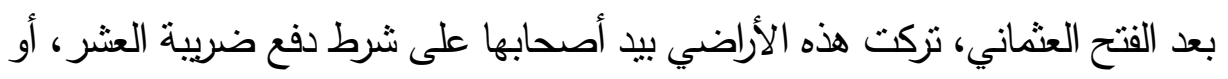

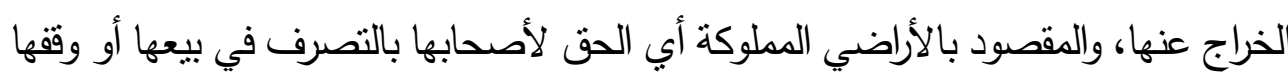

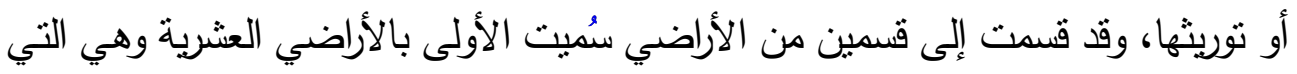

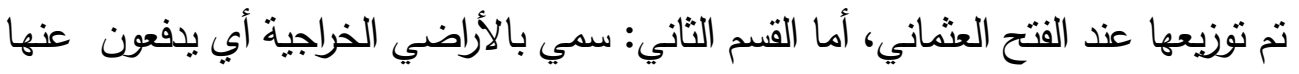

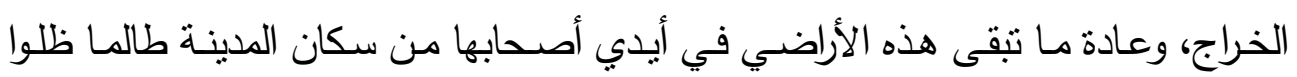
محافظين عليها لغرض زراعتها والاستفادة منها (†).

\section{ح- أراضي الوقف:}

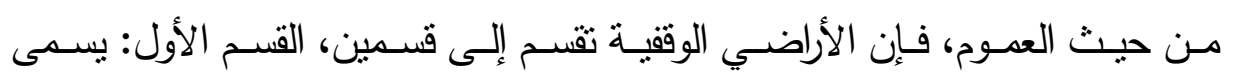

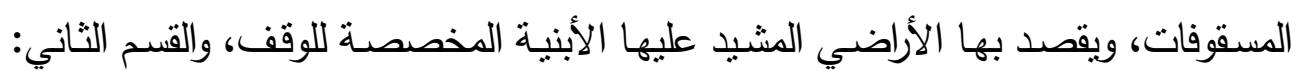

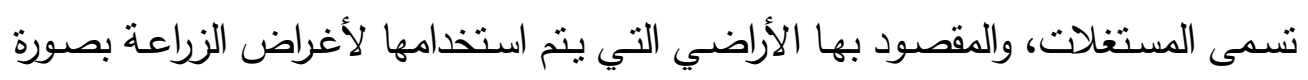

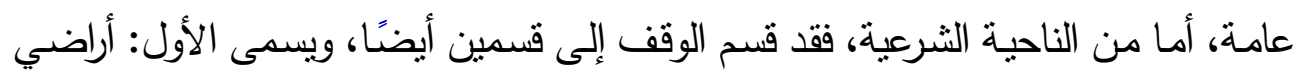

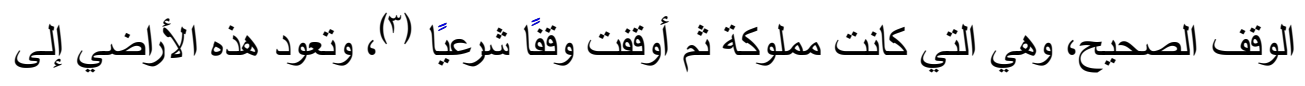

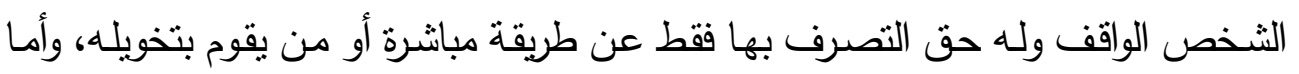

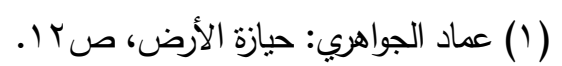

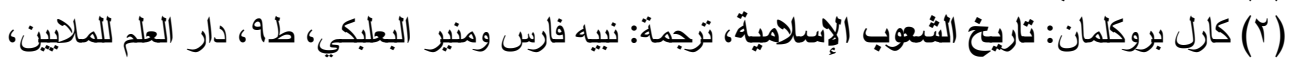

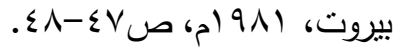

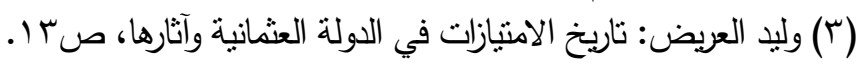




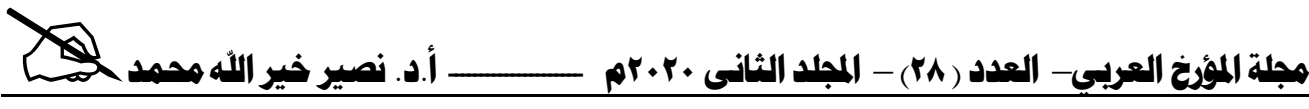

الثاني: فيسمى أراضي الوقف غير الصحيح، وهو ما أوققه السلطان للأعمال الخيرية من الأن الأني

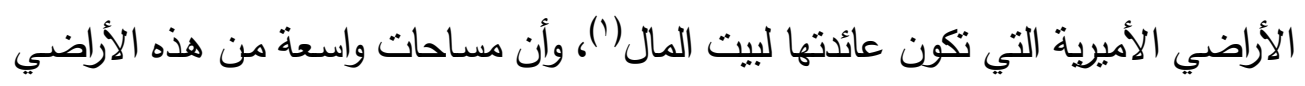

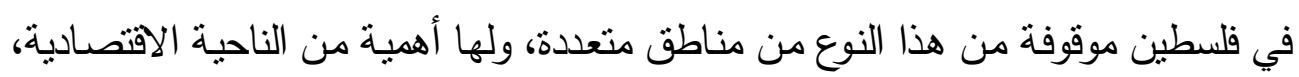

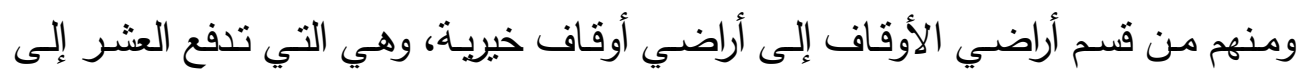

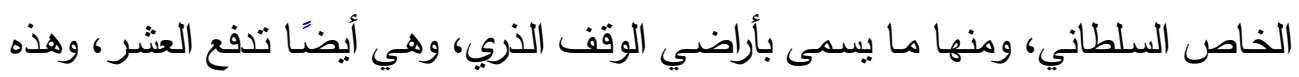

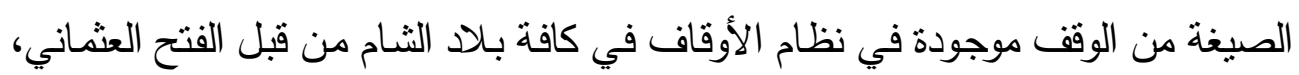
سوى الأراضي المحبسة والموقوفة على الحرمين الثريفين، فإنها تعفى من ضريبة العسر (؟).

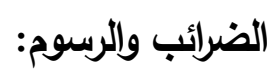

اهتم العثمانيون بموضوع الضرائب وطرق جبايتها في المناطق التي خضعت لسيطرتهم،

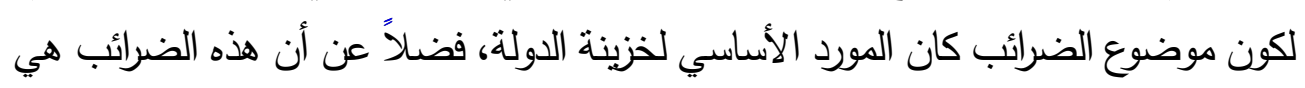

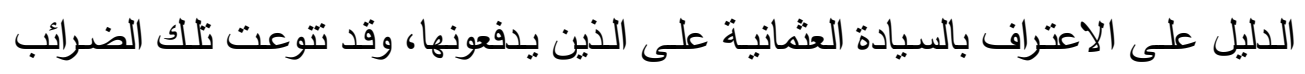

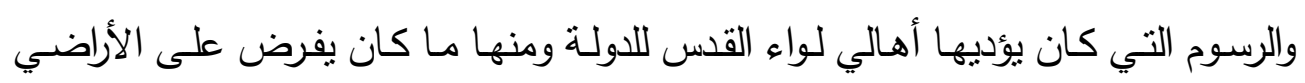

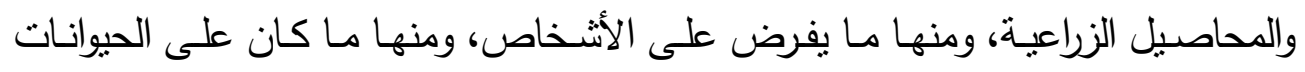

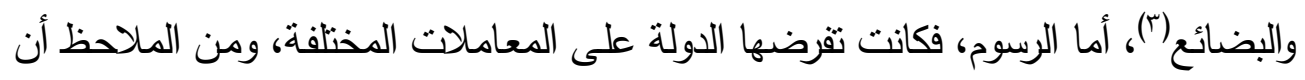

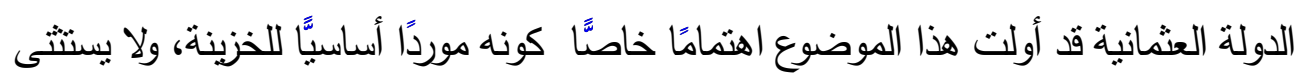

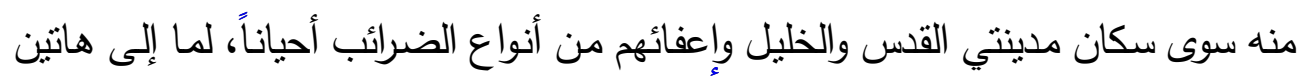
المدينتين من قدسية عند المسلمين عامة (؛).

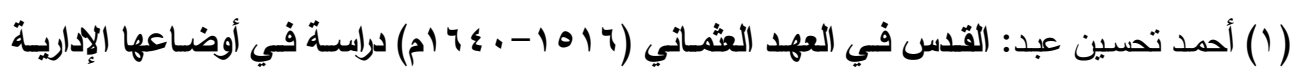

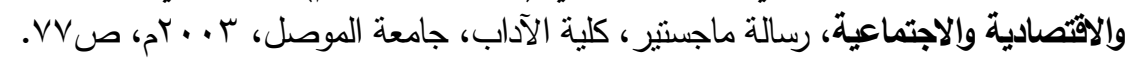

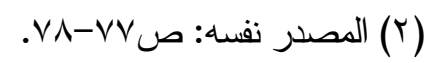

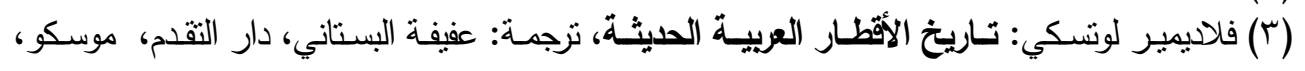

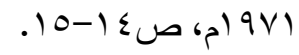
(§) روبير مانتزان: تاريخ الدولة العثمانية، ترجمة: بشير السباعي، طا، الدار الوطنية، القاهرة، بو9 (م، 


\section{ويمكن تقسم هذه الضرائب والرسوم إلىى عدة أنواع:}

$$
1 \text { - الضرائب المفروضة على الأراضي: }
$$

تقسم الضرائب المفروضة على الأرض إلى قنمين، الأول: الخراج، ويقصد به الضريبة

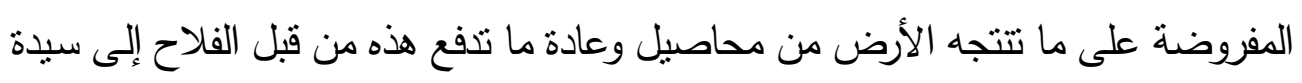

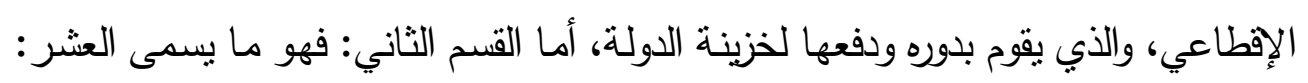

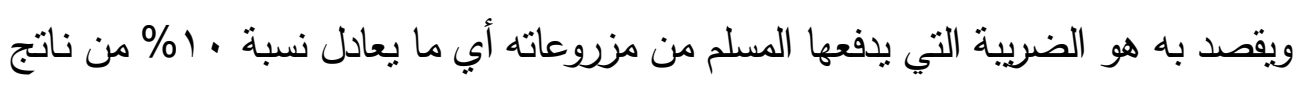

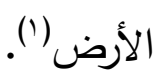

\section{r - الضرائب المفروضة على المحاصيل الزراعية:}

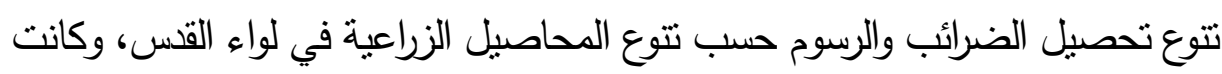

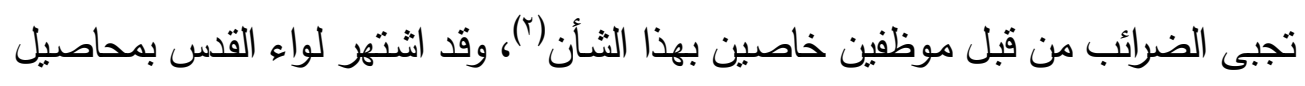

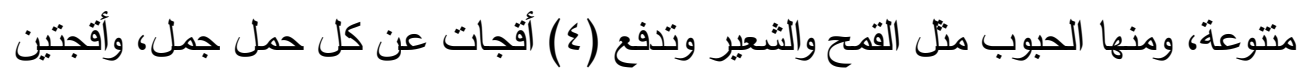

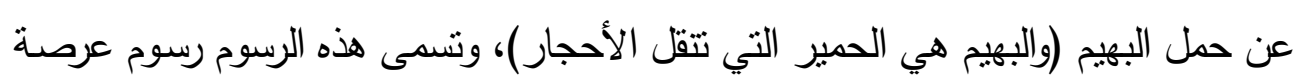

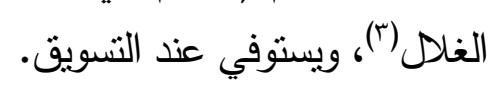

أمسا ضريبة الزينون، تكون على شكل نظامين في استحصسال الجباية حسب نوعية

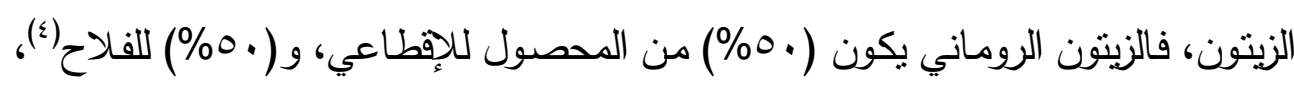

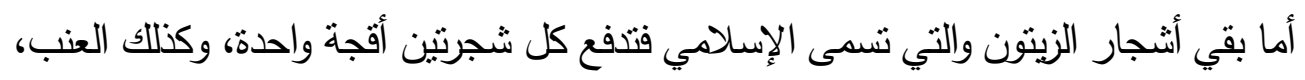

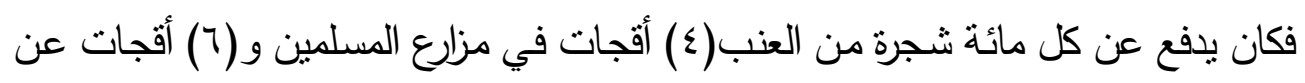

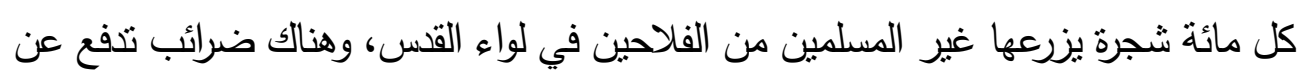

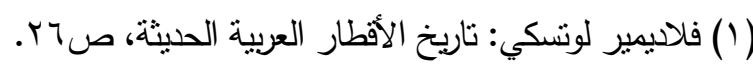

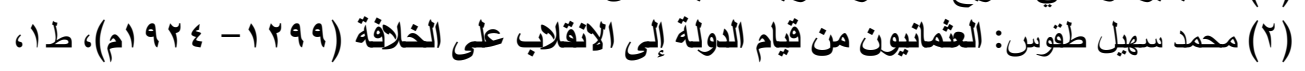

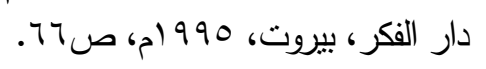

(ץ) عرصة الغلال: ساحة الغلال. مجمع اللغة العربية: المعجم الوجيز، طبعة منقحة، مكنبة الثروق الدولية،

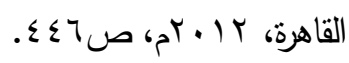

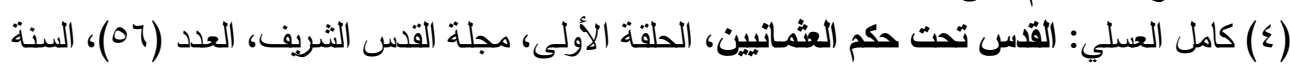

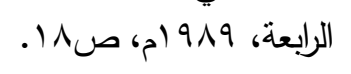




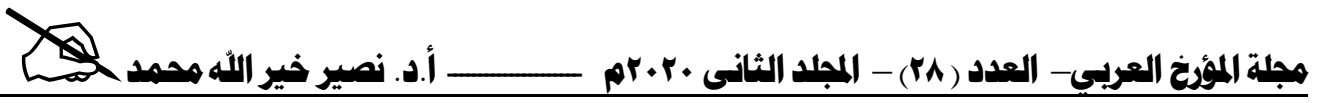

أثنجار النوت والتين لكل أربع أنثجار أقجة واحدة، أما الضرائب عن أثنجار الجوز الهثر

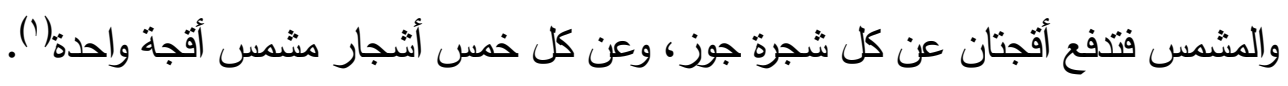
r - الضرائب المفروضة على الفلاحين:

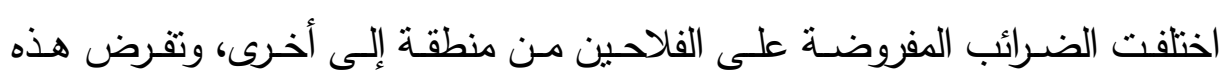

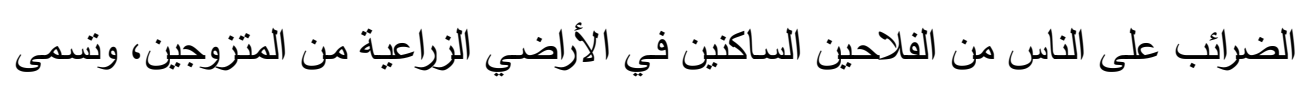

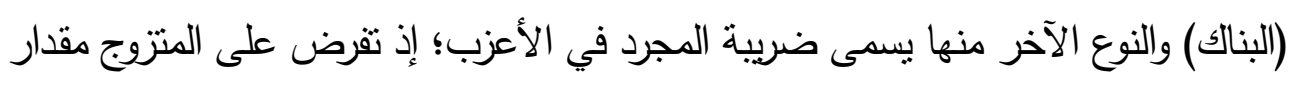

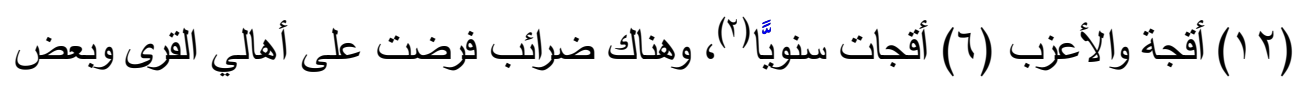

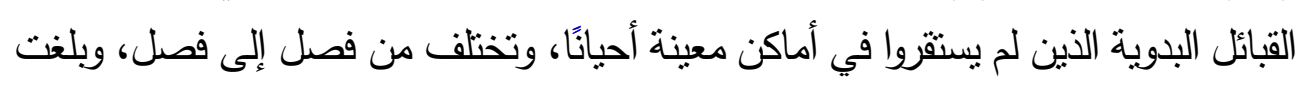

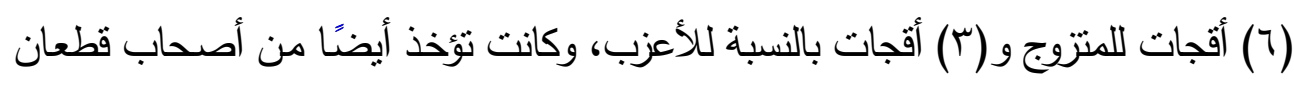

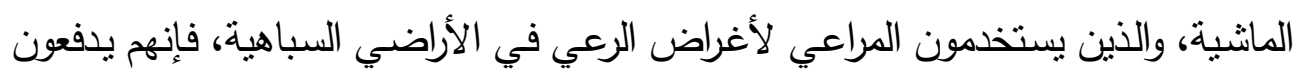

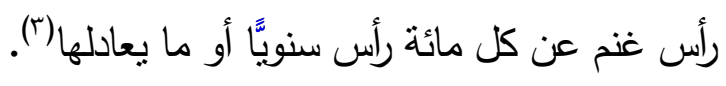

$$
\begin{aligned}
& \text { ؛ - الضرائب المفروضة على الحيوانات: }
\end{aligned}
$$

كانت الضرائب التي تقرض على المغرضة على الحيوانات التيات التي يستخدمونها للركوب والنقل منل الجمال

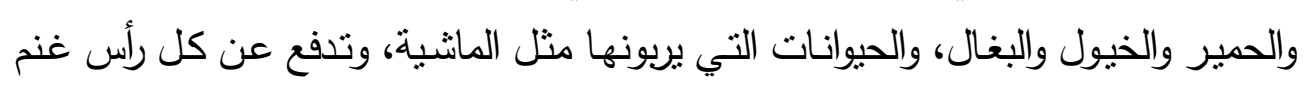

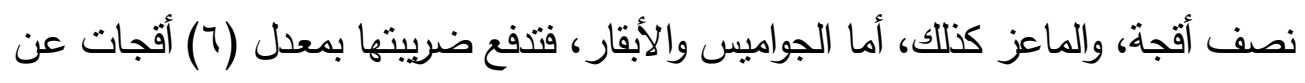

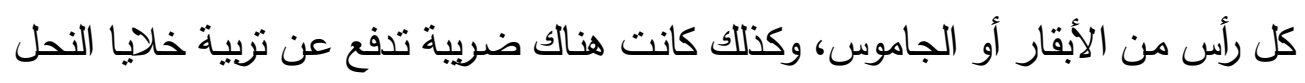

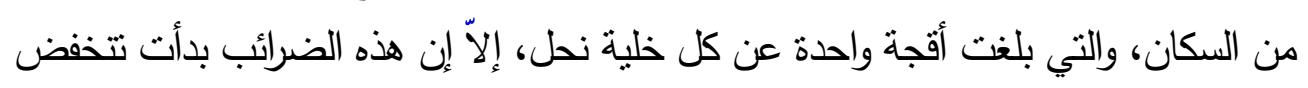

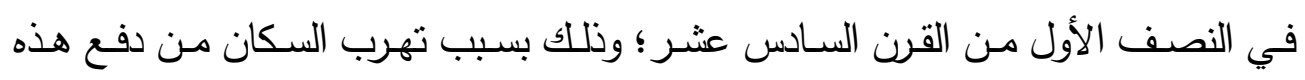

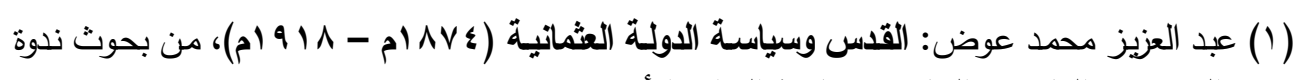

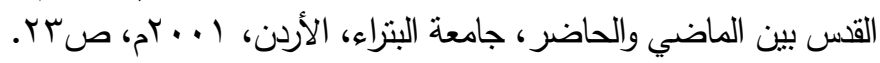

(Y) إبراهيم رضوان الجندي: التجارة والرسوم الكمركية في فلسطين، مجلة آفاق عربية، العدد(؟)، السنة

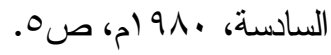

(ץ) محد حسين محاسنة وآخرون: تاريخ مدينة القس في العهل العثاني، مكتبة الفلاح، بيروت، ؟ . بام،

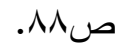




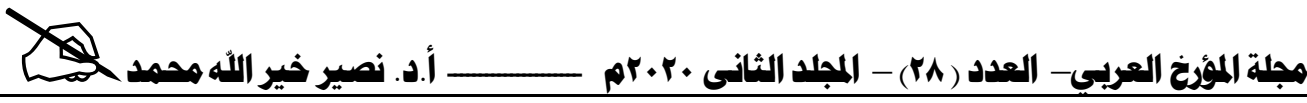

الضرائب؛ وسبب هذا التهرب من ففع الضـرائب هو النتاقص الذي حصل في قطعان

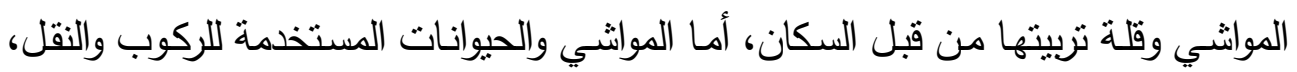

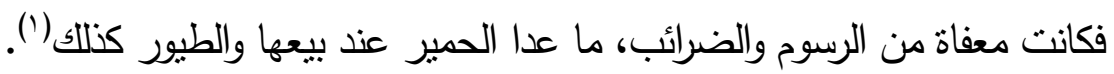

$$
\text { 0 - الضرائب المفروضة على المنشآت في الأراضي الزراعي: }
$$

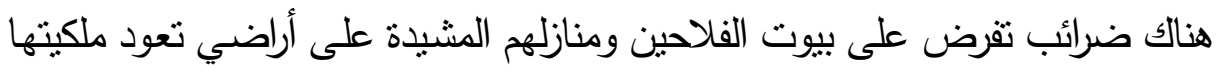

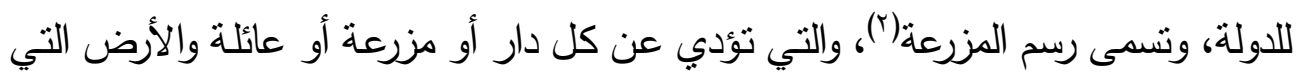

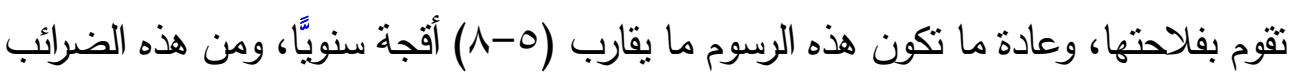

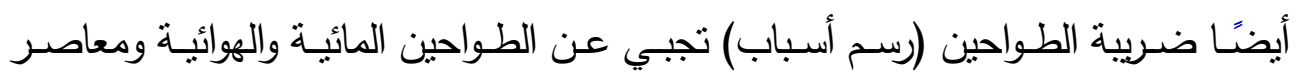

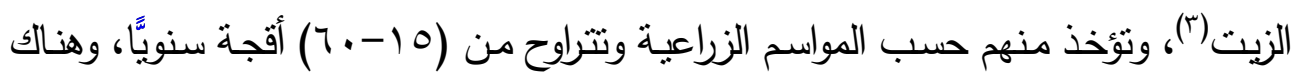

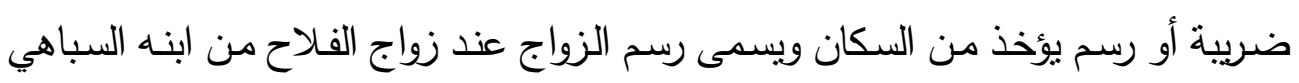

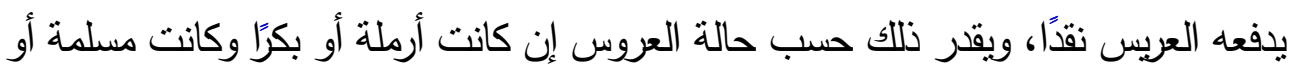
غبر مسلمة أو جارية أو حرة، وذلك يقدر حسب الحالة الواقعة (ئ.

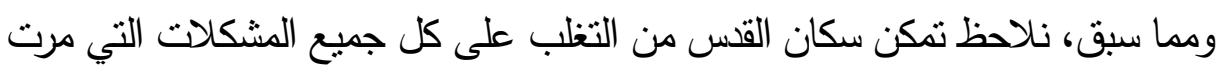

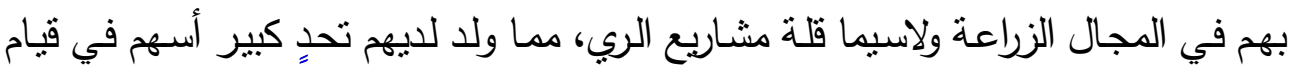

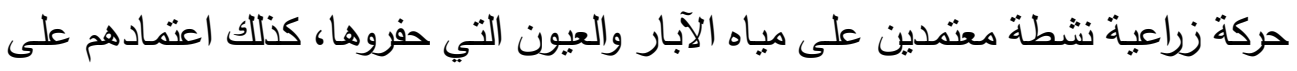

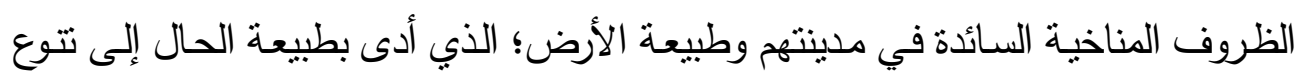
المحاصيل الزراعية في المدينة.

( (1) شكيب أرسلان: ت تاريخ الدولـة العثمانيـة، نحقيق: حسن السماحي سويدان، دار ابن كثير، بيروت،

$$
\text { (1) }
$$

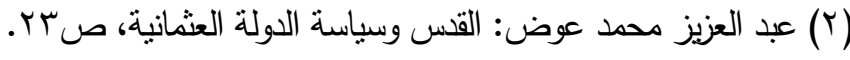

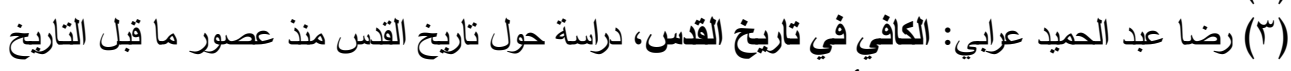

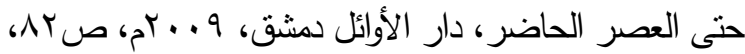
( ) جاسر علي العناني: القس لراسات قانونية وتاريخية، منثورات أمانة عمان الكبرى، الأردن، ... بام،

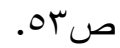




\section{المبحث الثاني: الصناعة}

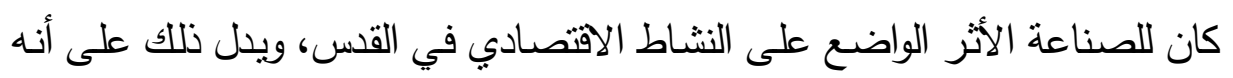

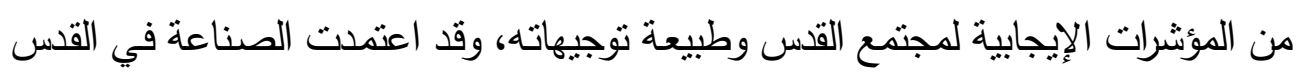

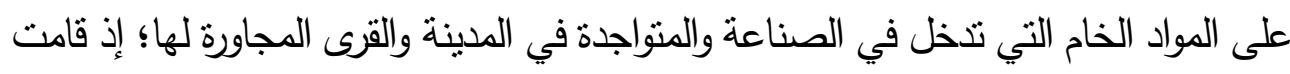

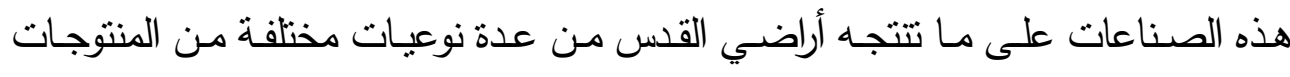

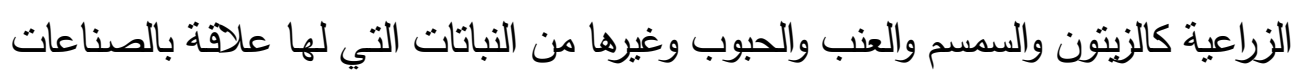

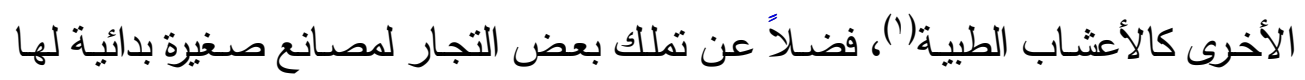

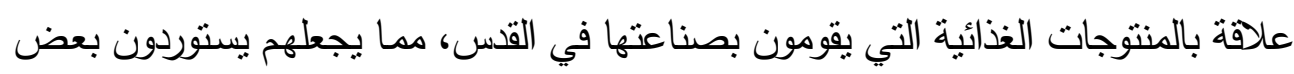

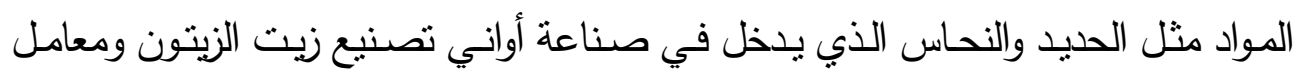

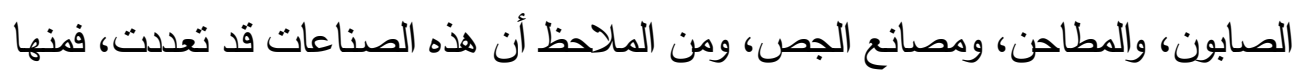

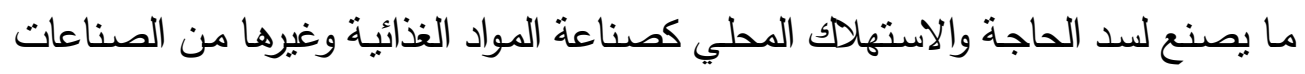

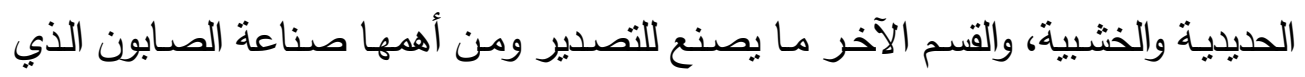

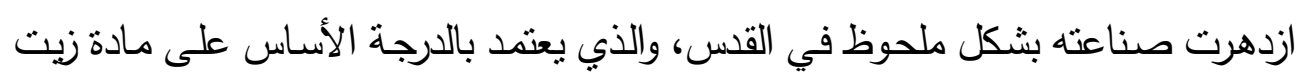

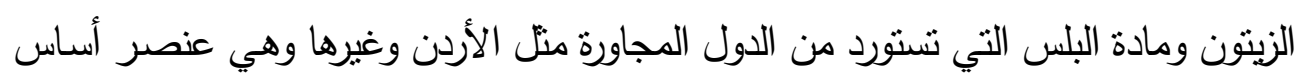

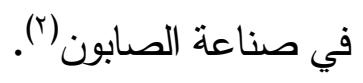
وقد ساعد انتتار ووفرة الثروة الحيوانية في المدينة على ازدهار صناعة الألبسة لوفرة

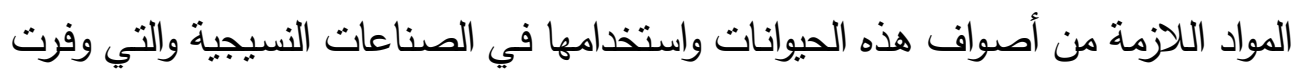

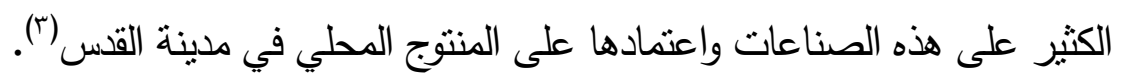

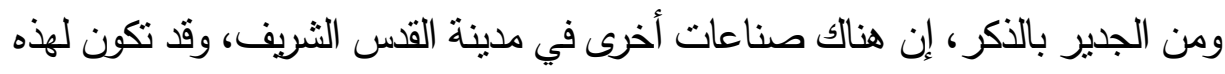

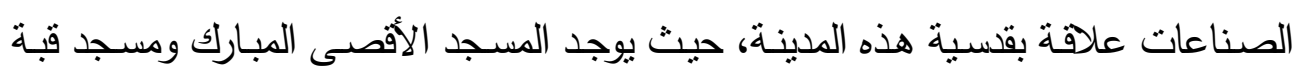

( (1) فاضل بيات: دراسات في تاريخ العرب في العهل العثماني روئة جليدة في ضوء الثوثائق العثمانية، دار

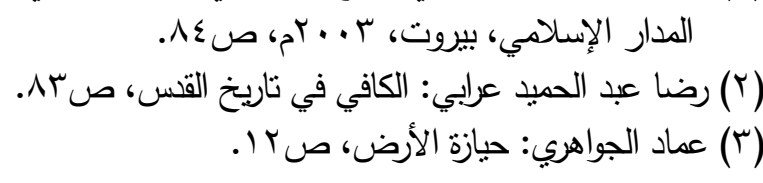




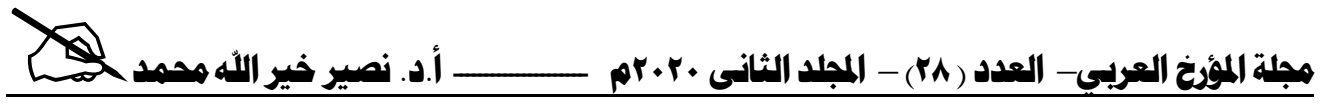

الصخرة وكنسية القيامة، التي ساهمت في ظهور صناعات محلية تتلاهم مع أذواق الحجاج

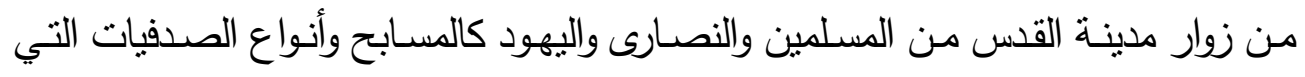

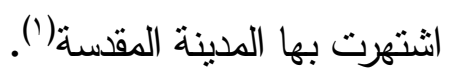

\section{ومن أهم هذه الصناعات هي:}

\section{أولاً: صناعة الأغذية:}

أ - صناعة زيت الزيتون والصابون وإلتحف والصدفيات:

تعتمد هذه الصناعة بالدرجة الأولى على شجرة الزيتون التي انتشرت زراعتها والتها في مدينة

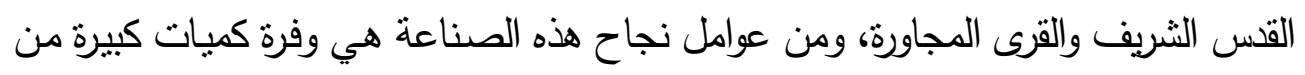

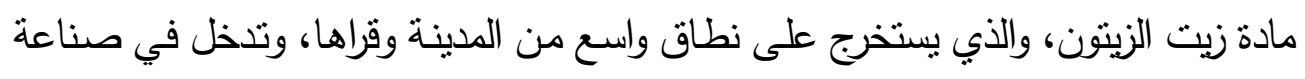

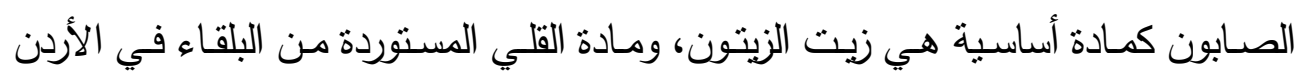

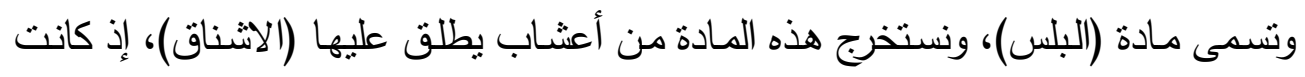

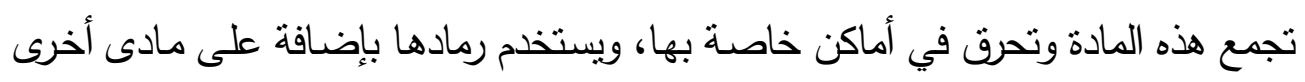

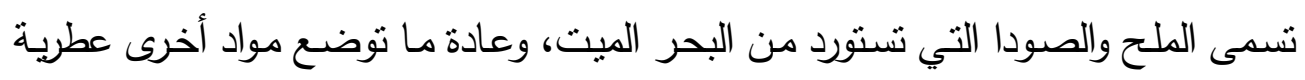

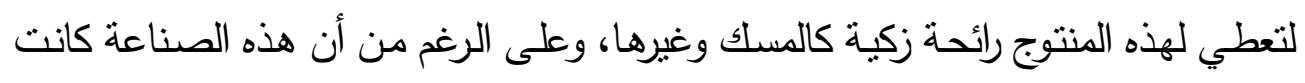

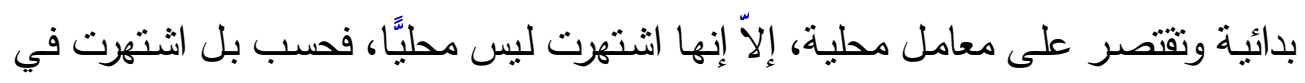

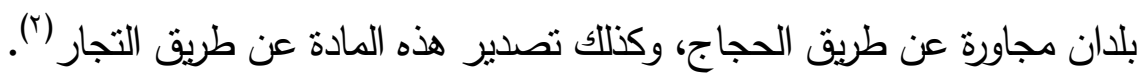

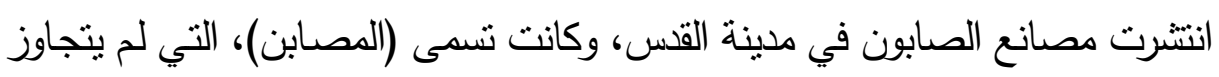

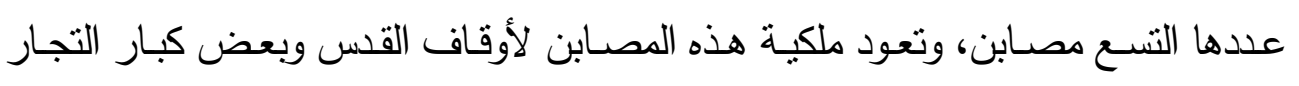

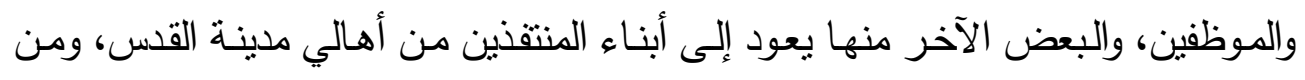

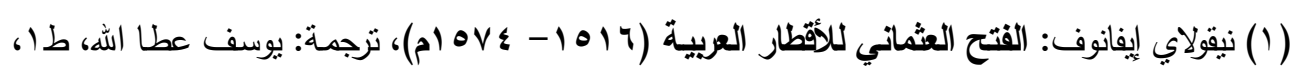

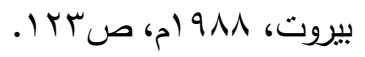

(Y) أحمد محمد الربايعة: الصناعات في فلسطين في العصور الصيثة، المؤتمر الدولي لتاريخ بلاد الثنام-

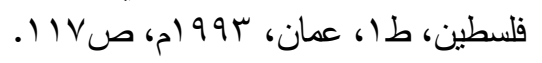




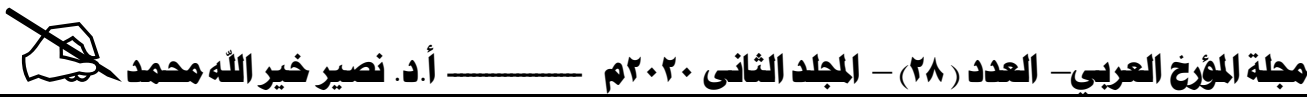

العائلات المعروفة التي تمنلك هذه المصانع منل مصبغة محمد أمين الدقاق في سوق الزيت

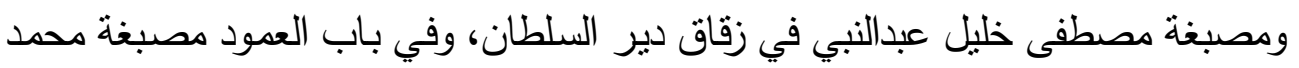

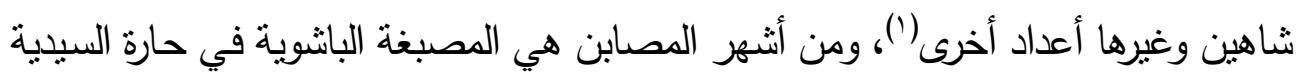

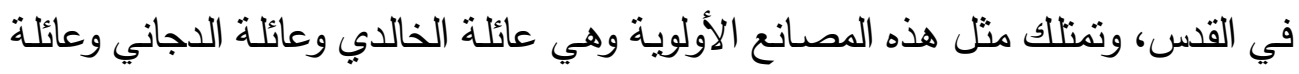

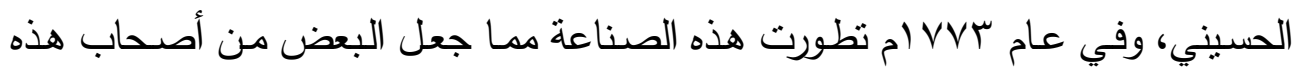

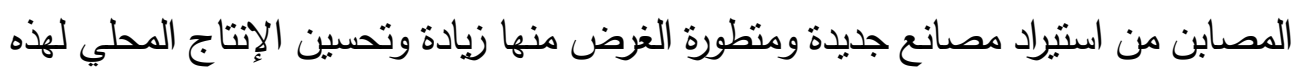

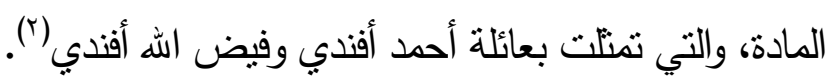

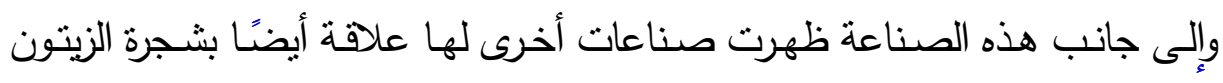

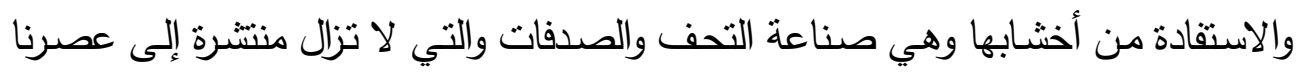

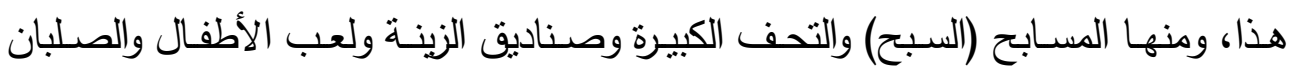

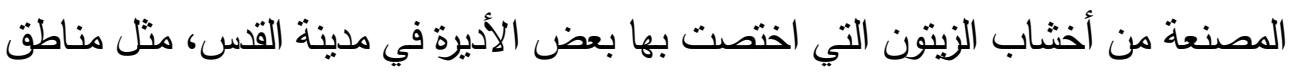

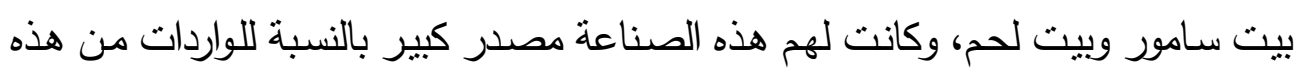

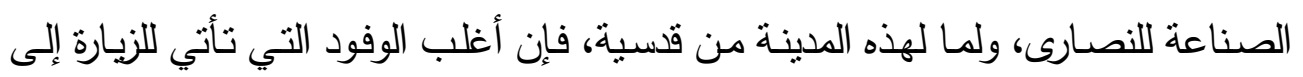

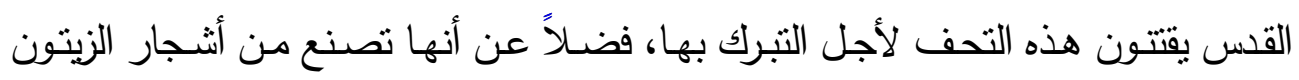

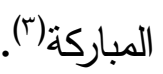

وكانت تصنع أثنياء أخرى في هذه المدينة من أثنجار الزيتون مثل التماثيل التي تمثل

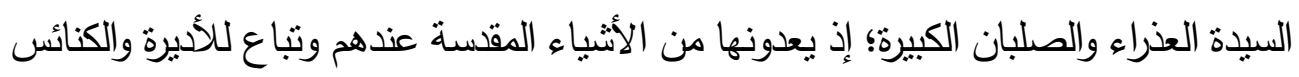
بأسعار عالية(ई).

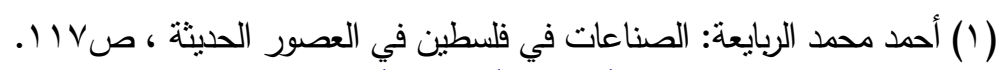

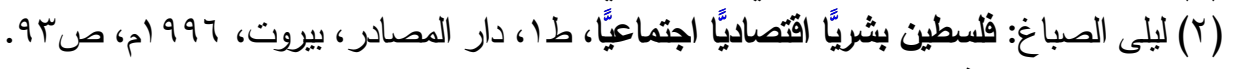

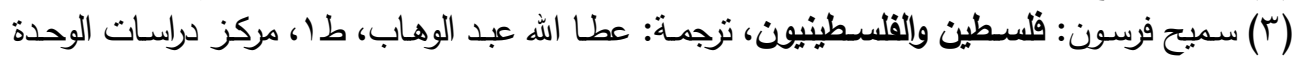

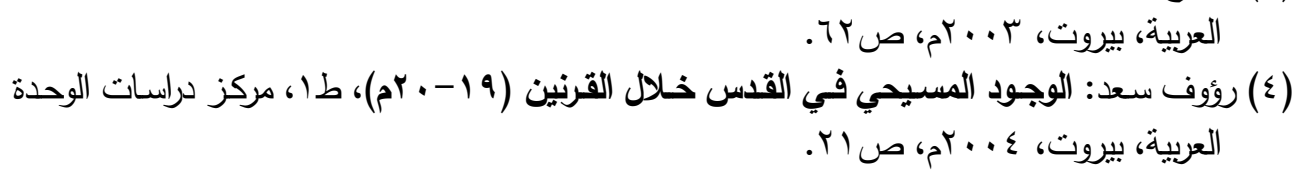




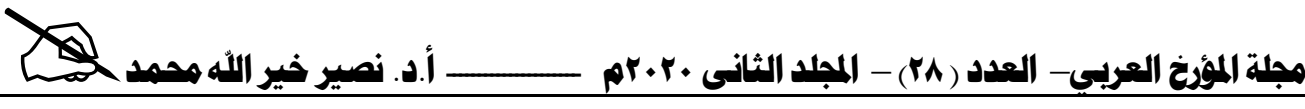

ب - صناعة زيت السمسم واللابس والخمور والززبيب:

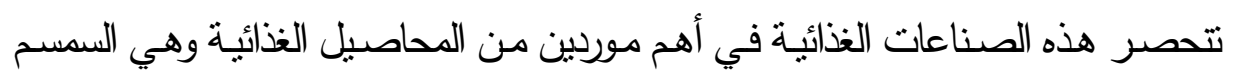
والعنب، ويرتبط بمحصول السمسم عدة صناعات وأهمها زيت السمسم والحلاوة والطحينية، وأن ألنان

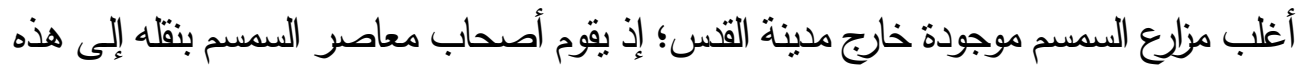

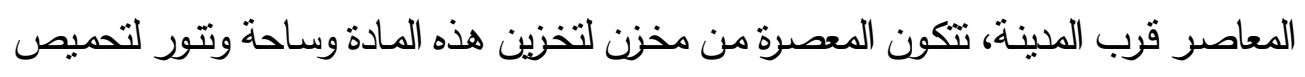

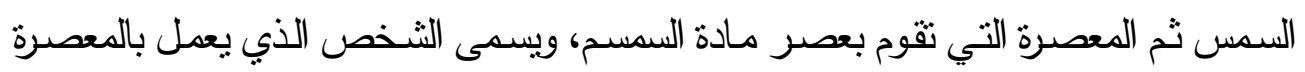

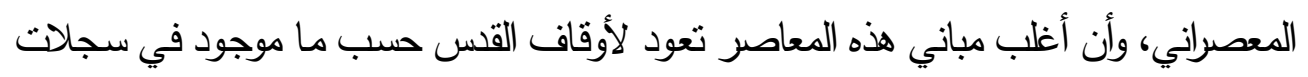

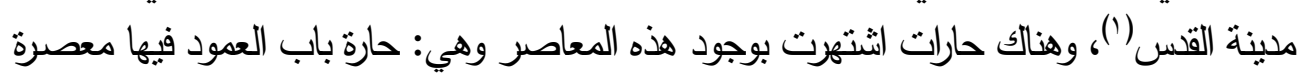

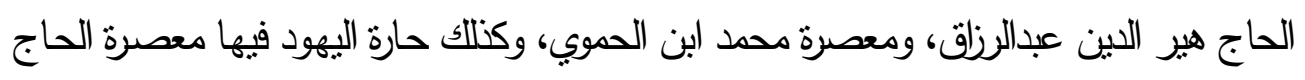
يوسف الققاق، وحارة القطانين فيها معصرة الحاج خليل شيخ طائفة المعاصرية في باب القئ القطانين،

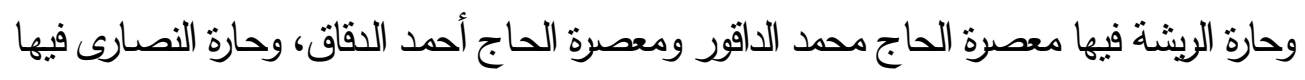

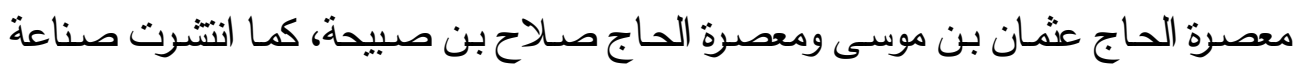

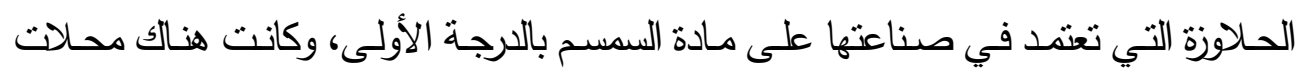

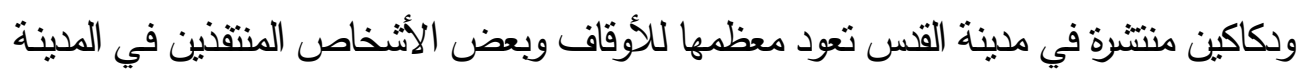

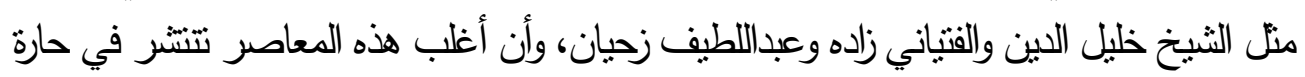

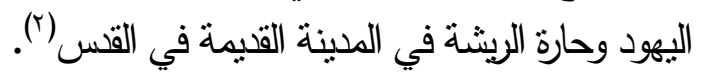

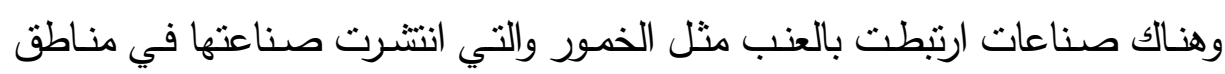

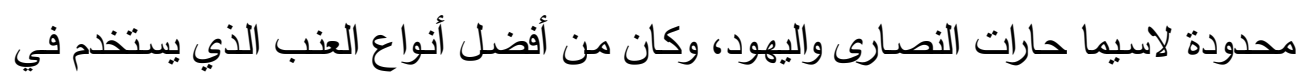

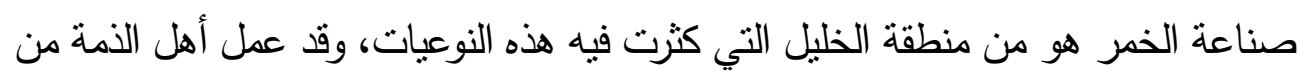

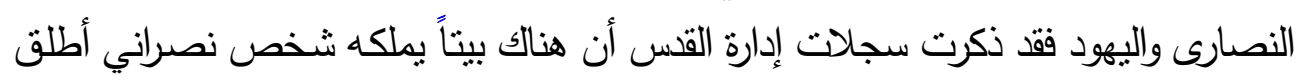

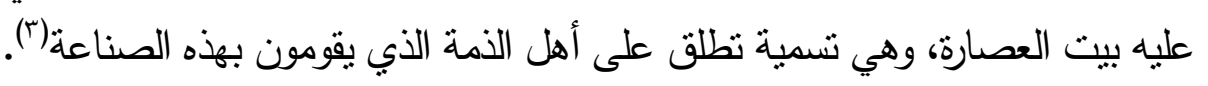

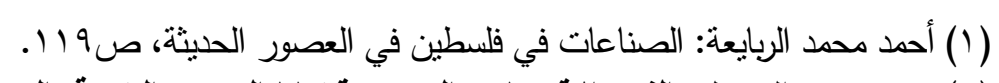

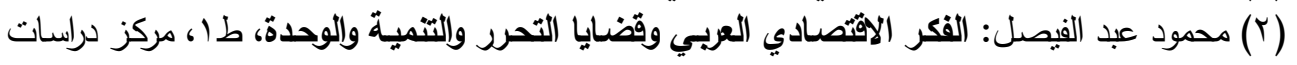

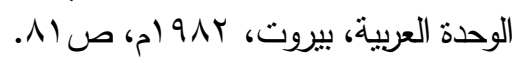

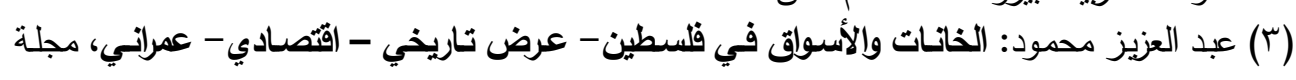

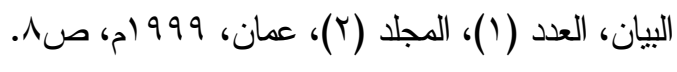




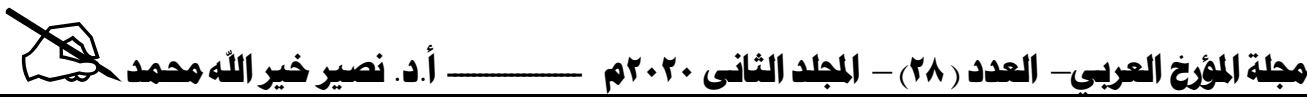

وكنلك اهتم أهل القس بصناعات أخرى مثل الدبس والزبيب، كانت هذه الصناعة قد بدأت في مناطق مختلفة من القرى المجاورة لملينة القس، واعتمدت على العنب لاستخدامه

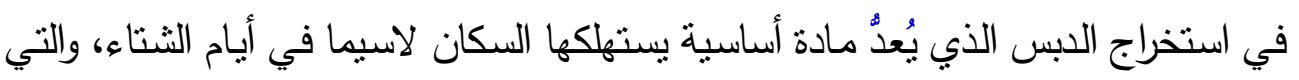

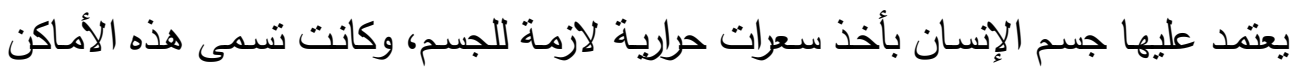

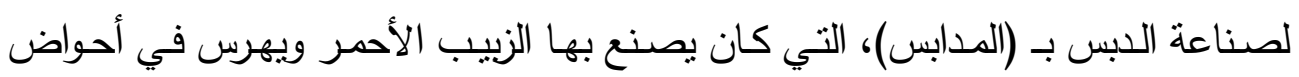

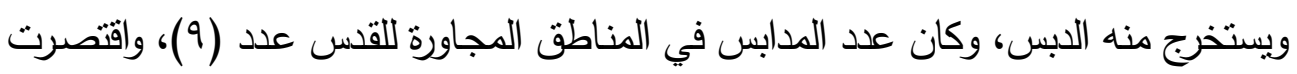

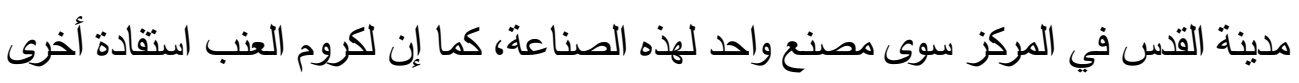

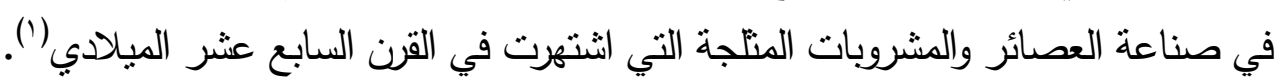

$$
\text { ج - صناعة الحبوب وإلطويات: }
$$

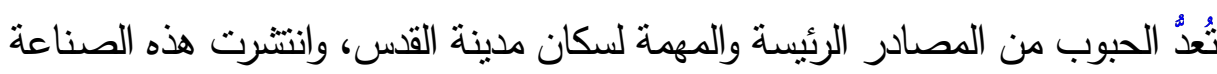
في القس والمدن المجاورة لها، ألا وهي طحن الحبوب لأسيما مادة القمح، التي تُعدُّ عنصرًا

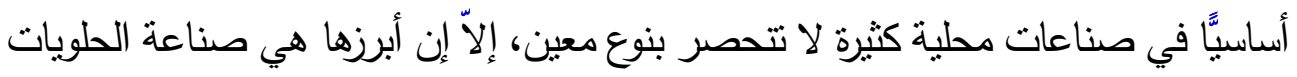

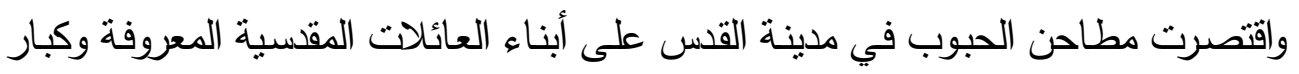

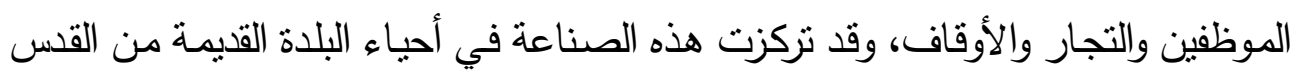

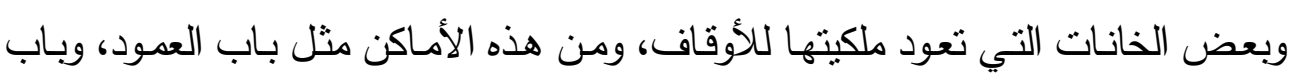

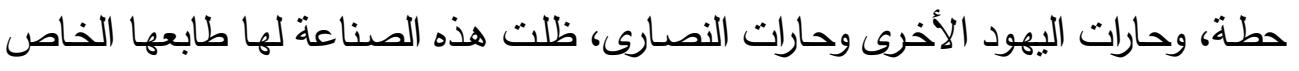

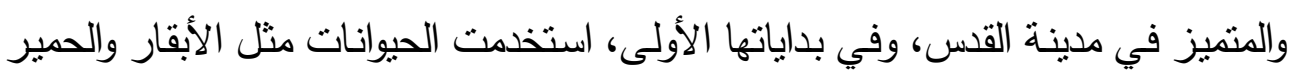

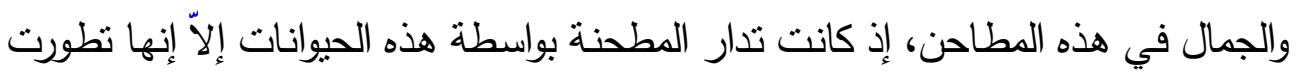

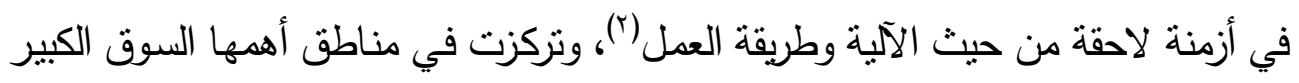

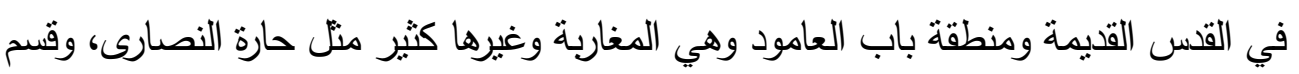

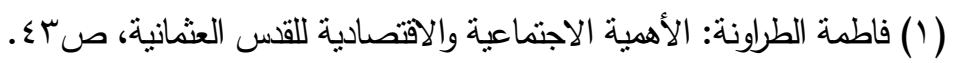

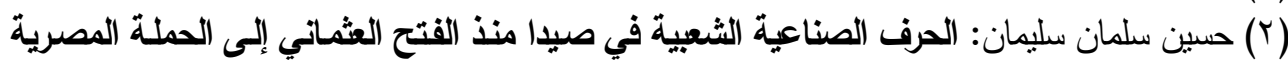

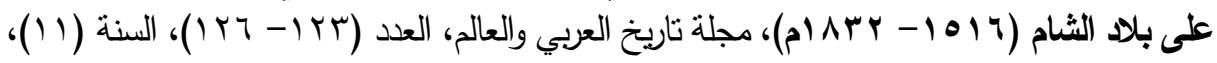




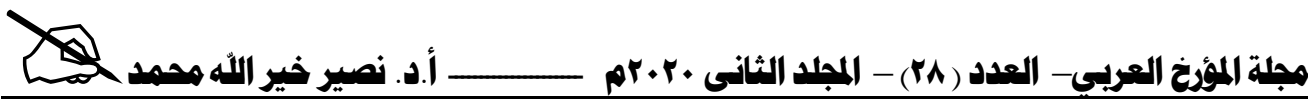

كبير يعود للأوقاف، ومن أنثهر مطاحن المدينة التي بلغ عددها ما يقارب السبعين مطحنة،

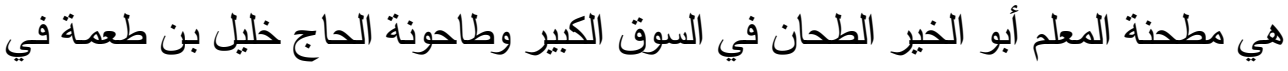
باب العامود، وطاحونة المغاربة في حي المغاربة، وطاحونة القلعة في مركز الدينة قلعة العية

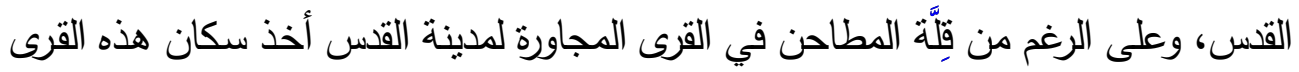
بجلب الحبوب إلى مركز المدينة لغرض طحنها والاستفادة منها لأغراضهم المنزلية، فضلاً

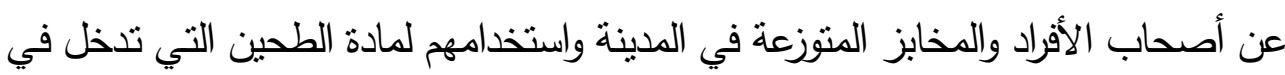
صناعات عليدة) (')

وقد اعتمدت الأفراد والطوابين على مادة الطحين الذي يصنع منه الخبز على اعنباره

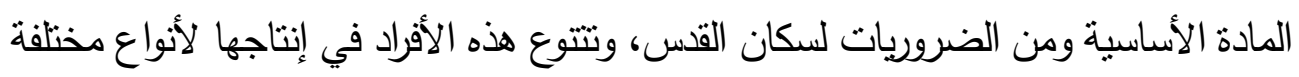

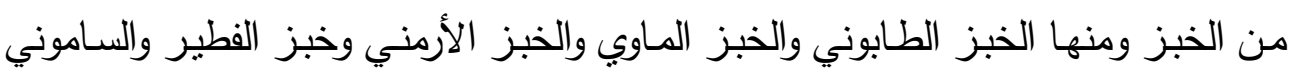

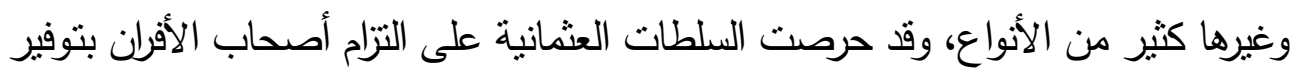

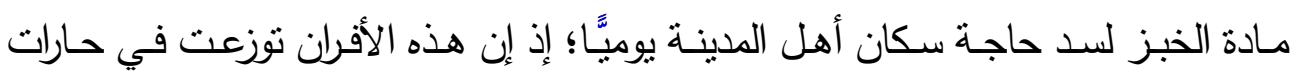

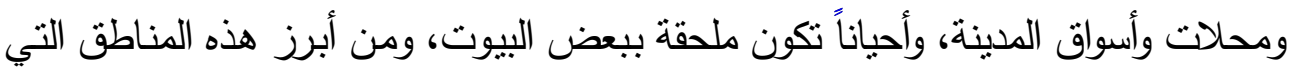

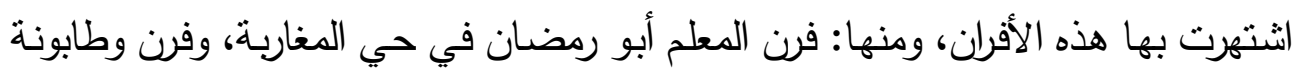

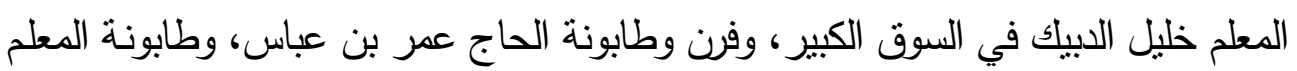

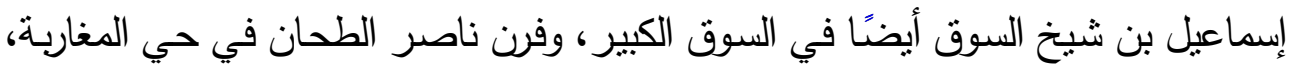

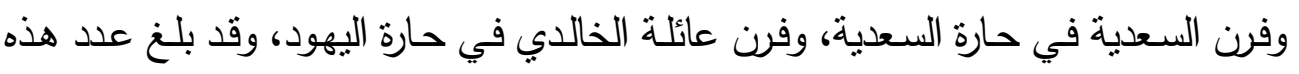

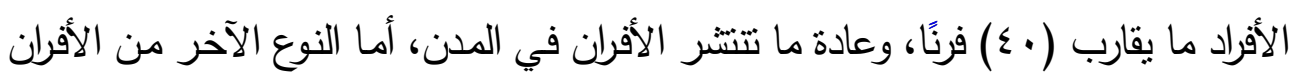

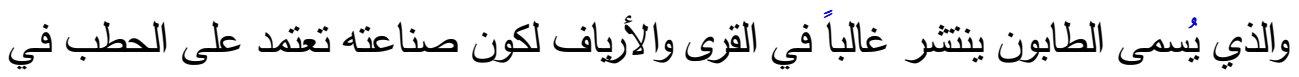

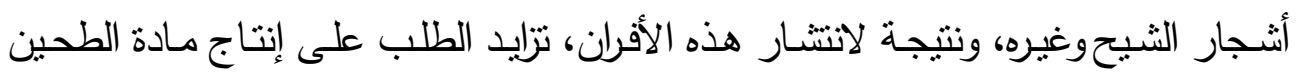
المحلية وتزويد ما بيد الحاجة المحلية لمركز المدينة وأطرافها (؟).

( ) خالد تحسين علي: دراسـات في التتمية والتكامـل الاقتصـادي العربي، مركز دراسـات الوحدة العربية،

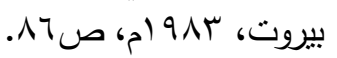

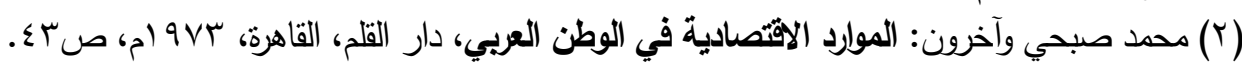


ثانيًا: صناعة الألبسة:

اعتمدت هذه الصناعة في بدايتها على مواد القطن والصوف والكتان، وقد اقتصرت الاعدة

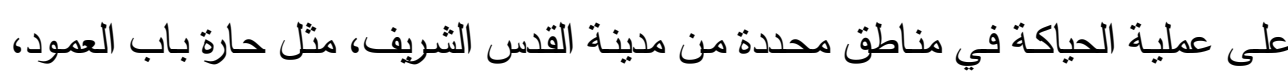

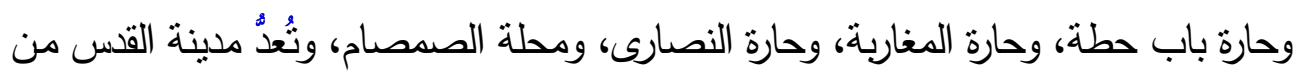

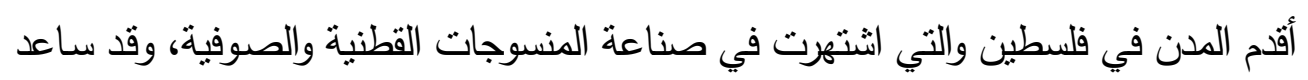

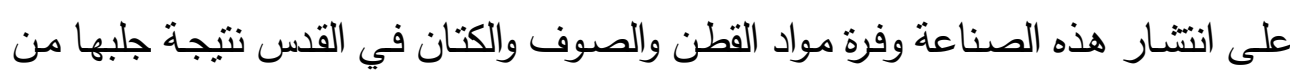

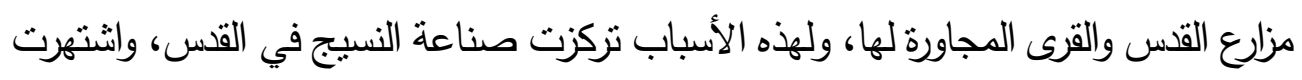

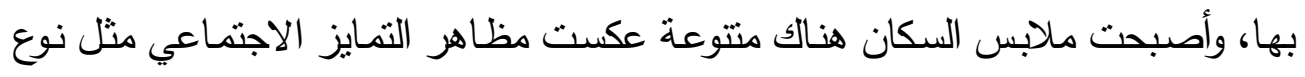

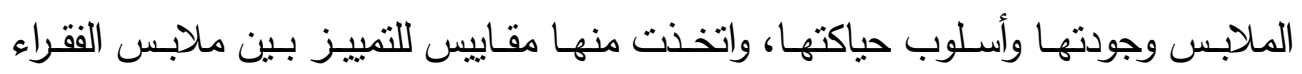

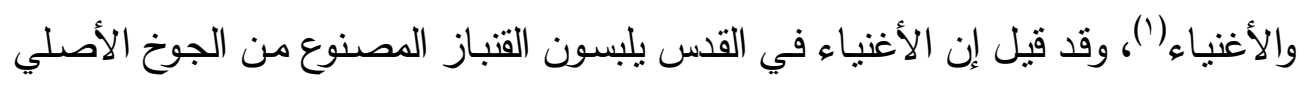

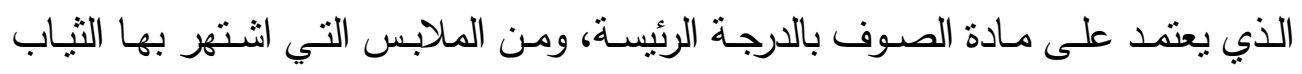

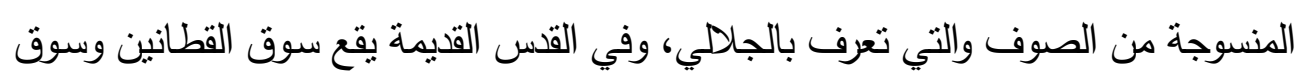

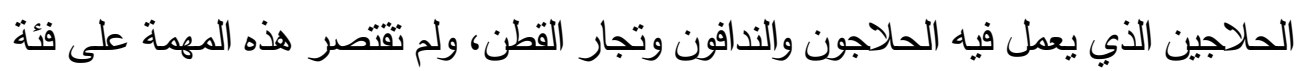

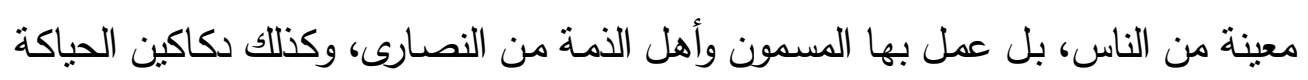

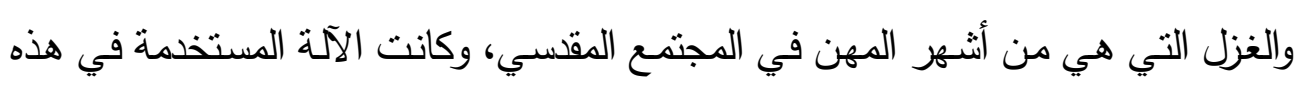

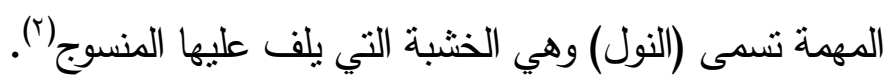

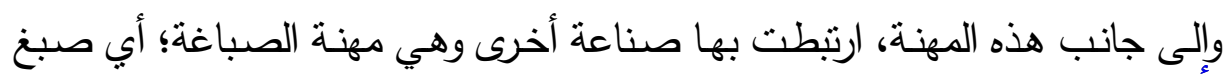

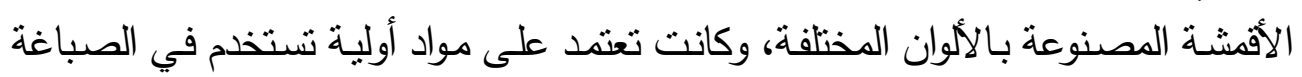

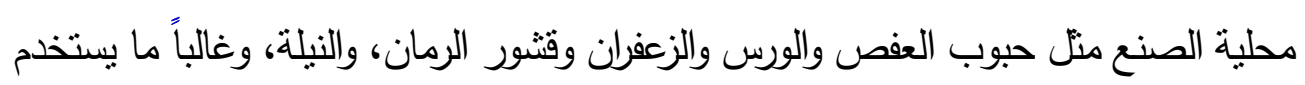

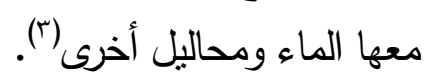

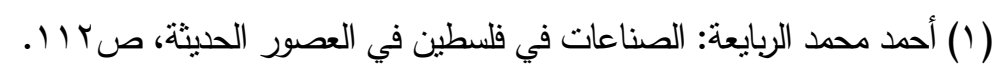

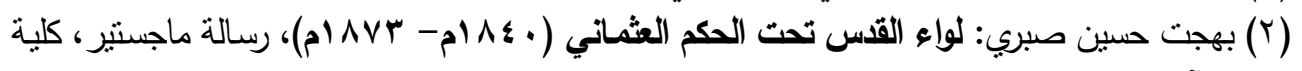

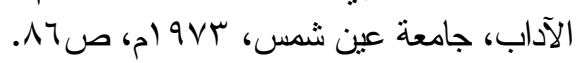

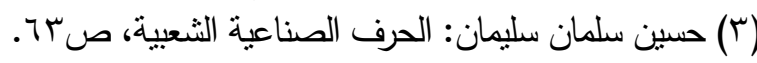




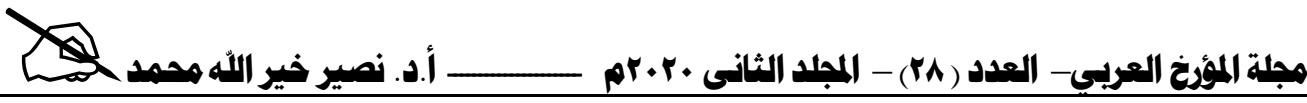

أما الصبغة الرئيسة التي كانت تستخدم في هذه الصناعة ألا وهي صبغة النبلة ذات

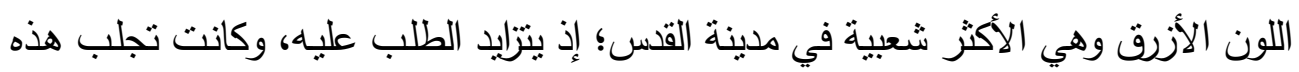

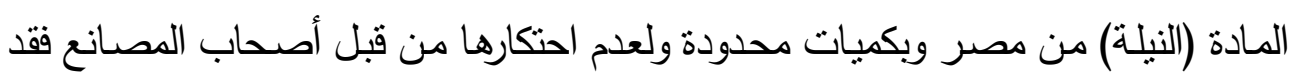

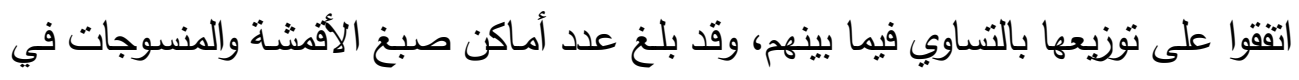

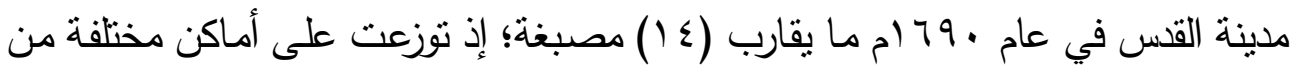

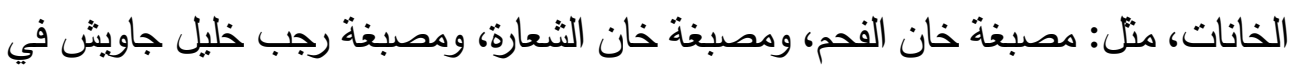
حارة اليهود، ومصبغة زغلول الصباغ (1). لقد كانت هذه المصابغ توفر مجال عمل لأعداد كبيرة من الناس من أهل القدس،

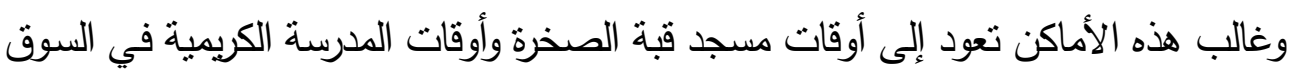

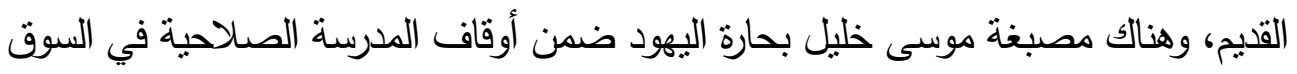

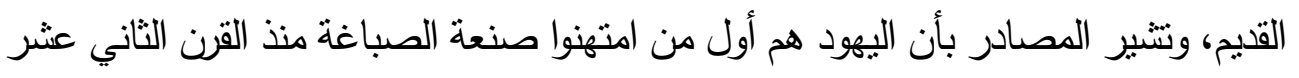

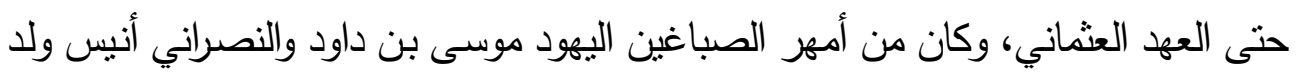

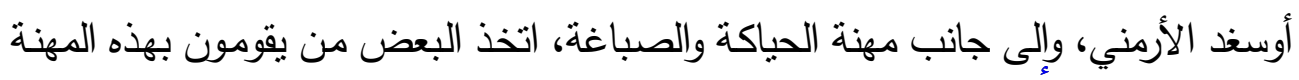

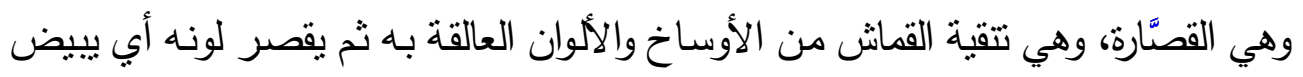

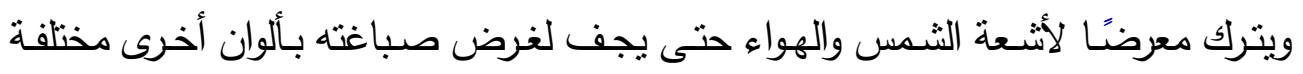

$$
\text { وعرضه في الأسواق(؟) }
$$

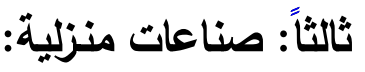

تتوعت النشاطات الاقتصادية في صناعة المواد المنزلية وهي من الحاجات الضرورية

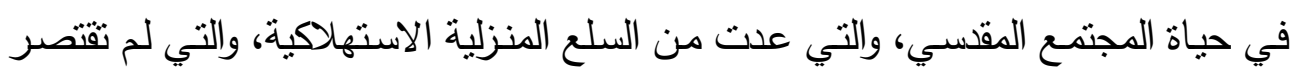

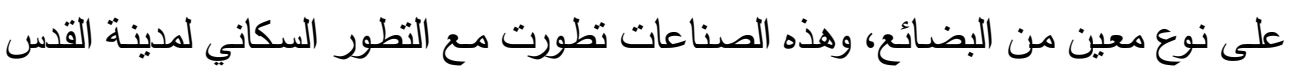
وحسب الحاجة إليها.

(1) (1) حسين سلمان سليمان: الحرف الصناعية الثعبية، صسآ.

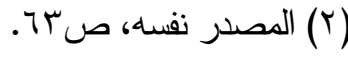


اهـتم سـكان القدس مـن الحرفيين بهذه الصـناعة التي شكلت عنصـرًا مهمَّا ضــن الصناعات التي انتشرت في مدينة القد، وقد استخدم أهالي القدس النحاس في صناعة الأدوات النحاسية والأواني المنزلية منل الصحون والصواني النحاسية وحلل الماء التي تنتخدم في الحمامات، كما استخدم النحاس في صناعة القدور التي تستخدم كأواني طبخ عامة والتي

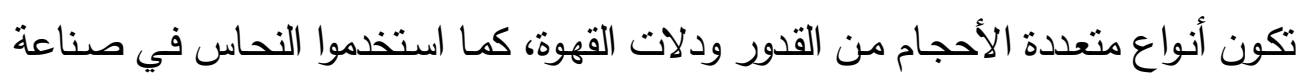
الأواني الكبيرة التي تستخدم في الصناعات المحلية في المعامل الصغيرة، كمعامل الصابون والمعاصر التي انتشرت في هذه المدينة، كما اثتهر البعض من سكان القدس بمهنة النقش والطرق على النحاس والزخرفة، بأثنكال مختلفة على النحاس، وإلى جانب هؤلاء النحاسين، وجلت مهنة ترتبط بصناعة النحاس وهي تنييض النحاس، وسُميَّت بطائفة المبيضين الذين

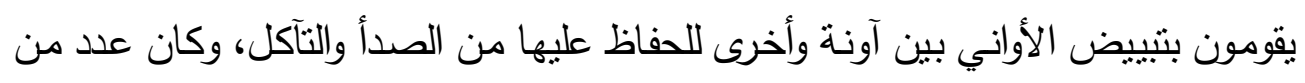

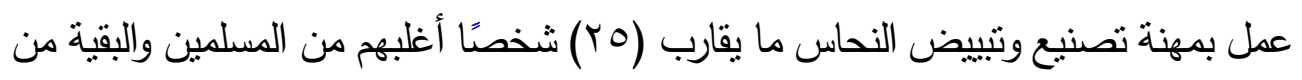

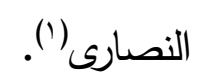

وهناك حِرَف أخرى مهمة ارتبطت بصناعة المعادن، وهي صياغة الذهب والفضة، ومن أكثز ما اثتهر بها من أهالي القدس هم اليهود والنصارى الذين اهتموا بإنتاج نماذج مختلفة

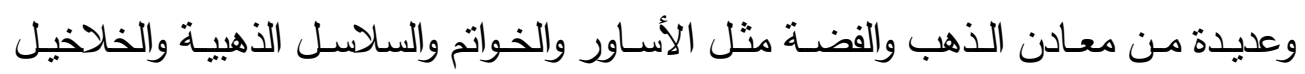
والأقراط، وقد امتهن هذه الصنعة عدد محدود في مدينة القدس، إلاّ إن هناك من اثتهر بها على وجه الخصوص، وهم: عيسى جرجيس النصراني وحاييم خضر من اليهود، وكانت لهم دكاكين في المدينة القديمة في القدس تعود ملكيتها لأوقاف قبة الصخرة، ومن المعروف وهأن صياغة مدينة القدس هي من أفضل ما تم صناعته، وقد اشتهرت بذلك (؟).

( ) عبدالكريم رافق: مظاهر التطليم الحربي في بلاد الثام في العهز العثاني، مجلة دراسات تاريخية، جامعة

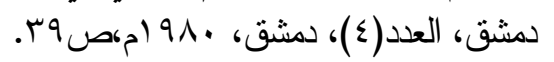

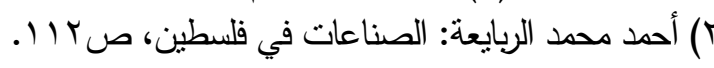




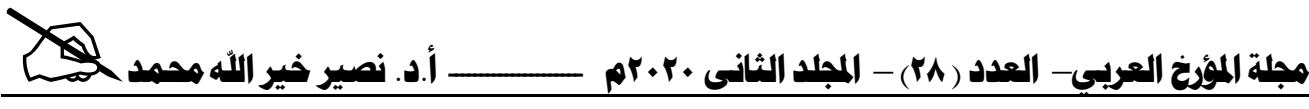

ومـن الصـناعات الأخرى التي اهنت بها أهـالي مدينة القس والتي لها علاقة بالتعلين الصناعات الحيلية كصناعة السيوف والسكاكين والخناجر ، وهناك جانب آخر وهو صناعة الثبابيك والأبواب التي لها علاقة في عملية البناء للمنازل وغيرها ، كما اهتم بصناعة الأغراض الزراعية منل المحاريث والمجاريف والفأس، فضلاً عن صناعة أواني وخزانات كبيرة نتعلق بخزن لهن

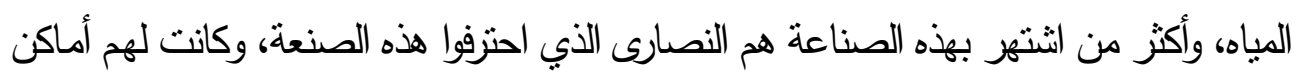

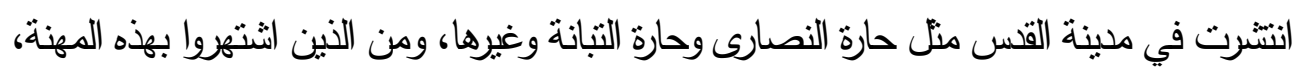

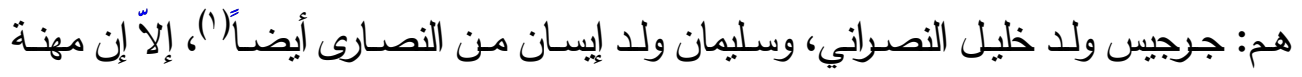
السيوف والسكاكين اختص بها صناع مسلمون مثل درويش بن إبراهيم السيوفي، وهذه الصناعة

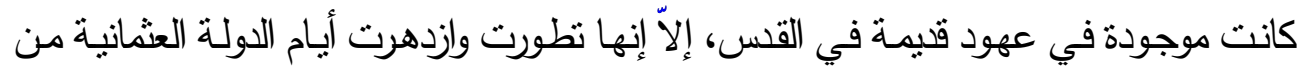
خلال نقل الخبرات الصناعية والعمرانية وتطويرها في مدينة القس، والتي اتخنت طابعًا إسلاميًّا في الغالب من خلا الزخارف والفن العمراني المزوج بالأوروبي (؟).

\section{ب - الصناعات الفخارية:}

اشتتهرت مدينة القدس في الصناعات الفخارية والتي كانت تنتخدم لأغراض متعددة في

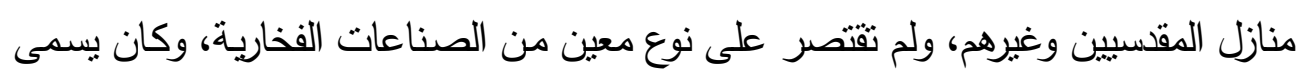

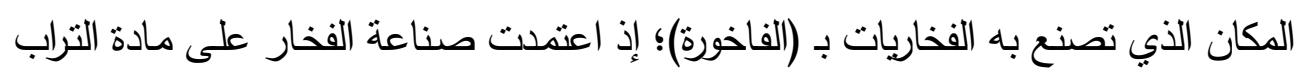
وهو من نوعيات خاصة تستعمل في هذه الصناعة، وكان يصنع منه الصحون والمعاجن

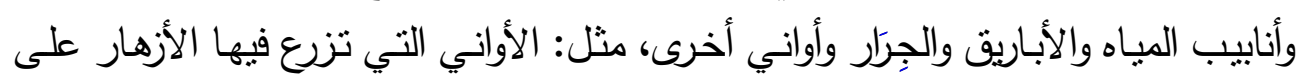

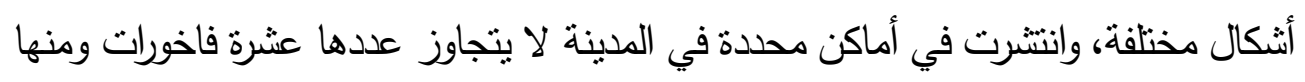

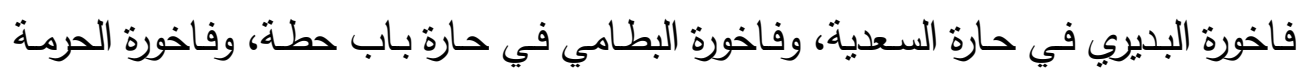

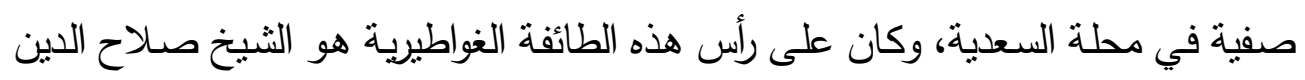
محمد الفاخوري، وهذه الألقاب جاءت نسبة إلى الصنعة التي يزاولونها؟َ).

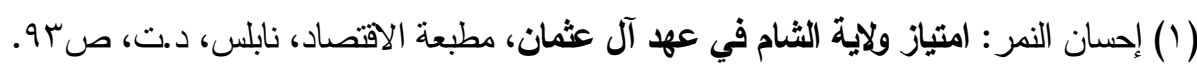

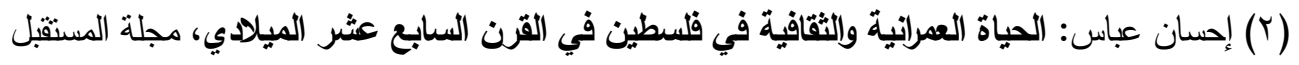

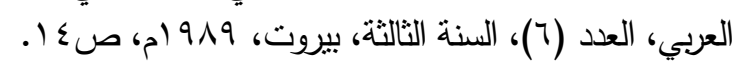

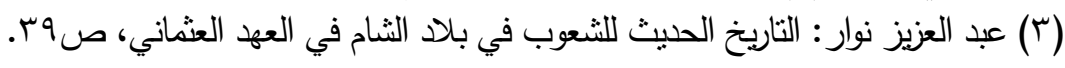




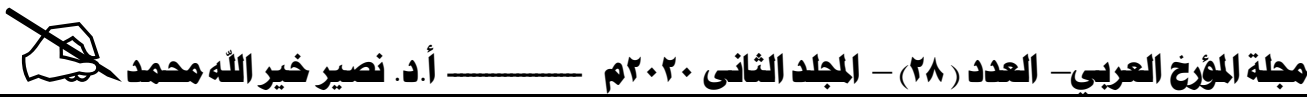

ومن الماحظ أن مدينة القس اثتتهرت بصناعة الفخار القانشاني، وهي عبارة عن ألواح

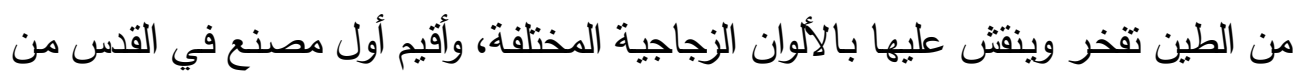

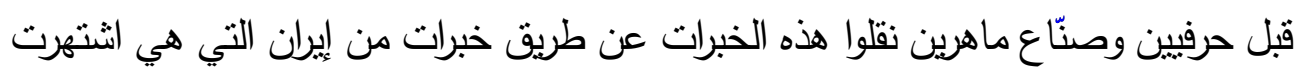

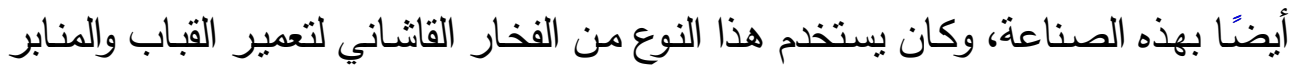

والواجهات في المسجد الأفصى ومسجد قبة الصخرة، ومساجد مدينة القس الأخرى (ل).

\section{ج - كناعة الثمع:}

كانت هذه الصناعة من الجرف التي عدّها المقدسيين من الصناعات المهـة فئة في

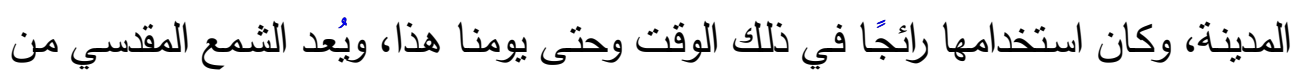

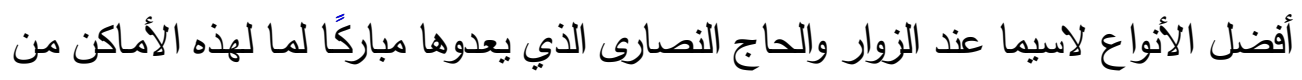

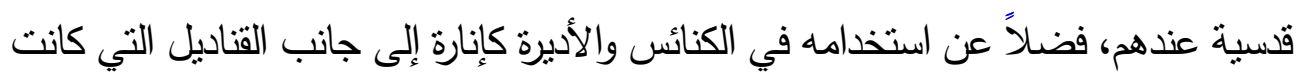

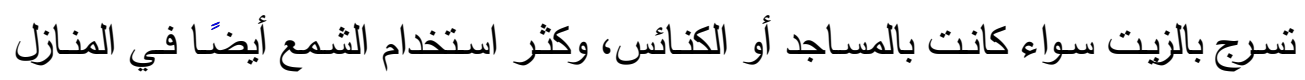

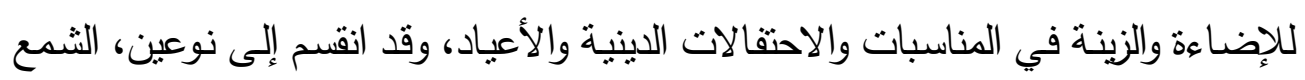

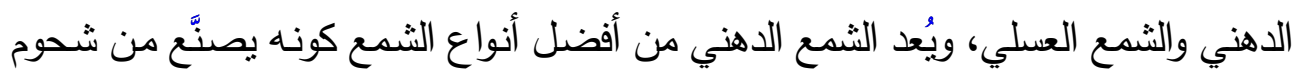

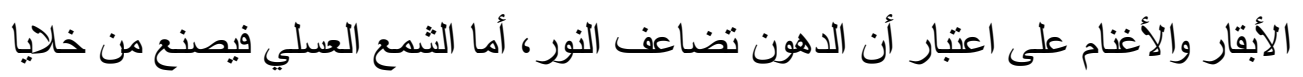
النحل التي كانت تنتشر في مدينة القس أيضًا (؟).

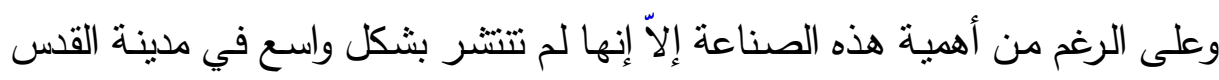
سوى شماعتين في المدينة وسط السوق القديم في القدس، كان يملكها صناع نصارى وهم:

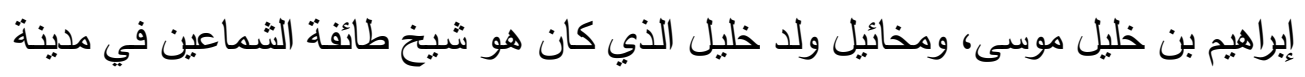

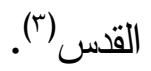

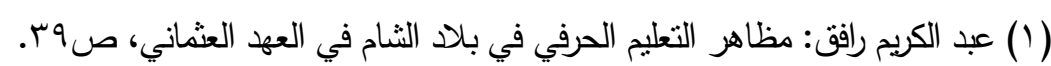

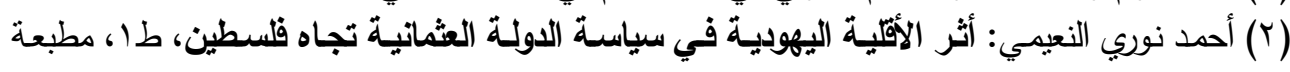

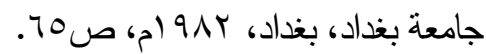

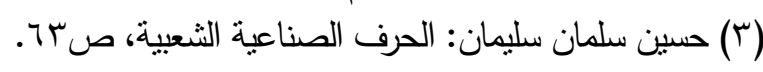




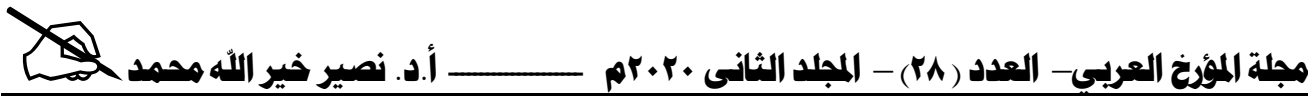

د - مناعة الجلود:

اعتمد صناعة الجلوس بالدرجة الأساس على الثزوة الحيوانية التي اهتم بها أهالي القدس

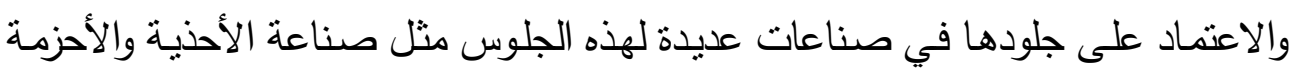

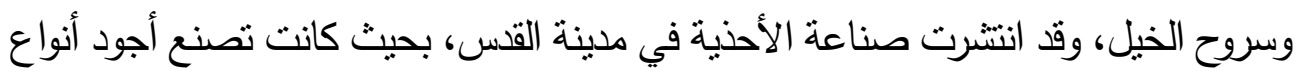

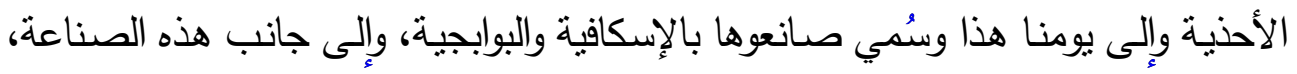

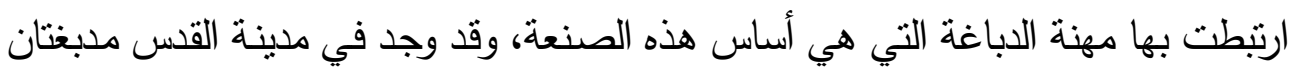

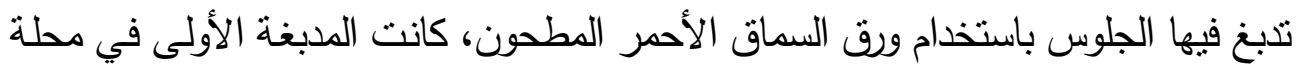

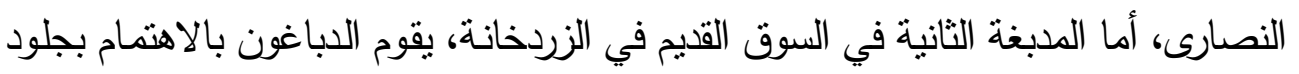

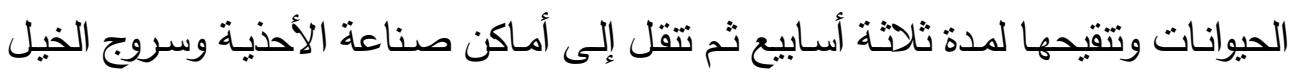

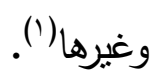

أما سروج الخيل اقتصرت صناعتها على عناصر رومية لاسيما في عام 1000 م، ككان

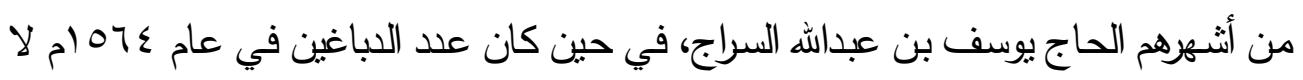

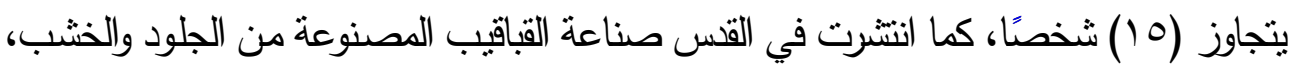

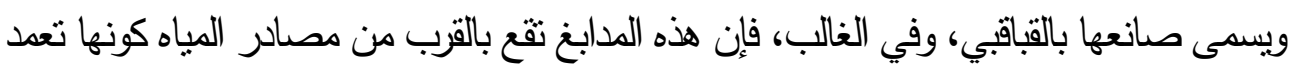

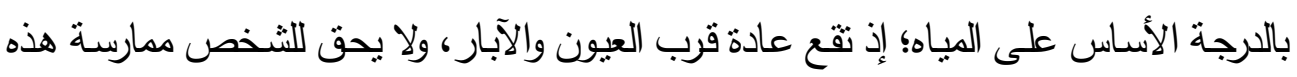

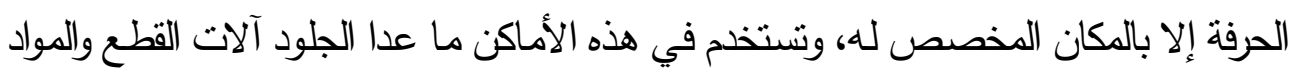

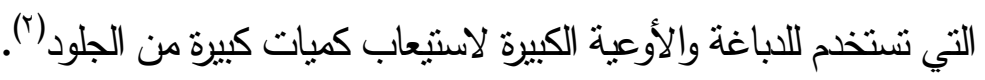

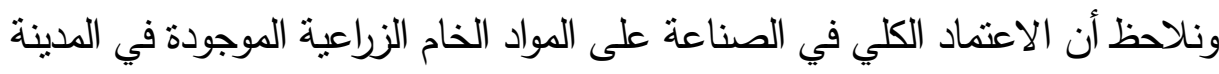

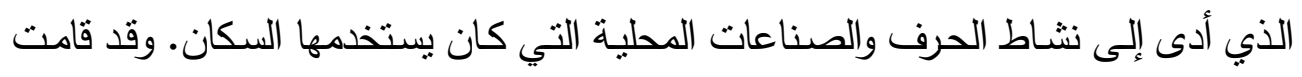

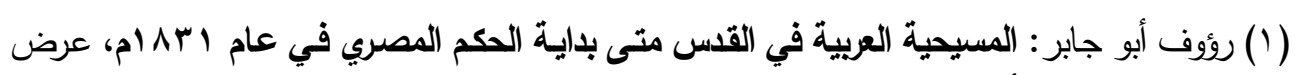

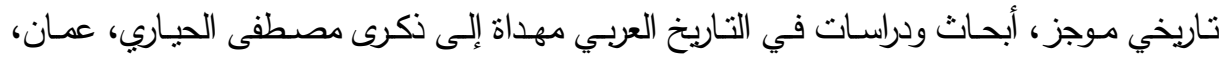
(Y)

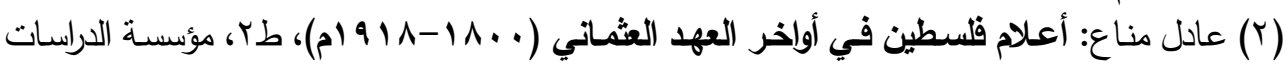

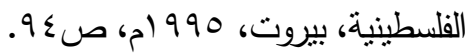




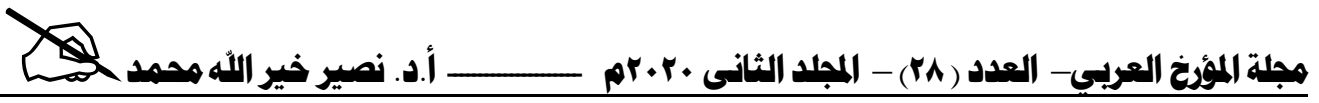

الصناعات المختلفة من أجل سد الحاجة المحلية للسكان كصناعة الملابس أو المواد الغذائية والمنظفات؛ وذلك بالاعتماد على الموجود في المدينة من مواد خام. المبحث الثالث: التجارة

تعد التجارة في مدينة القس هي من أهم الجوانب الاقتصادية، وهي عصب الجباة الحياة

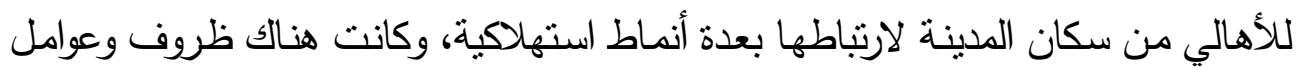

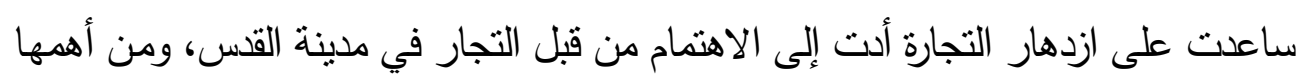

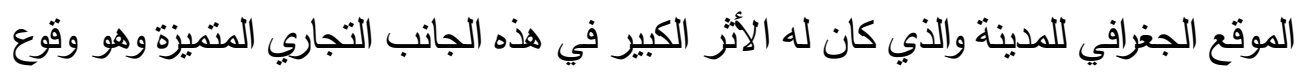

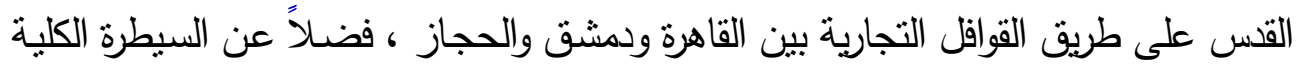

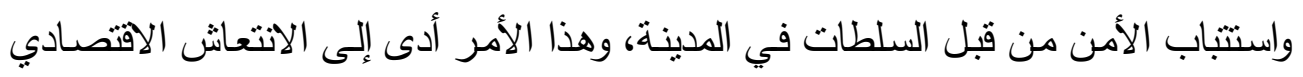

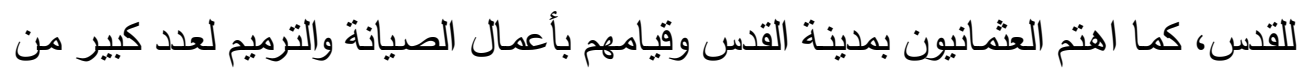

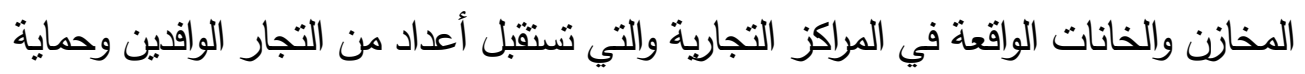

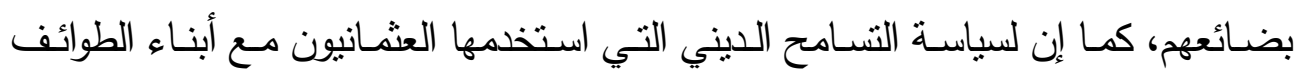

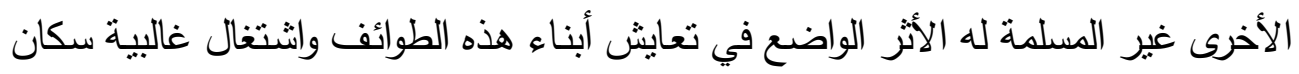

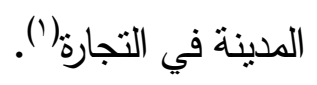
أولاً: التجارية الاخلية في القسب:

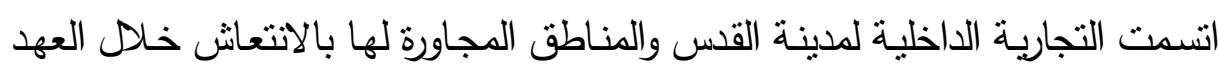

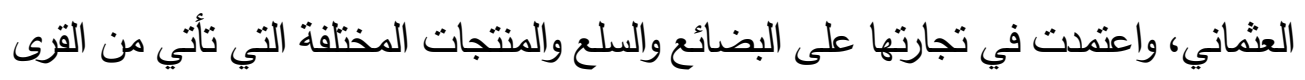

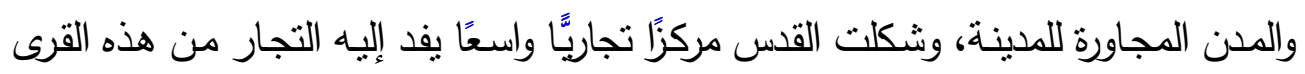

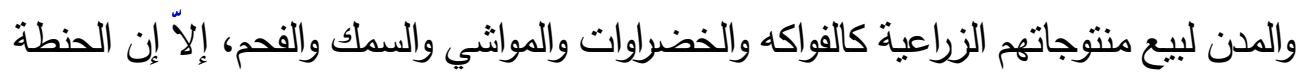

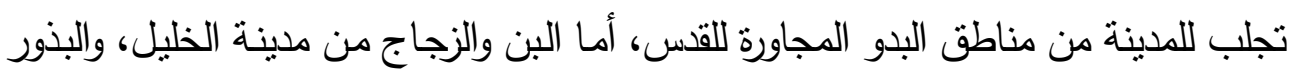

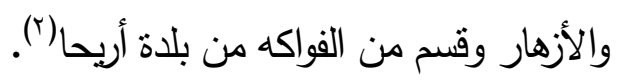

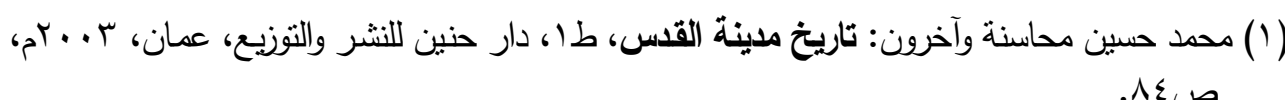
(r) سميح فرسون: فلسطين والفلسطينيون، ص זT. 


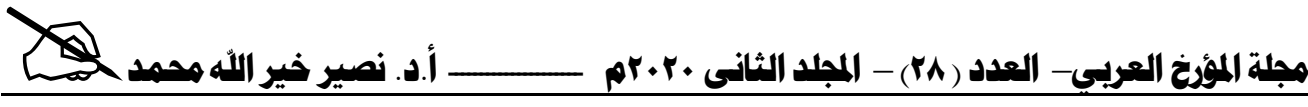

وهناك أنواع مختلفة من البضائع والسلع المحلية تتوفر في أسواق القس مثل زيت الزيتون

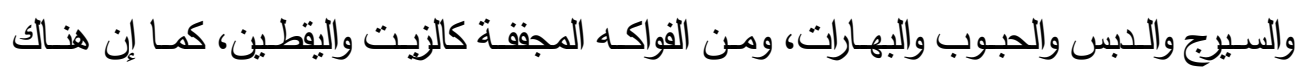

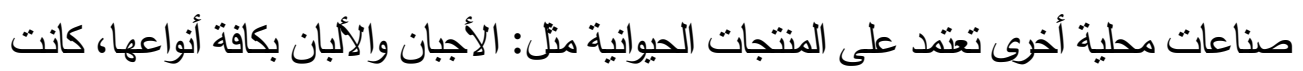

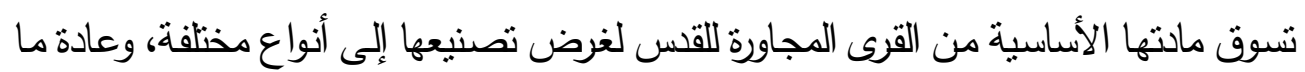

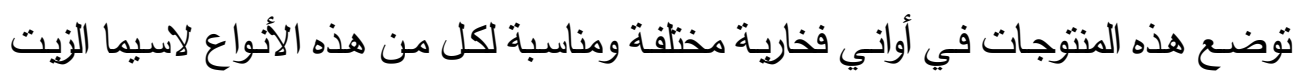

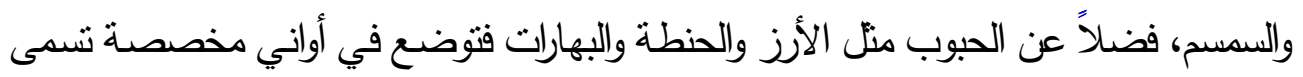

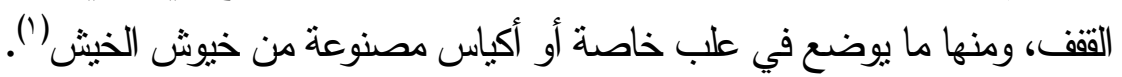

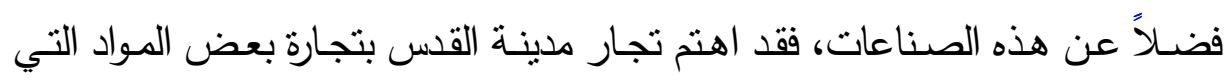

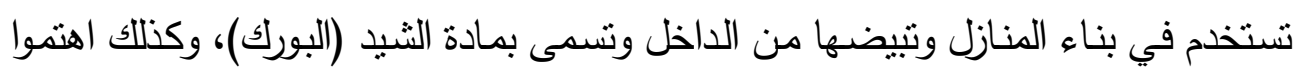

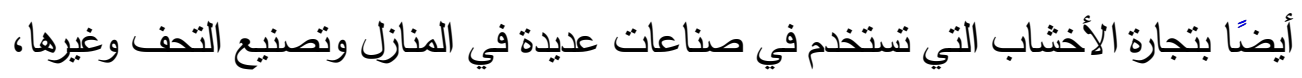

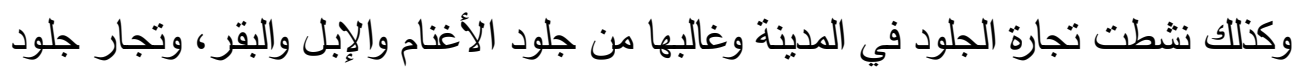
الماعز والجواميس لحاجة صناعة الأحذية إليها (r).

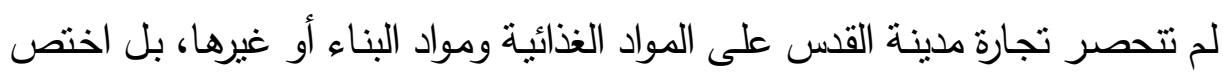

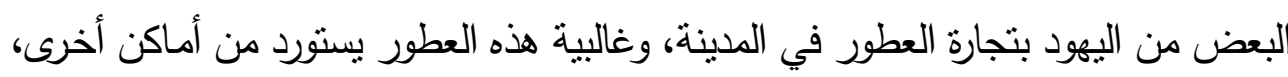

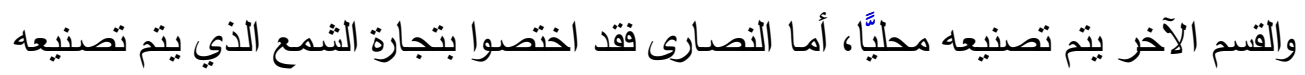

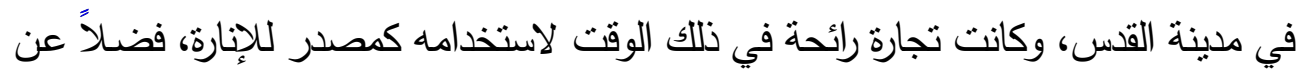

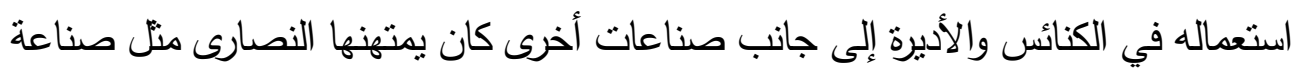

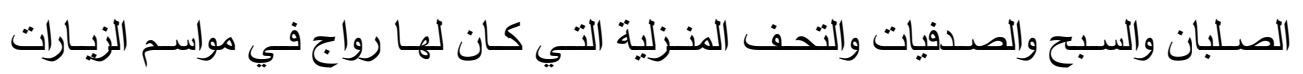

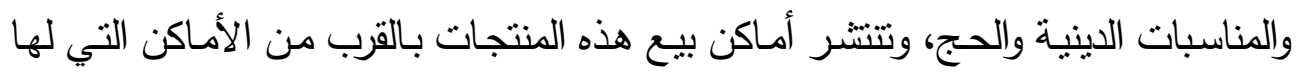
قسية سواء كانت للمسلمين أو النصارى أو اليهود منل الدكاكين والمحال البدائية(†).

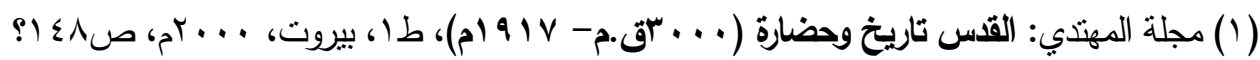
(r) حيبب السيوفي: سوريا ولبنان وفلسطين في القرن الثامن عثر كما وصفها مثاهير الغربيين، (د.ن)،

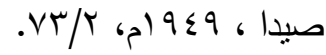

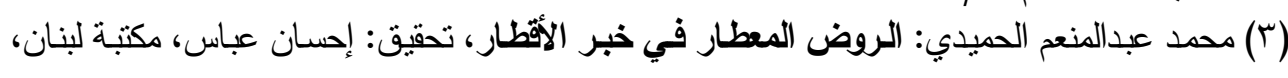

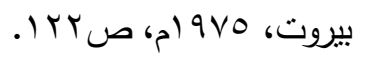




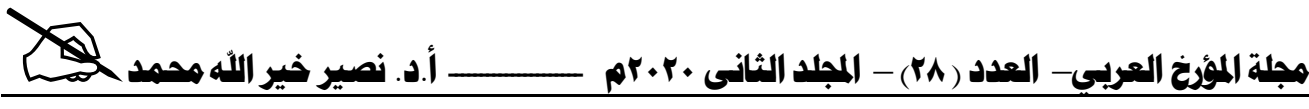

وقد تبيّن من خلال حجم النشاط التجاري الداخلي لأهالي مدينة القس بأن تلك الأسواق

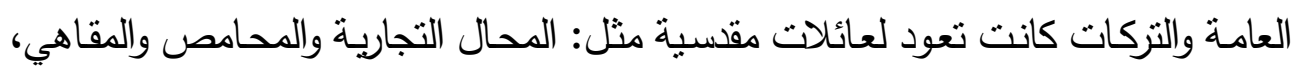

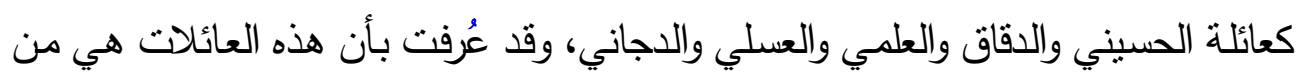

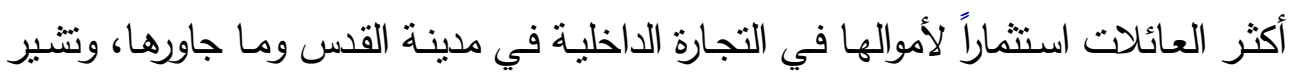

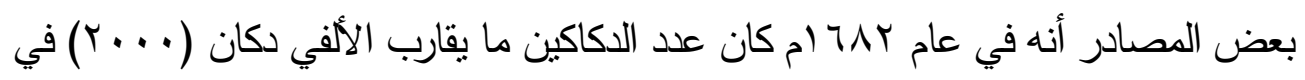
القسس كلها مبنية من الحجارة والعقود المقنطرة، توزعت هذه المحان المال إلى الى عدة أسواق، ومنها:

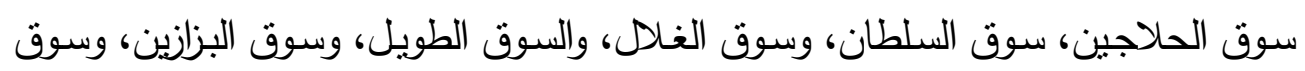

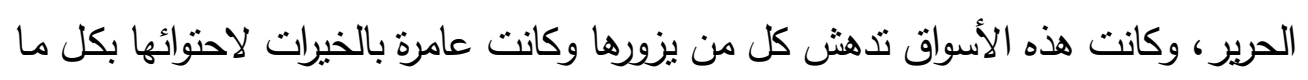

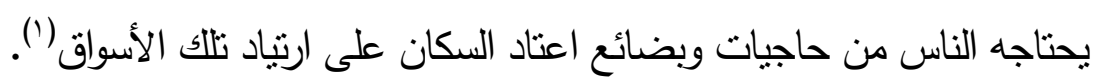

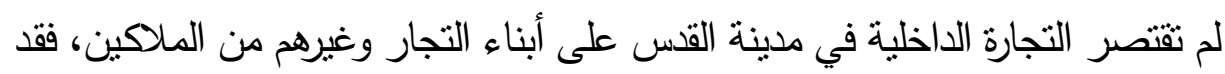

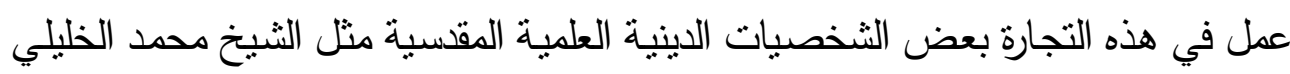

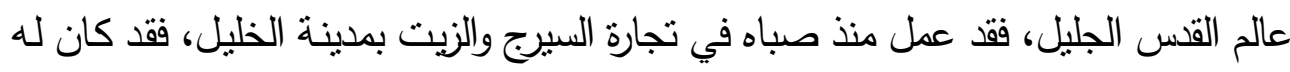

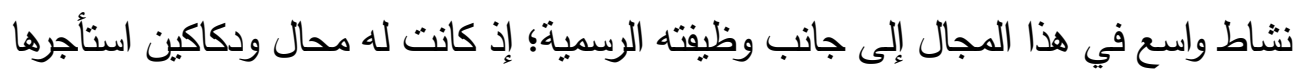

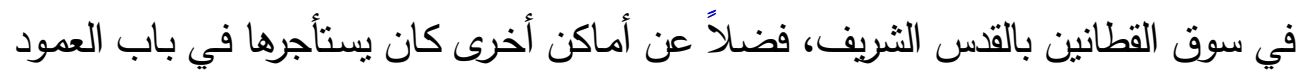

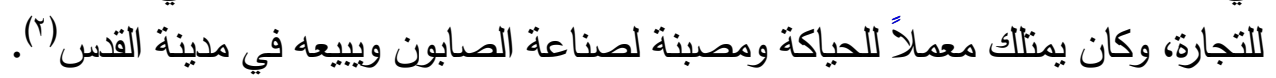

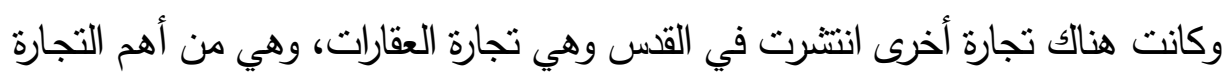

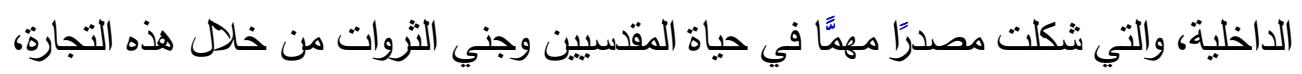

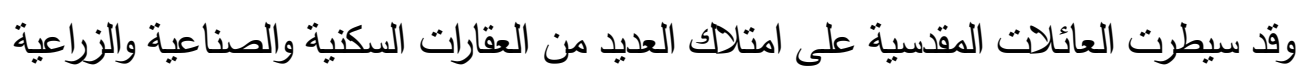

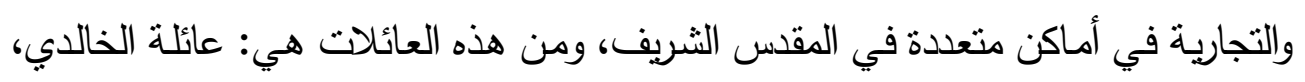

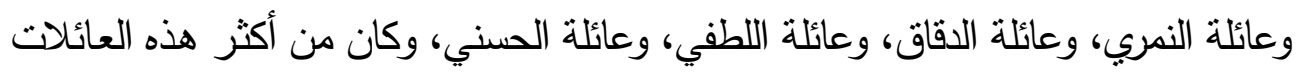

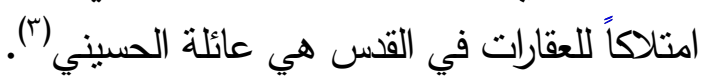

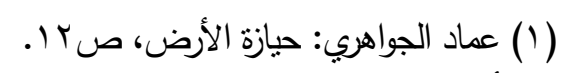

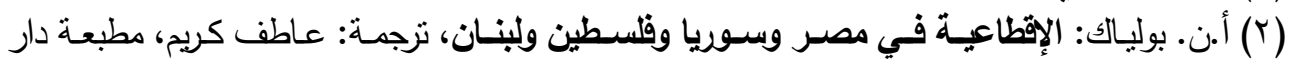

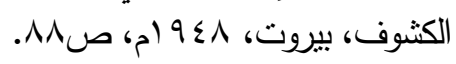

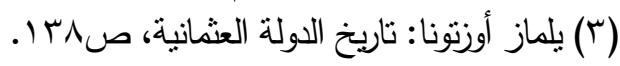




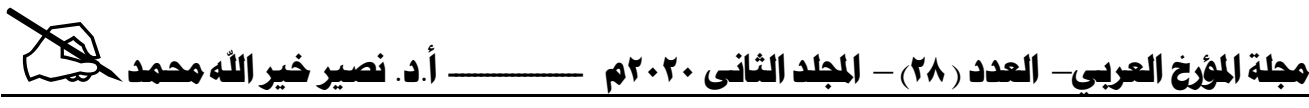

وقد اختلفت هذه العقارات من حيث أسعارها، فكانت أسعار العقارات الصناعية أعلى من

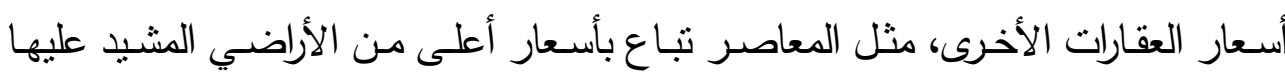

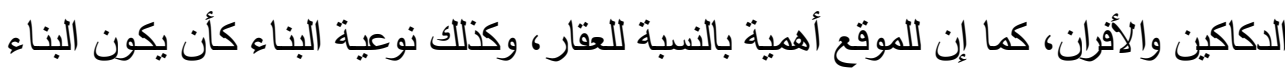

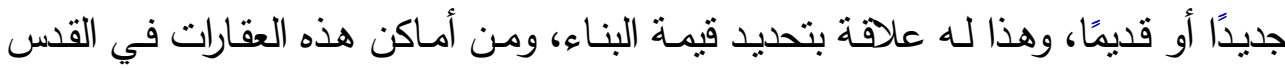

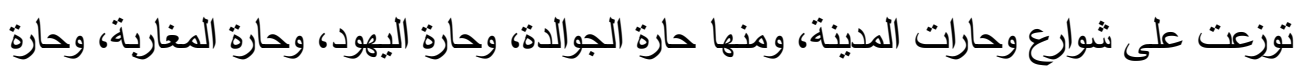

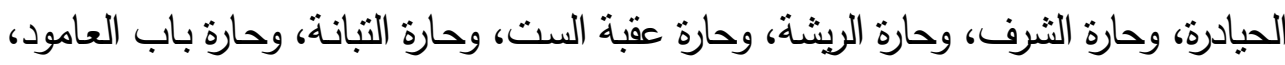

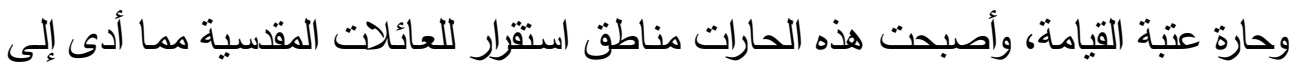

$$
\text { ارتفاع أسعارها ('). }
$$

\section{ثانيًا: التجارة الخارجية للقسن:}

لم تتحصر التجارة في مدينة القس في العهد العثماني على التجارة الداخلية فقط، وإنما كان لتجارة القس الخارجية نثاط فعال، لاسيما في استيراد وتصدير البضائع، وقد ازدهرت

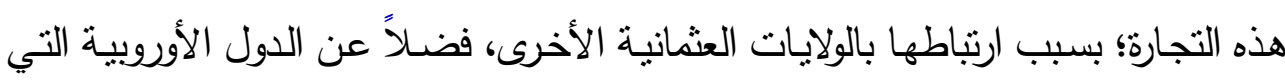

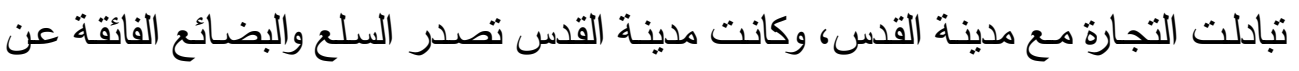

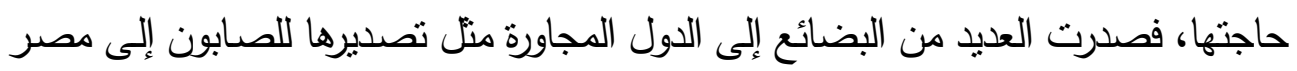

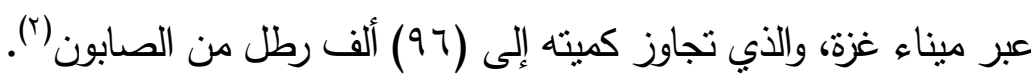

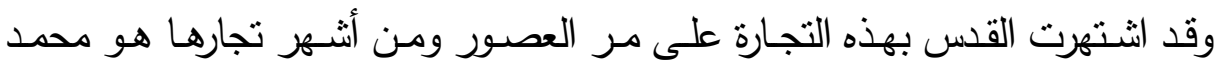

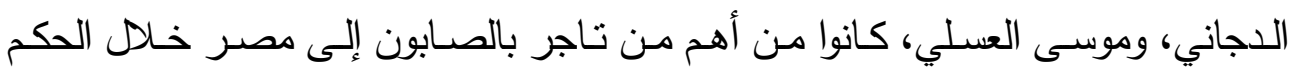

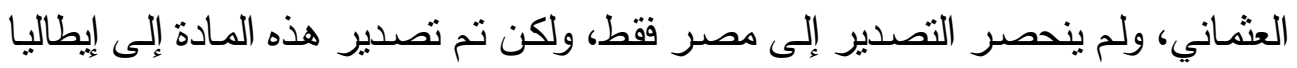
واليونان، كون الصابون المقسي كانت له شهرة في بعض البلاد الأوروبية(؟).

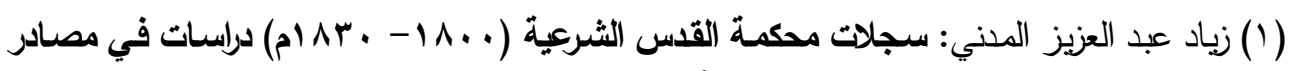

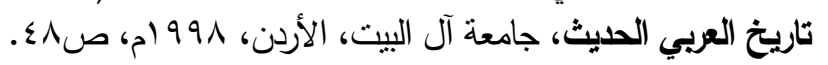

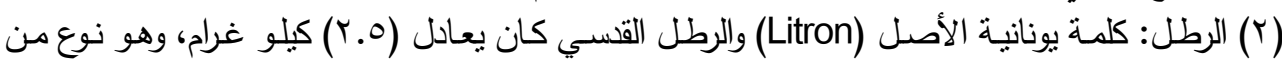

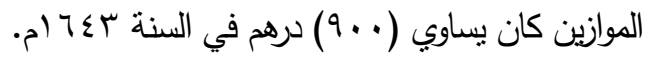

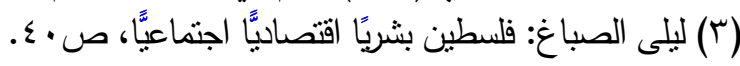




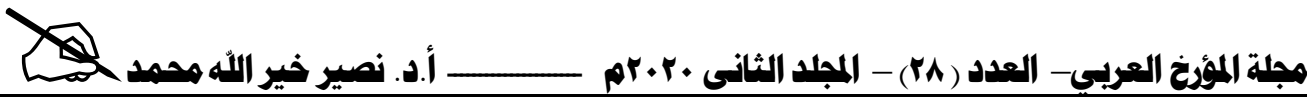

كنلك اهتم تجار مدينة القس الثرريف بتجارة الحبوب الخارجية إلى الدول المجاورة مثل

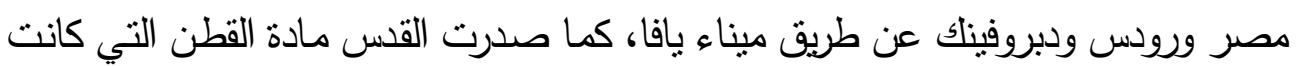

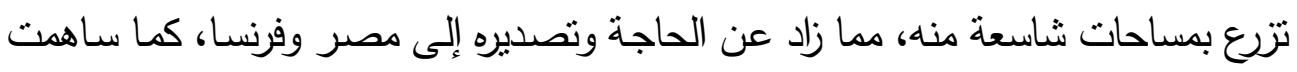

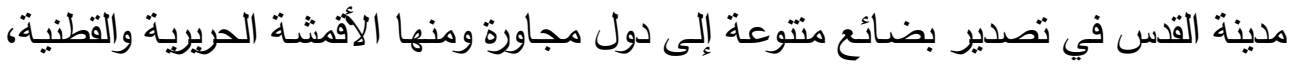
والصمغ العربي، والبن، والسنامكي وهو من النباتات العشبية التي تتكاثز في مدينة القدس وله فئه

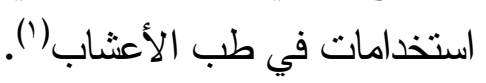
ومن البضائع الأخرى التي كانت تصدرها القدس إلى استانبول وإيطاليا والبرتغال وإسبانيا

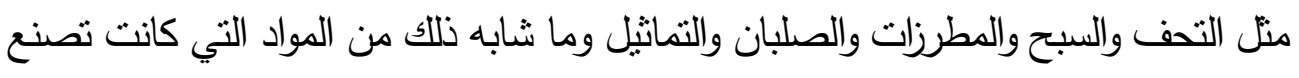

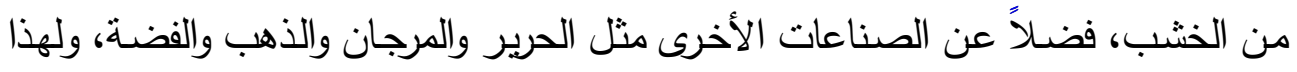

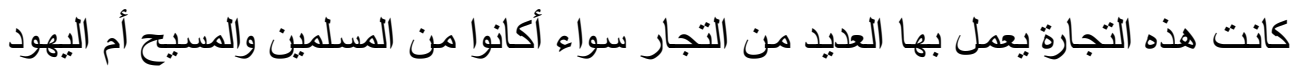

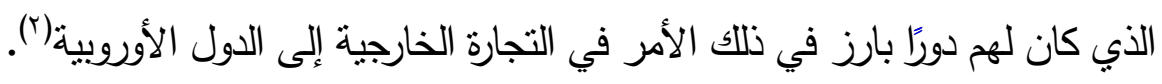

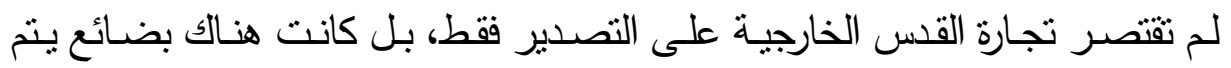

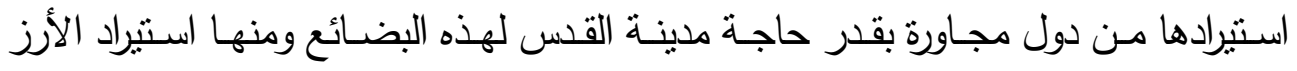

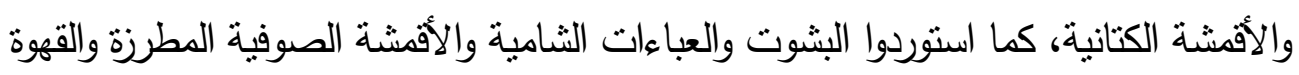

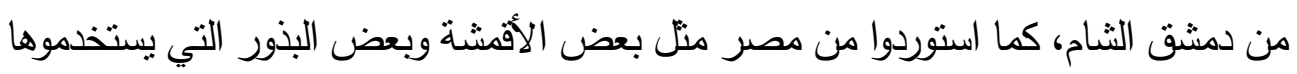

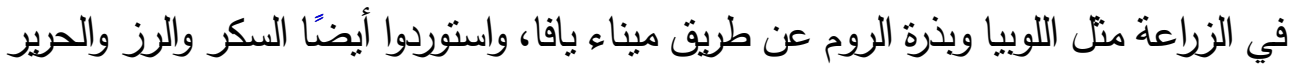

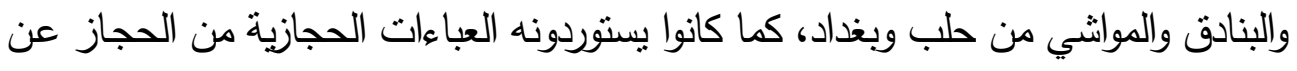

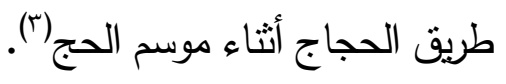

( (1) محمود علي عطا اله: وثائق الطوائف الحريـة في القدس في القرن السـابع عثر الميلادي، طب،

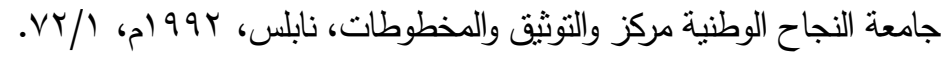

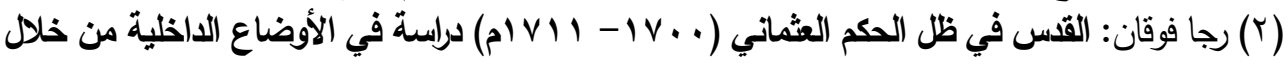
سجلات المحكمة الثرية في القدس، مجلة مؤتة للبحوث والدراسات العلوم الإنسانية والاجتماعية،

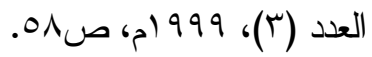

$$
\begin{aligned}
& \text { (r) ليلى الصباغ، فلسطين بشرياً اقتصادياً اجتماعياً، ص • ؛. } \\
& \text { - MIN - }
\end{aligned}
$$




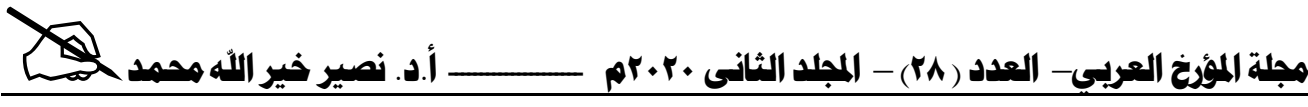

ومن البضائع والسلع الأخرى التي استوردها من الهند مثل الثنالات وبعض الأفمشة

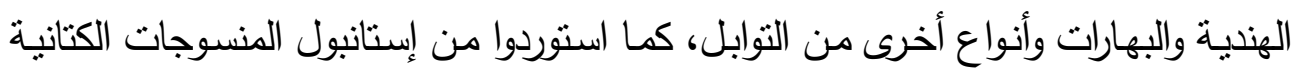

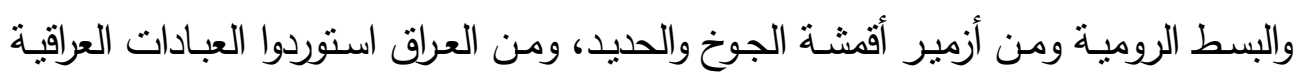

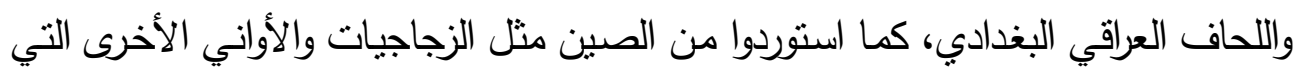

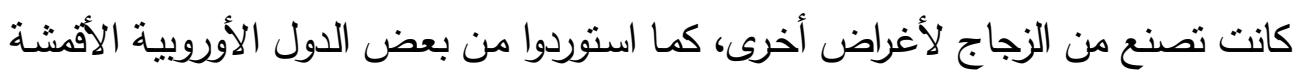

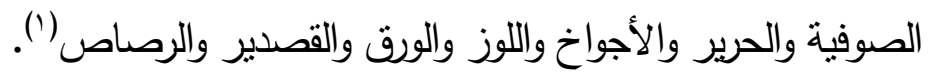

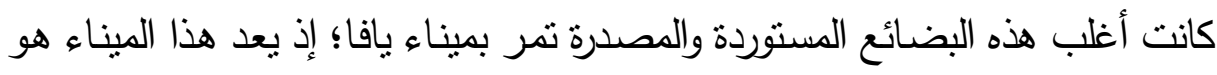

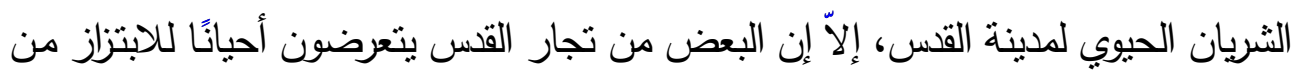

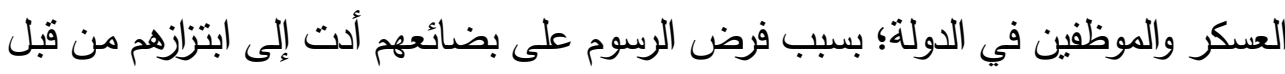

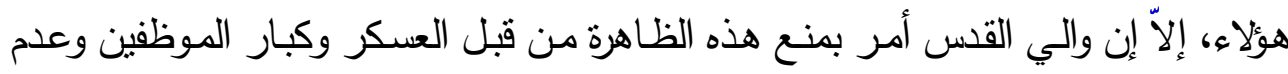
التعرض للتجار في مدينة القس الثريف (؟). ونلاحظ مما سبق أن الموقع الجغرافي لمدينة القس أسهم بشكل كبير في ازدهار التجارة سواء الداخلية أو الخارجية؛ كونها حلقة وصل بين مدن الثشام المختلفة؛ كما لا نغفل إنل دور استنباب الأمن في مدينة القس الذي أدى إلى انتعاش التجارة فيها.

( (1) محمد أحمد سليم: ناحية القس الثريف في القرن السادس عشر الميلادي، طا، عمان، 919 (م،

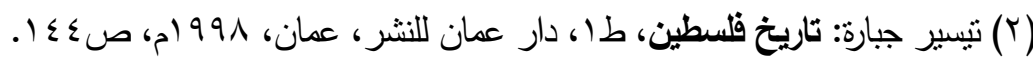




\section{الخاتمسة \\ توصلت من خلال بحثي هذا إلى جملة استتتاجات منها:}

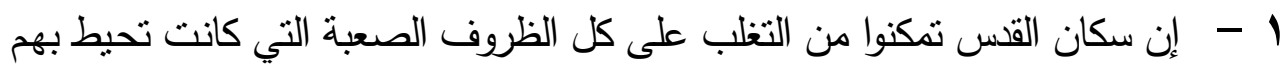

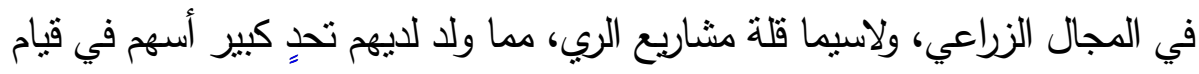

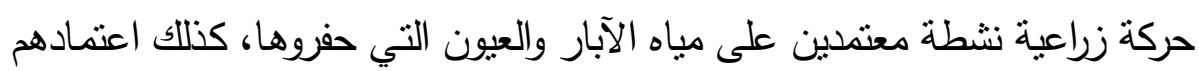
على الظروف المناخية السائدة في مدينتهم.

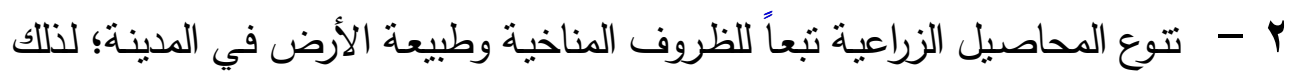

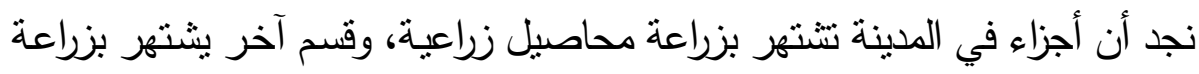
الفواكه بمختلف أنواعها.

ب - لم توّلِ السلطات العثمانية اهتمامًا بالجوانب الزراعيـة، مما أدى بالفلاحين للاعتماد على إمكانياتهم في تطوير شؤون زراعتهم.

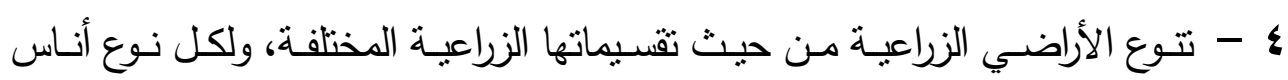
استنمروه بما يعود عليهم بالفائدة. ه - اعتمدت الصناعة على المواد الخام الزراعية الموجودة في المدينة في قيام العديد من لئن الحرف والصناعات المحلية التي كان يستخدمها السكان. 7 - أخذت الصناعة في جانب كبير منها طابع الصناعات الدينية التي يحتاجها السكان في أداء طقوسهم الدينية. العديد من الصناعات وجدت لسد الحاجة المحلية للسكان كصناعة الملابس أو المواد

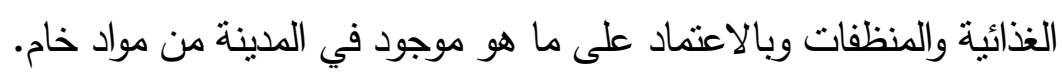

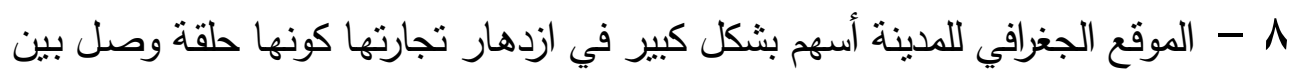
مدن الثام المختلفة. 9 - أسهر استتاب الأمن في المدينة والمدن المحيطة بها إلى انعانش عملية التجارة. 


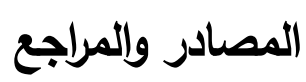

\author{
أولاً: المصادر:
}

ا. شكيب أرسـلان: تـاريخ الدولـة العثمانيـة، تحقيق: حسن السماحي سويدان، دار ابن

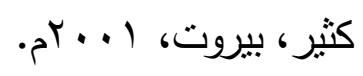

r. محد عبد الدنعم الحمبدي: الروض المعطار في خبر الأقطار، تحقيق: إحسان عباس،

$$
\text { مكتبة لبنان، بيروت، } 9 \text { أو م. }
$$

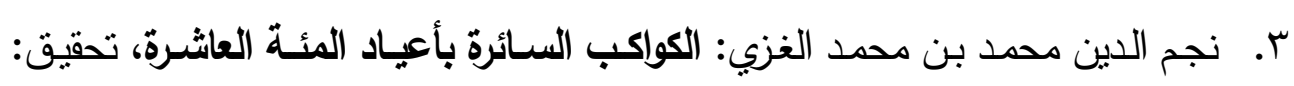

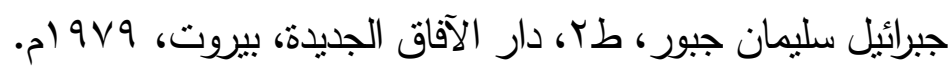

ثانيًا: المراجع العربية:

1. إحسان النمر : امتياز ولاية الثام في عهل آل عثمان، مطبعة الاقتصاد، نابلس، د.ت. r. أحمد جدي: نظام ملكية الأرض في فلسطين في العهل العثماني، المجلة التاريخية

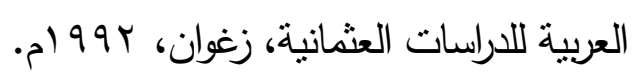

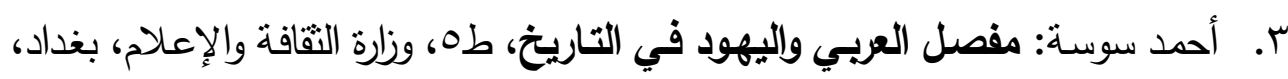

$$
\text { . } 1911
$$

ع. أحمد محمد الربايعة: الصناعات في فلسطين في العصور الحديثة، المؤتمر الدولي

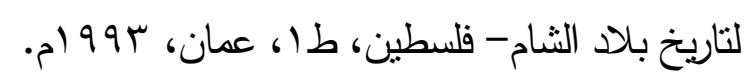

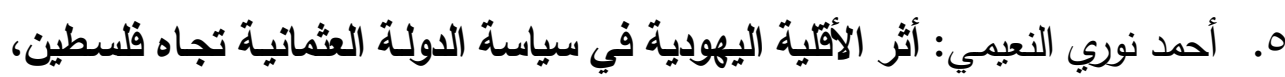

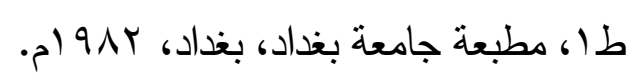

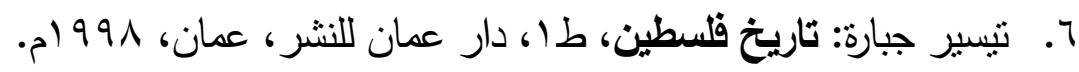

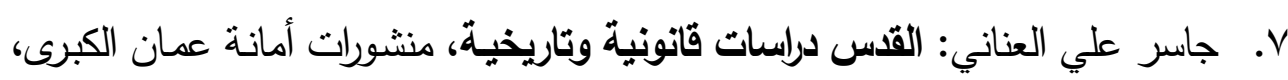

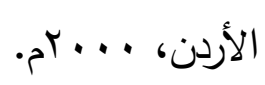

^. حبيب السيوفي: سوريا ولينان وفلسطين في القرن الثامن عثر كما وصفها مشـاهير

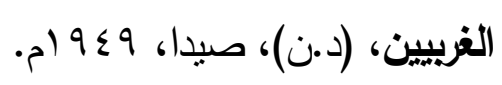




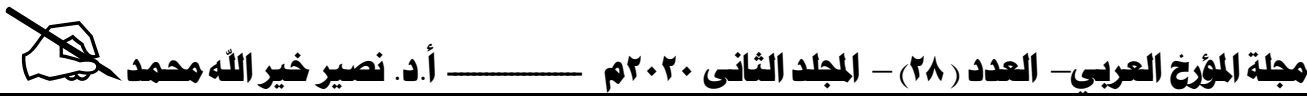
9. خالد تحسين علي: دراسـات في التتميسة وإلتكامسل الاقتصـادي العريـ، طب، مركز

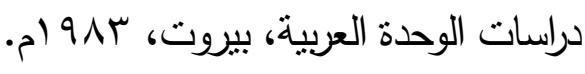

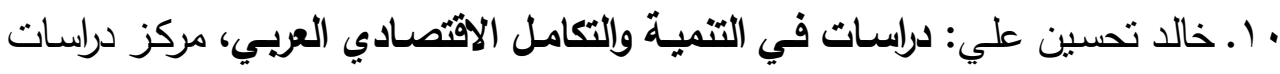

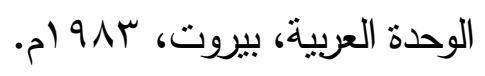

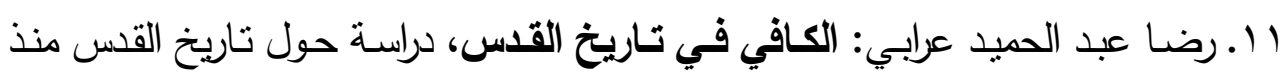

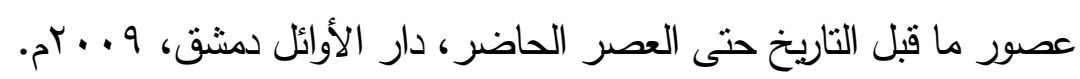

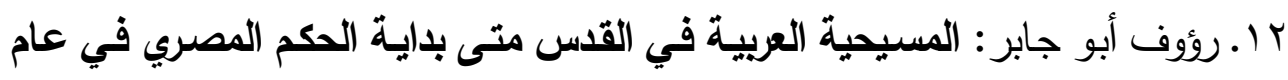

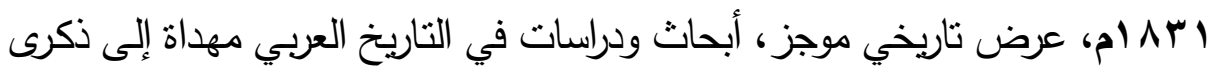

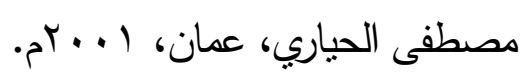

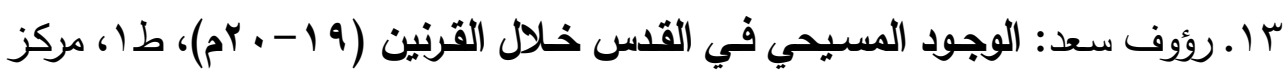

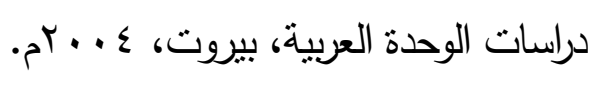

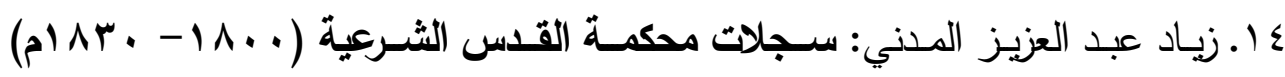

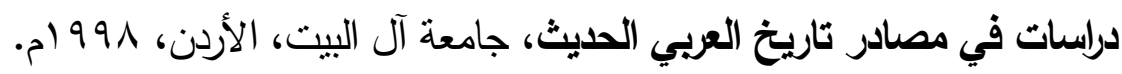

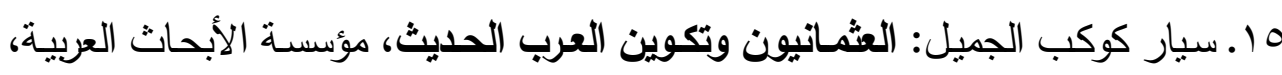

$$
\text { بيروت، } 919 \text { ام. }
$$

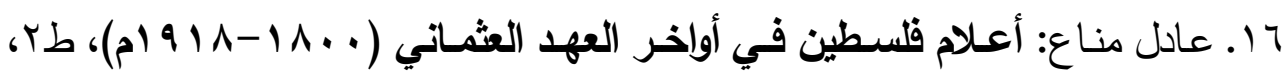

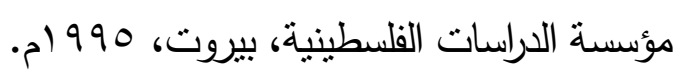

V V . عبد الرحيم عبد الرحمن: مصر وفلسطين في العصر العثماني من خـلال وثائق

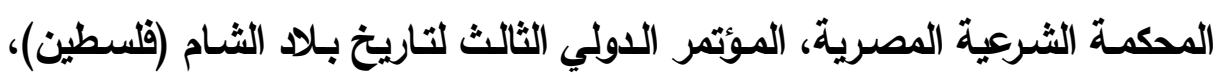

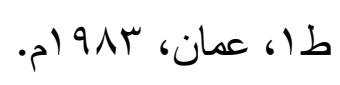

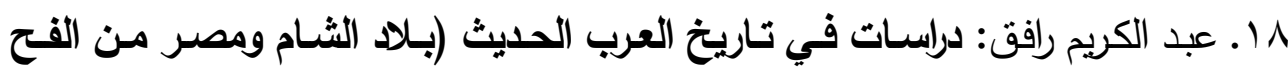

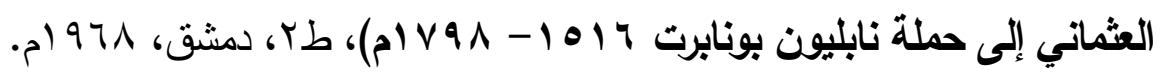

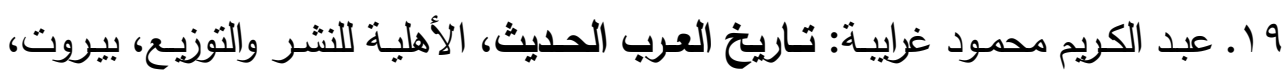




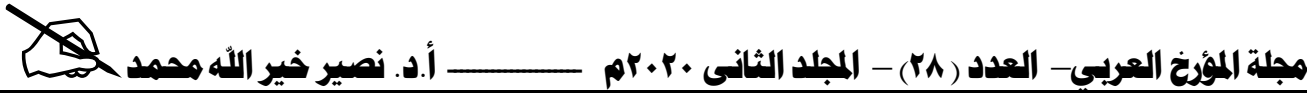

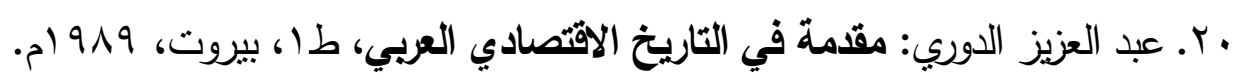

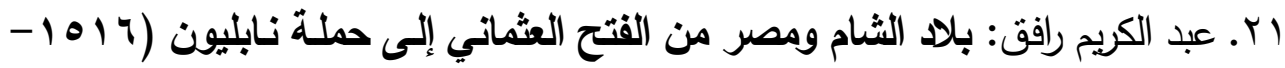

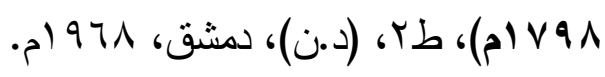

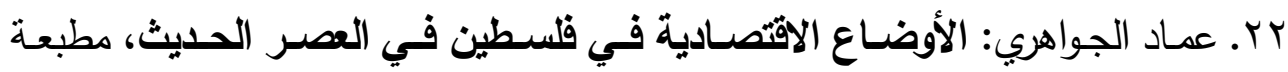

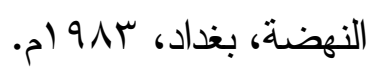

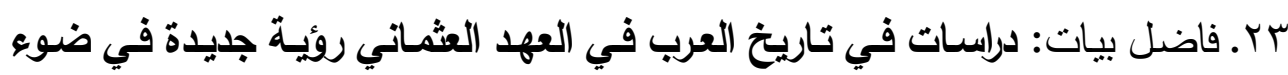

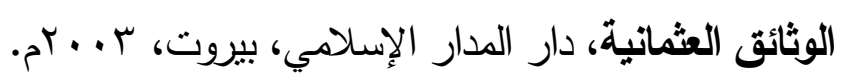

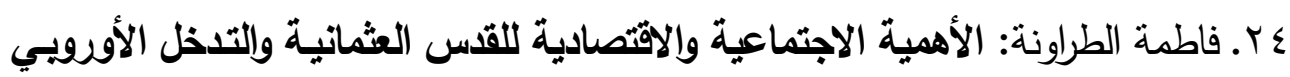

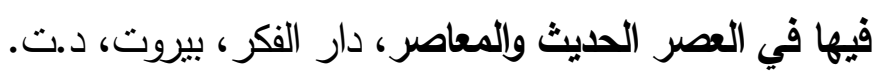

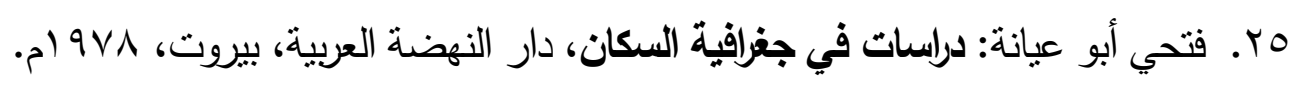

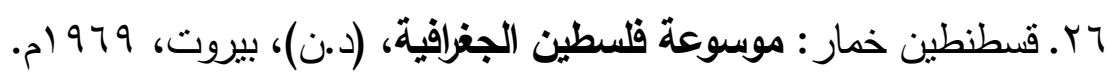

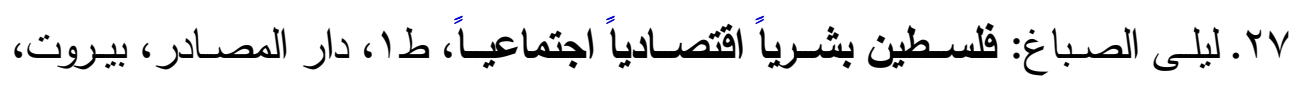
.01997

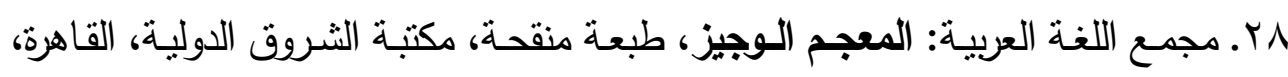
r tr

9r. مجموعة من الدفكرين العرب: دراسات في التنمية وإلتكامل الاقتصادي العربي، طץ،

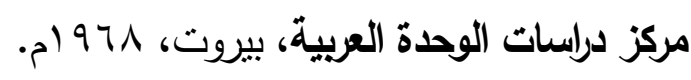
•r. محمد أحمد سليم: ناحية القدس الثريف في القرن السادس عثر المر الميلادي، طا،

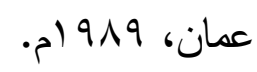

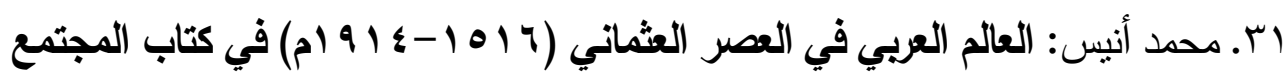

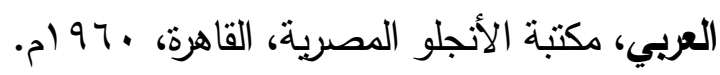

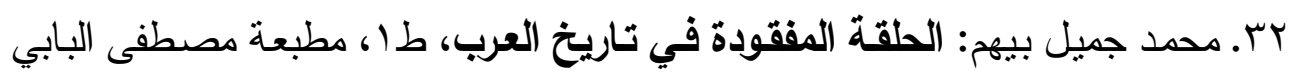

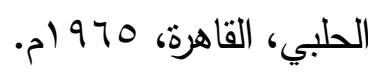




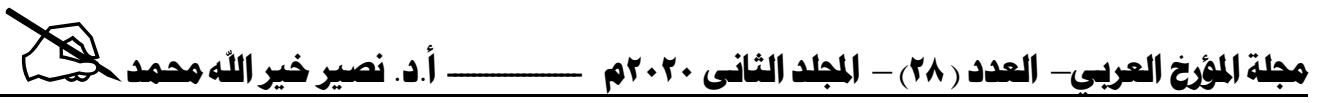

سب. محمد حسين محاسنة وآخرون: تاريخ مدينة القس في العهة العثماني، مكتبة الفلاح،

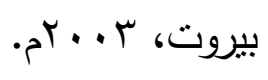

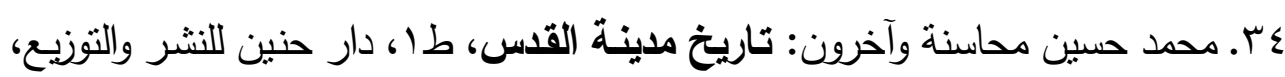

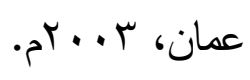

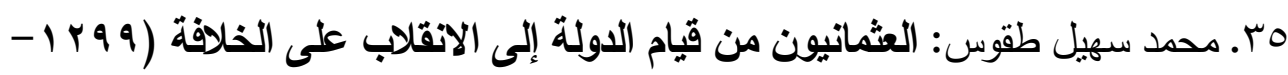

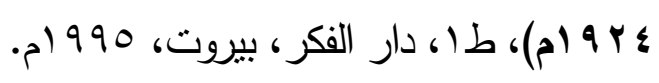

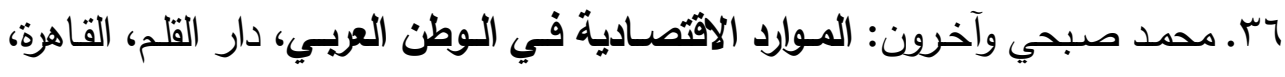

$$
\text { (ب) }
$$

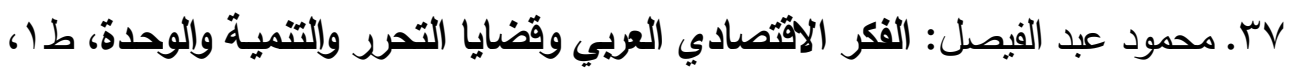

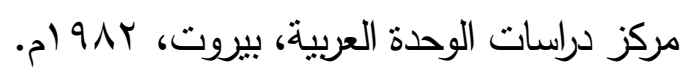

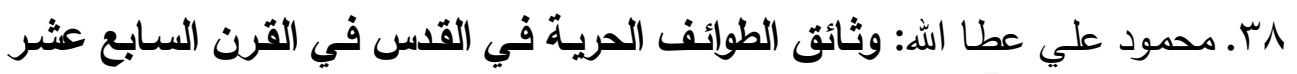

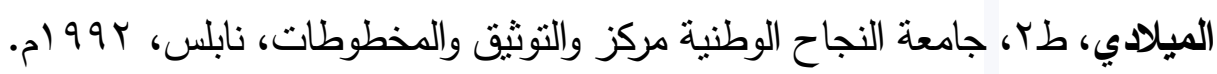

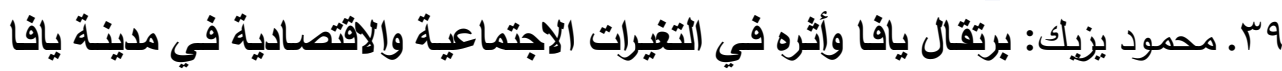

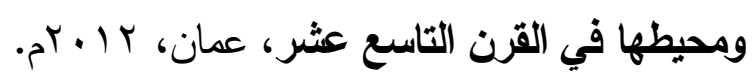

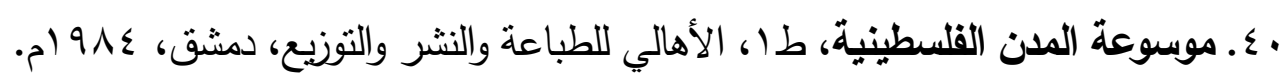

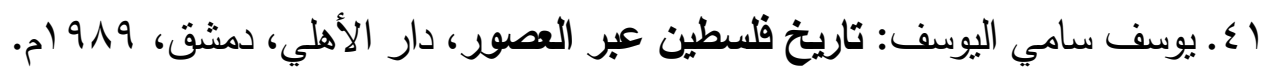

$$
\text { ثالثاً: الأبحاث والادراسات: }
$$

ا. . إبراهيم أبو رميس: الزراعة في القدس وكراها في القرن التاسع عثر، المؤتثر الدولي

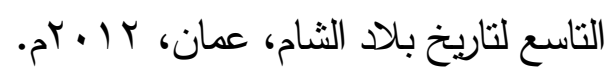

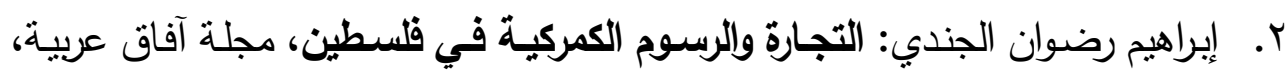

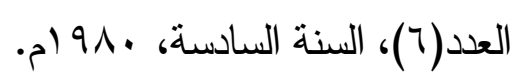

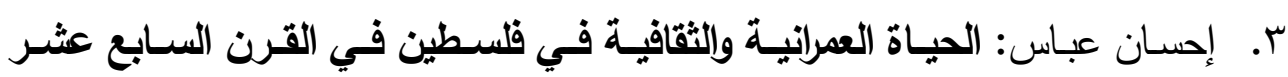

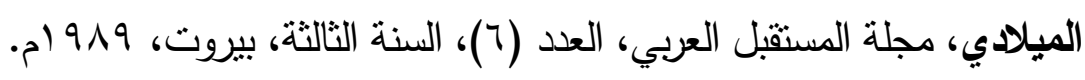




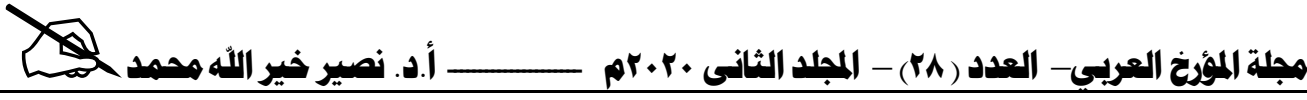

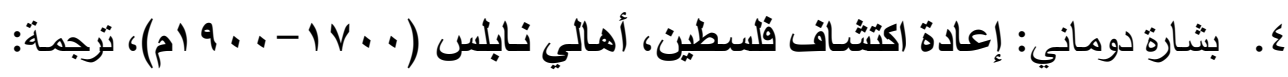

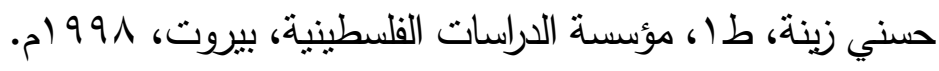

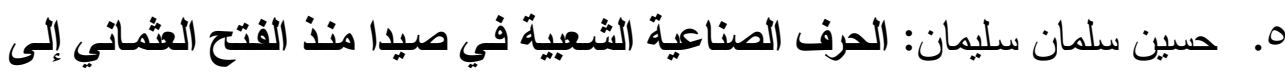

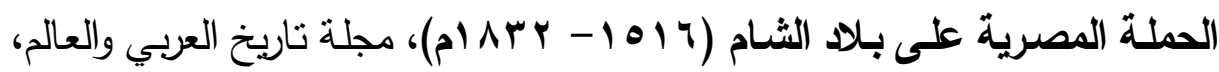

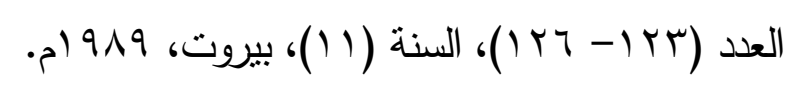

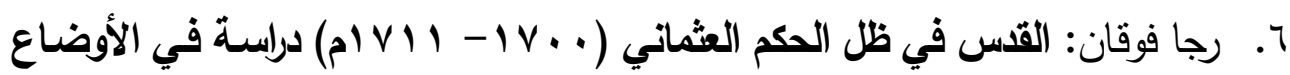

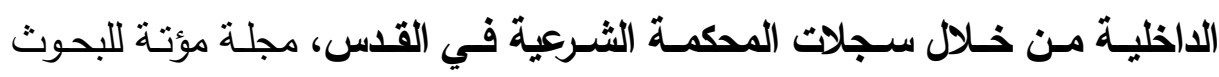

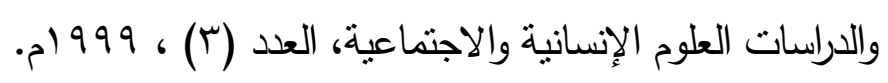

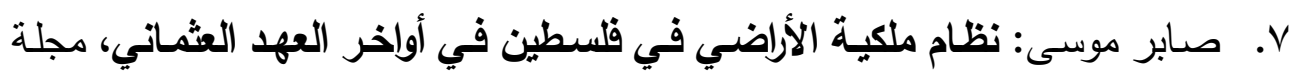

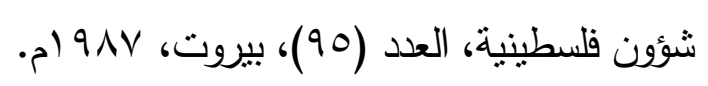

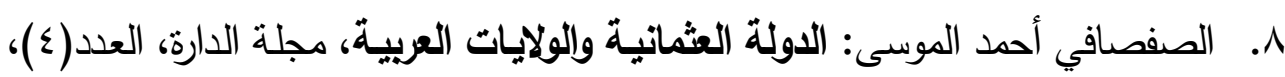

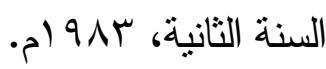

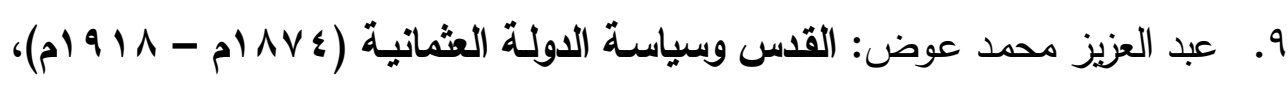

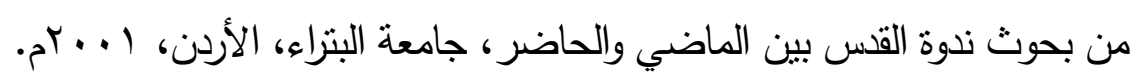

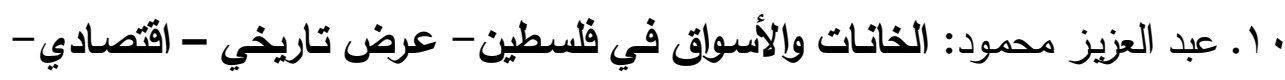

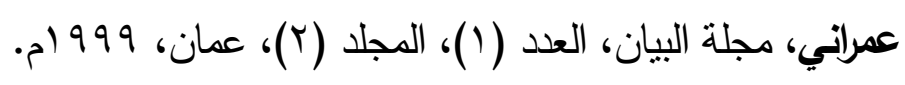

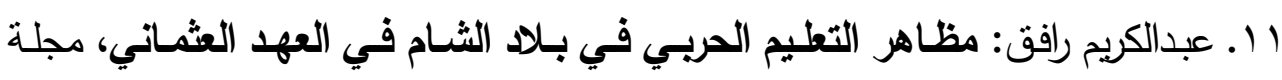

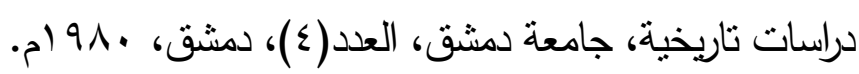

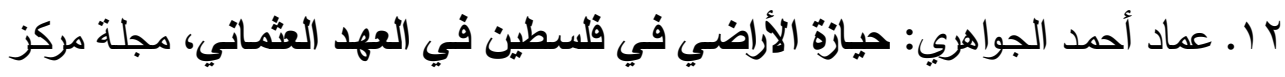

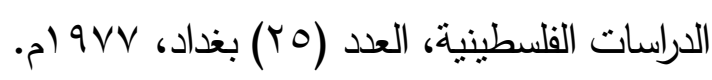

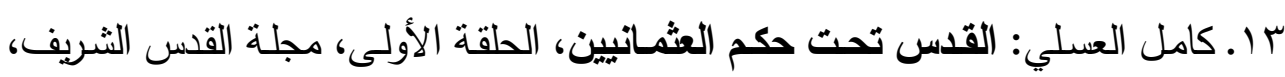

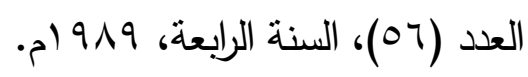

ـ ا ـ ليلى الصباغ: ملاحظات حول دراسة الاقتصاد العربي في العصر العثماني، ندوة الحياة

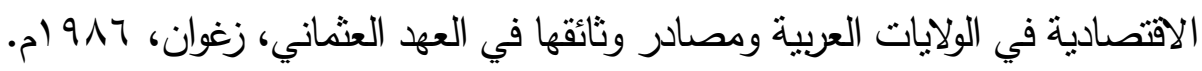




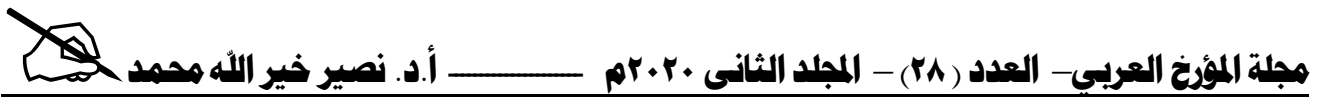
1 ـ مجلـة المهتدي: القــس تـاريخ وحضــارة ( . . . سق.م- 91 ام)، ط ا، بيـروت،

$$
\text { ... }
$$

7 ا ـ محمد سليمان: قانون التنظيمات العثماني وتملك اليهود في أرض فلسطين، مجلة

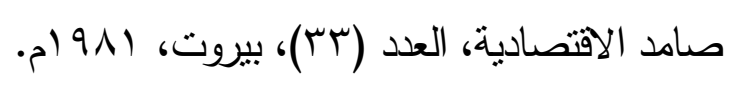

V ا ـ محمود عامر : الأوضـاع العامـة في القدس في ظل الإدارة العثمانية، مجلة دراسات

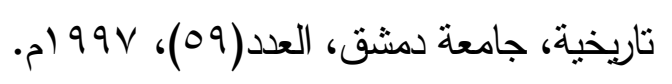

^1 ـ وليد العربض: المؤسسات العثمانية في القدس في الوثائق العثمانية، ندوة القدس،

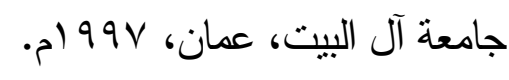

9 1. وليد العربض: تـاريخ الامتيـازات في الدولـة العثمانيـة وآثارهـا، مجلة دراسـات العلوم

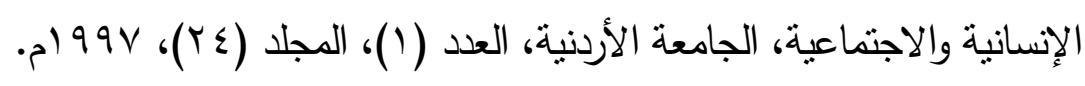

$$
\text { رابعًا: الكتب المترجمة: }
$$

ا. آ.ن. بولياك: الإقطاعية في مصر وسوريا وفلسطين ولبنـان، ترجمة: عاطف كربم،

$$
\text { مطبعة دار الكثوف، بيروت، بـ } 9 \text { ام. }
$$

r. أكمل الدين إحسان أوغلي: الدولة العثمانية تاريخ وحضارة، ترجمة: صالح سعداوي،

مركز الأبحاث للتاريخ والفنون التقافية والإسلامية، اسطنبول، 999 ام.

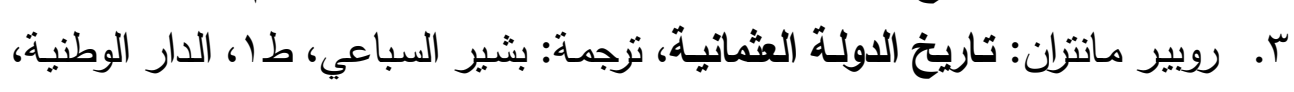

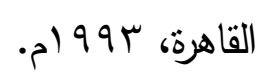

ع. سميح فرسون: فلسـين والقلسطينيون، ترجمة: عطا الله عبد الوهاب، طا (، مركز

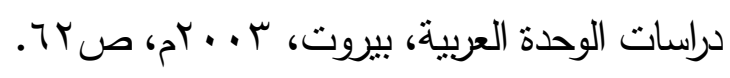

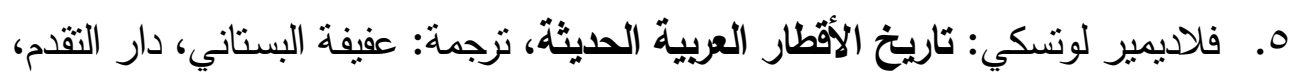

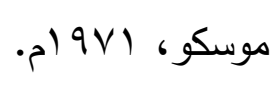

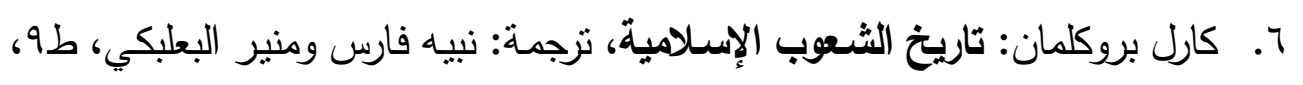

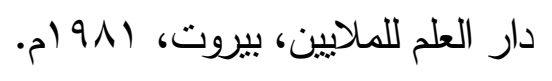




\section{>a}

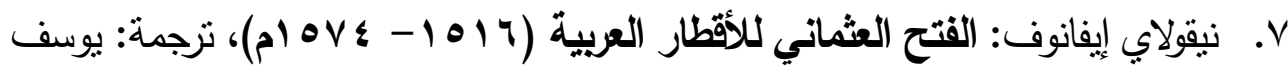

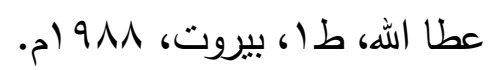

^. يلماز أوزتونا: تـاريخ الدولـة العثمانيـة، ترجمة: عدنان محمود سلمان، الدار العربية

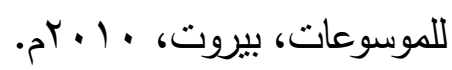

خامسًا: الرسائل الجامعية غير المنشورة:

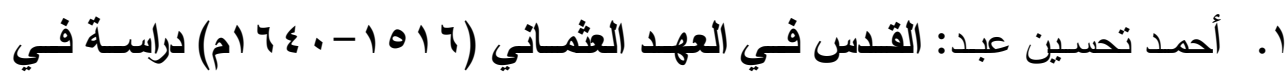
أوضـاعها الإداريـة والاقتصـادية والاجتماعيـة، رسالة ماجستير، كلية الآداب، جامعة

$$
\text { الموصل، ب +. . بم. }
$$

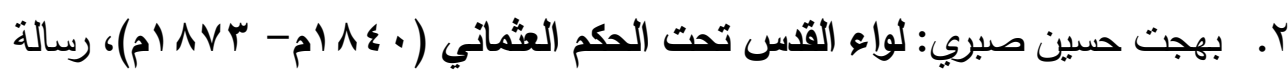

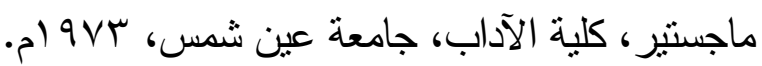

